By G. C. Bortleson, M. A. Jones, J. R. Evans, and P. P. Hearn, Jr.

U.S. GEOLOGICAL SURVEY

Open-File Report 90-363

Prepared in cooperation with the

COOS BAY-NORTH BEND WATER BOARD

Portland, Oregon

1992 
U.S. DEPARTMENT OF THE INTERIOR

MANUEL LUJAN, JR., Secretary

U.S. GEOLOGICAL SURVEY

Dallas L. Peck, Director

For additional information write to:

District Chief

U.S. Geological Survey 10615 S.E. Cherry Blossom Drive Portland, Oregon 97216
Copies of this report can be purchased from:

U.S. Geological Survey Books and Open-File Reports Section Federal Center, Box 25425

Denver, Colorado 80225 


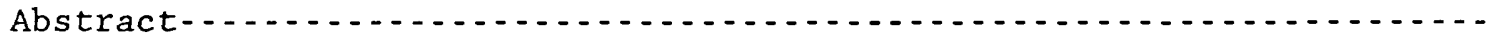

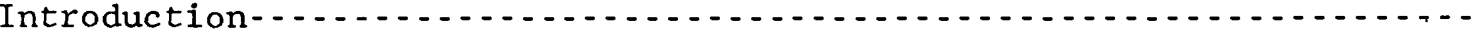

Purpose and scope-1.-1.2.

Methods of investigation-1..

We11-numbering system-1...

Acknowledgments $-\ldots \ldots \ldots$

Geochemical processes - $\ldots \ldots \ldots$

Geohydrologic setting-1..

Sand-dune physiography-1..

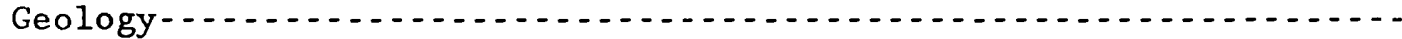

Stratigraphy of the dune-sand aquifer

Hydrology - . . . -

Geochemistry of iron in a dune-sand aquifer

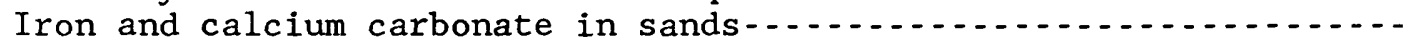

Dissolved iron concentrations in the shallow part of the aquifer-..

Dissolved iron concentrations in the deep part of the aquifer-....

Solubility-equilibrium calculations and stable isotope chemistry-.-

Influence of ground-water pumping on dissolved iron concentrations-...-

Dissolved iron concentrations in water from production wells......

Long-term changes in dissolved iron concentrations.............

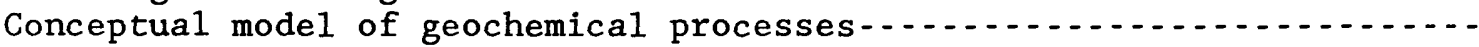

Summary and conclusions

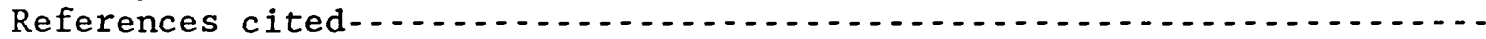

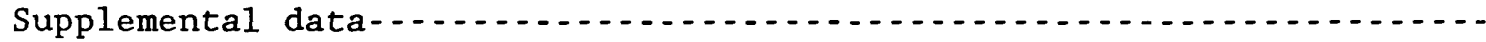

Site names for piezometers

Stable isotope reporting units

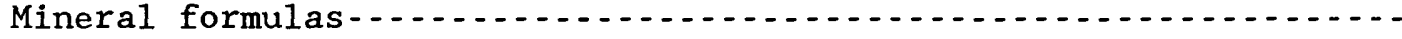

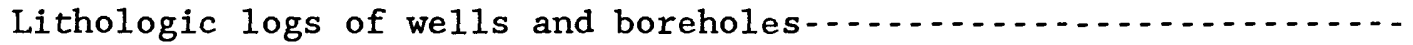




\section{ILLUSTRATIONS}

[Plate in back cover pocket]

Plate 1. Map showing showing location of piezometers and wells and aerial photograph with land cover of area north of Coos Bay, Oregon.

Page

Figure 1. Map showing study area near Coos Bay and North Bend, Oregon-- 3

2. Diagram showing well-numbering system-................. 5

3. Generalized schematic diagram of physiography of the

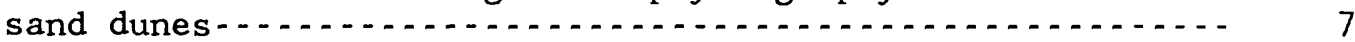

4. Geologic sections B-B', C-C', and D-D' $\ldots \ldots \ldots \ldots$

5. Map showing water-level contours of the dune-sand aquifer-... 10

6. Hydrogeologic section showing water movement through a section of the dune sand............................... 11

7. Graph showing vertical profile of dissolved iron concentration and $\mathrm{pH}$ at closely spaced intervals of depth in water

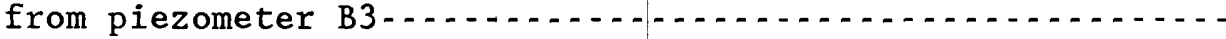

8. Photograph showing marine shell fragments in deep part of

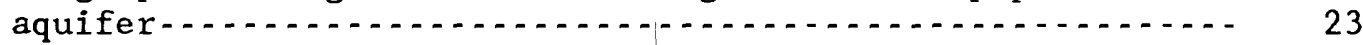

9. Scanning electron micrographs showing authigenic siderite

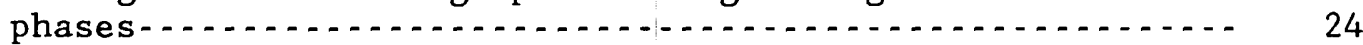

10. Scanning electron micrographs showing authigenic ferrous

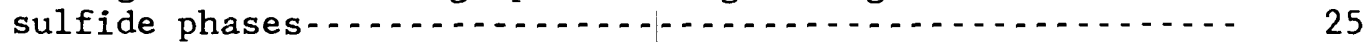

11-13. Graphs showing:

11. Vertical profile of calcite and siderite saturation index at closely spaced intervals of depth in water

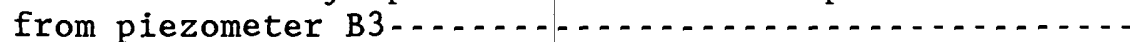

12. Relation between concentration of bicarbonate and $\delta$ carbon-13 in the deep part of the dune-sand

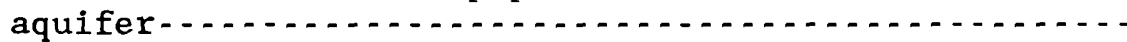

13. Relation between $\mathrm{pH}$ and $\delta$ carbon-13 in the deep part of the dune-sand aquifer......................

14. Schematic diagram showing dissolved iron concentration and $\mathrm{pH}$ in water from the dune-sand production wells.........

15. Diagram showing conceptual changes in ground-water flow patterns in an unconfined aquifer due to pumping.......

16-18. Graphs showing:

16. Relation between dissolved iron concentration and $\mathrm{pH}$ in water from the production wells and piezometers from the southern part of dunes................

17. Time trend of dissolved iron concentration in water

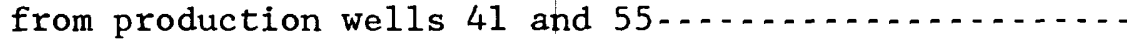

18. Diagram showing conceptual geochemical model of the

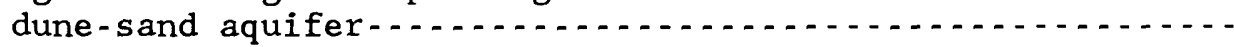


Table 1. Major chemical oxide composition of sands by X-ray fluorescence

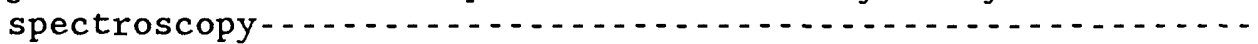

2. Total iron concentration in bulk sand sample and percent of total iron in acid ammonium oxalate extract......... 15

3. Calcium carbonate content of sands......... 16

4. Chemistry of shallow ground water beneath various land covers-- 17

5. Dissolved iron concentrations in shallow ground water beneath various land covers

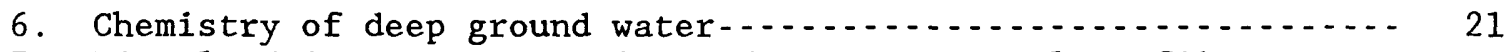

7. Dissolved iron concentration and $\mathrm{pH}$ in vertical profile at sites located in the northern part of the dunes-......... 27

8. Chemical data and saturation indices for shallow ground water-. 28

9. Chemical data and saturation indices for deep ground water.... 29

10. Chemical data and saturation indices for ground water from

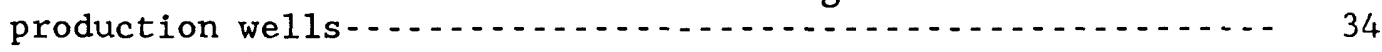

11. Production wells and percentage of well screen exposed to she11

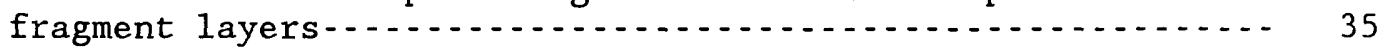

12. Occurrence of trends for dissolved iron concentrations in production wells using Seasonal Kendall test............ 38 


\begin{tabular}{|c|c|c|}
\hline Multiply & By & To obtain \\
\hline $\begin{array}{l}\text { inch (in.) } \\
\text { centimeter (cm) } \\
\text { foot (ft) } \\
\text { mile (mi) } \\
\text { square mile }\left(\mathrm{mi}^{2}\right) \\
\text { acre } \\
\text { million gallons per day } \\
\quad \text { (Mgal/d) }\end{array}$ & $\begin{array}{c}25.40 \\
0.0254 \\
0.3048 \\
1.609 \\
2.590 \\
4,047 \\
0.04381\end{array}$ & $\begin{array}{l}\text { millimeter }(\mathrm{mm}) \\
\text { meter }(\mathrm{m}) \\
\text { meter }(\mathrm{m}) \\
\text { kilometer }(\mathrm{km}) \\
\text { square kilometer }\left(\mathrm{km}^{2}\right) \\
\text { square meter }\left(\mathrm{m}^{2}\right) \\
\text { cubic meter per second } \\
\quad\left(\mathrm{m}^{3} / \mathrm{s}\right)\end{array}$ \\
\hline
\end{tabular}

Sea level: In this report "sea level" refers to the National Geodetic Vertical Datum of 1929 (NGVD of 1929)--a geodetic datum derived from a general adjustment of the first-order level nets of both the United States and Canada, formerly called Sea Level Datum of 1929.

degree Celsius $\left({ }^{\circ} \mathrm{C}\right)$ to degree Fahrenheit $\left({ }^{\circ} \mathrm{F}\right):{ }^{\circ} \mathrm{F}=1.8 \times{ }^{\circ} \mathrm{C}+32$

milligram per 1iter $(\mathrm{mg} / \mathrm{L}) \times 1,000=\operatorname{micrograms} \operatorname{per} 1$ iter $(\mu \mathrm{g} / \mathrm{L})$ 
SOURCES AND CAUSES OF DISSOLVED IRON IN

WATER FROM A DUNE-SAND AQUIFER NEAR

COOS BAY AND NORTH BEND, OREGON

G. C. Bortleson, M. A. Jones, J. R. Evans, and P. P. Hearn, Jr.

\section{ABSTRACT}

Geochemical processes controlling dissolved iron concentrations were studied in a dune-sand aquifer used for municipal and industrial water supply near Coos Bay and North Bend, Oregon. Elevated concentrations of dissolved organic compounds and carbon dioxide produced from the root zone and litter of lodgepole pine forest ( $P$ inus contorta) increase the capacity of shallow ground water to dissolve iron-bearing minerals. Dissolved iron concentrations are largest in shallow ground water that had infiltrated areas of forest and smallest in water that had infiltrated bare sand. Forest cover makes up about 50 percent of the dune surface. Shallow water beneath this forested land cover commonly has been found to contain 2,500 to 30,000 micrograms per liter of dissolved iron. In adjacent bare sand areas, the dissolved iron concentration averages about 300 micrograms per liter.

In contrast to shallow ground water beneath forest areas, dissolved iron concentrations in water from most deeper parts of the aquifer are small. Water in the deeper part of the aquifer is prevented from attaining large concentrations of iron by the dissolution of calcium carbonate in the form of marine shell fragments. The dissolution of calcium carbonate raises the carbonate-bicarbonate concentration of water and causes ferrous iron to precipitate as siderite (ferrous carbonate). Observed $\mathrm{pH}$ values in the deeper sections of the aquifer containing shell fragments are near or above $\mathrm{pH} 8.0$, and ferrous iron concentrations are commonly less than 10 micrograms per liter.

Twenty production wells are located in the southern part of the dunes where lodgepole pine forest covers much of the dune area and where a general abundance of marine shell fragments exists in the deeper part of the aquifer. Water pumped from the production wells is a mixture of water with relatively small concentrations of iron from the lower part of the aquifer and large concentrations of iron from the upper part of the aquifer. The median iron concentration for all production wells studied was 4,500 micrograms per liter, and the median $\mathrm{pH}$ was 7.4. Mixing of deep with shallow water is indicated by lower $\mathrm{pH}$ values and larger iron concentrations in the water from most of the production wells compared to water from deep piezometers.

Time-trend analysis of dissolved iron concentration in water from production wells indicates that in a 20- to 25-year operational history, a significant increase in iron has occurred for 12 of the 20 wells. The progressive encroachment of lodgepole pine and other vegetation on the sand dune surface is postulated as an explanation for the increased concentration of dissolved iron in water from production wells. 


\section{INTRODUCTION}

The largest concentration of ground-water pumpage from dune sand along the Oregon coast is near Coos Bay and North Bend (fig. 1). These twin cities operate 20 production wells that collectively yield about $5 \mathrm{Mgal} / \mathrm{d}$ (million gallons per day) for municipal and industrial water supplies. The dune sand is highly permeable and absorbs and stores a high percentage of the average annual 63 inches of rain that falls on the dunes. The water in this dune sand represents a substantial source of water supply in addition to surface-water sources. Demands for water supply have increased in Coos Bay and North Bend where different sources for additional water for a wood pulpmill are being evaluated. Plans for increased pumping from dune-sand aquifers, however, depend in part on the quality of water. Elevated iron concentrations are a common complaint of ground-water users in localities along the Oregon coast who withdraw water from dune sand (Christensen and Rosentha1, 1982; Frank, 1970; Hampton, 1963; and Brown and Newcomb, 1963). Iron concentrations of 3,000 to $6,000 \mathrm{\mu g} / \mathrm{L}$ (micrograms per liter) are common in waters of production we1ls near Coos Bay (Dobberpuhl and others, 1985).

Water having large concentrations of iron requires removal or mixing with other water to render it suitable for most uses. Large concentrations of iron can cause water to be highly colored, and the colloidal nature of ferric hydroxide can result in increased turbidity. Large concentrations of iron also can cause staining and encrustation. A secondary problem that can occur as a consequence of large iron concentrations is the development of iron bacteria in the distribution system. This leads to the clogging of pipelines and the production of odors.

\section{Purpose and Scope}

The purpose of this report is to present the results of a study that describes the sources and causes of dissolved iron in the dune-sand aquifer and from water pumped by production wells. Data on chemistry of the ground water, mineralogy of the aquifer materials, and ground-water flow were collected to determine most probable geochemical reactions. Major controls in geochemical processes of iron are identified in the undisturbed and pumped parts of the aquifer. These controls can be incorporated into a new wellfield design. Knowledge of factors influencing dissolved iron concentrations can be used to make rational decisions to locate wells where large iron concentrations are less likely to be encountered.

\section{Methods of Investigation}

Samples of shallow and deep ground water were collected from piezometers between January 1986 and July 1988. Most of the shallow piezometers were screened 4 to 6 feet below the water table, and some piezometers were screened 13 to 18 feet below. The deep piezometers were screened at depths greater than 50 feet below the water table, and most of them at depths greater than 100 feet below. The lengths of the screened intervals for the shallow and deep piezometers were 2 and 3 feet, respectively. The location of all piezometers sampled is shown on plate 1 . 


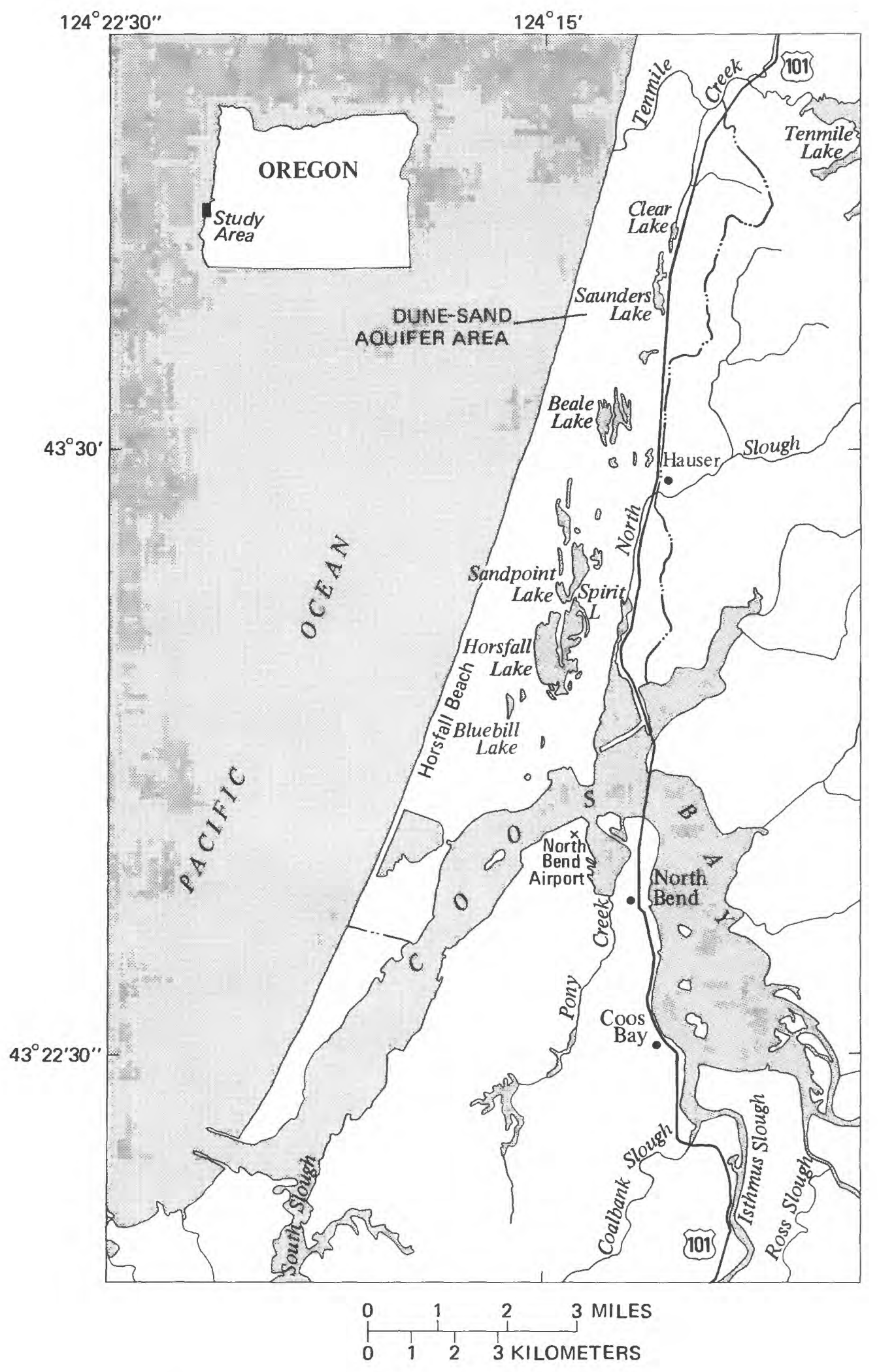

Figure 1.--Study area near Coos Bay and North Bend, Oregon. 
The piezometers were sampled using either a centrifugal or submersible pump. Water from the piezometers was pumped at about one-half to threefourths of a gallon per minute. Slow rates of pumping were used to minimize introducing vertical fluxes much beyond the screened interval. The discharge line was connected directly to a flow-through chamber that accommodated probes for the simultaneous measurement of $\mathrm{pH}$ and temperature. Stabilization of $\mathrm{pH}$ and temperature usually was achieved within 10 minutes. After stable readings of these field measurements were attained, the source water was diverted past the flow-through chamber for collection of filtered and raw-water samples. Concentrations of dissolved oxygen were determined in the field by Winkler titration, and bicarbonate was determined by incremental titration. The source water was then allowed to pass, isolated from the atmosphere, through a 0.1 -micron pore-size cellulose filter for field determination of iron by the bipyridine method (Skougstad and others, 1979, p. 387). Dissolved ferrous iron was complexed immediately by injecting a sample of water from a syringe unexposed to the atmosphere into a solution of bipyridine reagent and analyzed within 2-10 hours. The concentration of dissolved ferric plus ferrous iron was determined by converting ferric iron to ferrous with hydroxylamine hydrochloride and adding bipyridine to develop a colored complex. Dissolved ferric iron was then calculated by subtracting the dissolved ferrous concentration from the dissolved ferric plus ferrous iron concentration.

Major ions, dissolved organic carbon, and trace elements were analyzed by the U.S. Geological Survey laboratory in Arvada, Colorado, using standard procedures (Skougstad and others, 1979). Stable isotope ratios of carbon were determined by L. D. White, U.S. Geological Survey, Water Resources Division, Menlo Park, California. Iron analyses of water from the production wells for the period 1971 to 1987 were done by laboratory personnel of the North BendCoos Bay Water Board. Water samples collected from piezometers installed at closely spaced vertical intervals were analyzed by the U.S. Geological Survey during 1978 to 1982. Much of the water-quality data collected during this period is reported by Dobberpuh1 and others (1985).

Samples of sand grains were analyzed by the U.S. Geological Survey laboratories in Reston, Va., using a scanning electron microscope (SEM) equipped with an energy dispersive X-ray fluorescence detector (EDXRF). The samples were prepared by (1) imbedding the sand grains in epoxy and then polishing to expose grain surfaces and (2) sprinkling grains onto mounts coated with carbon adhesive. The first method produced a smooth surface for chemical analysis by EDXRF, and allowed grains to be examined for alteration halos or coatings. The second method allowed grains to be examined for surface textures. Sand samples were also analyzed by X-ray fluorescence to determine their major oxide composition and by chemical methods to determine the percentage of extractable iron and calcium carbonate.

\section{We11-Numbering System}

The we11-location numbering system used in this report is shown in figure 2. We11s in Oregon are identified by township, range, and section. We11 24S/13W-21CCD01 indicates successively, the township (T.24 S.), and range (R.13 W.), and section (21) within the township. The first letter C denotes the SW quarter section (160 acres); the second letter $C$, the quarter-quarter section (40 acres); and the third letter D, the SE quarter-quarter-quarter section (10 acres). Where two or more wells are in the same 10-acre 


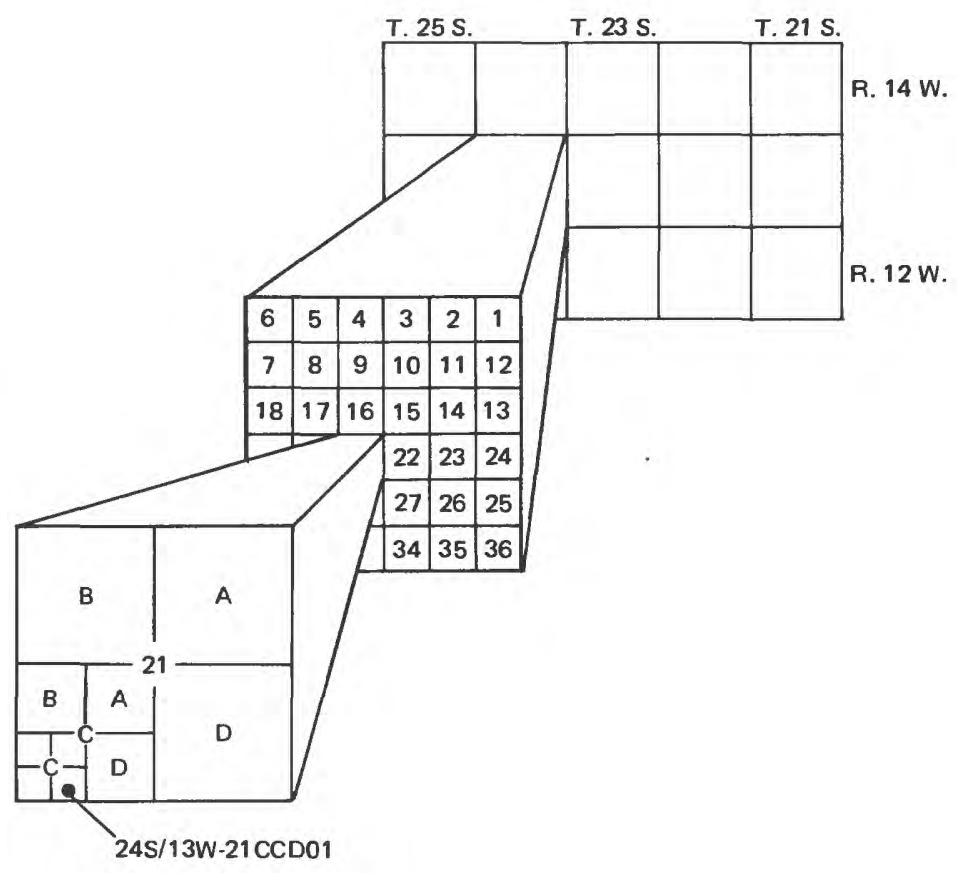

Figure 2.--Well-numbering system.

subdivision, sequential numbers (01) are added after the third letter. Well numbers and site names for all wells sampled are shown on plate 1 . The map site names, which contain both alpha and numeric combinations, were assigned during the project to serve as an abbreviated scheme for identifying individual wells on the map.

\section{Acknowledgments}

Acknowledgment is given to the staff of the Coos Bay-North Bend Water Board for advice and assistance. These persons include Phil Matson, general manager; King Phelps, engineer; and Voneal Hadden, water treatment operator. Report reviews and helpful suggestions during the study were provided by Dr. John F. Mann, Jr., ground-water consultant to the Water Board, and by Calvin W. Heckard, consultant to the Board, former general manager, and chief engineer. The U.S. Forest Service extended permission and cooperation for test drilling within the National Forest.

\section{GEOCHEMICAL PROCESSES}

Data collected in a dune-sand aquifer near Coos Bay and North Bend, Oreg., showed that dissolved iron concentrations were largest in shallow water that had infiltrated forest-covered sand, and smallest in water that had infiltrated bare sand (Bortleson and others, 1989). About 50 percent of the dune-sand aquifer is covered by lodgepole pine (Pinus Contorta) forest.

In forest-covered areas, large concentrations of dissolved organic compounds are leached into the ground water, and carbonic acid is formed as abundant carbon dioxide is released to the ground water by root respiration and decay of organic matter. These plant-induced processes greatly increase the capacity of shallow ground water to dissolve iron-bearing minerals. These findings indicate that natural processes, involving forest vegetation, are 
responsible for chemical weathering and release of iron from sand dunes. The large iron concentrations are not anthropogenic except in the sense that a rapid expansion of lodgepole pine forest may have been induced by man.

Aerial photographs taken in 1942, 1961, and 1984 show that the lodgepole pine forest near Coos Bay and North Bend has progressively encroached the coastal deflation plain and other parts of the sand dune surface (Bortleson and others, 1989). One explanation for the recent increase in forest cover is the stabilization of the sand dune by European beach grass, imported by man at the turn of the century (Wiedemann, 1984). This plant has stabilized the foredune ridge to the extent that it is rarely breached by the ocean. In addition to stabilizing the foredune, beach grass has stabilized other parts of the sand dune, allowing the lodgepole pine seedlings to grow without being buried and killed by shifting sands.

In contrast to shallow ground water underneath forested areas, results of limited sampling indicated iron concentrations in the deep parts of the dunesand aquifer are less than $500 \mu \mathrm{g} / \mathrm{L}$ and $\mathrm{pH}$ values are near or above $\mathrm{pH} 8.0$ (Bortleson and others, 1989). These waters are prevented from attaining large concentrations of iron by dissolution of marine shell fragments (calcium carbonate). The slow dissolution of shell fragments raises carbonatebicarbonate concentration and $\mathrm{pH}$ of infiltrating ground water and causes iron to precipitate as siderite (ferrous carbonate).

The shells appear to exist primarily in the deeper part of the HolocenePleistocene sands. About 9,000 years ago, the sea level began to rise rapidly with the melting of continental glaciers, and relatively shell-free sands were then deposited on a new terrace.

\section{GEOHYDROLOGIC SETTING}

The study area is located between Coos Bay and Tenmile Creek in southwestern Oregon (fig. 1), is about 13 miles long, averages about 1.5 miles wide, and includes an area of about $24 \mathrm{mi}^{2}$. The sand dune covers about $19.5 \mathrm{mi}^{2}$ of the study area (fig. 1), and is a small part of a discontinuous series of dune sand extending the length of the Oregon coast.

\section{Sand Dune Physiography}

The dune sand are a complex mosaic of many landforms caused by the interaction of sand, wind, water, and vegetation. A generalized schematic diagram showing sand dune physiography is shown in figure 3. Adjacent and parallel to the beach is a narrow (approximately 200 feet wide) ridge or foredune produced by offshore winds. Plants on this 15- to 20-foot-high foredune are permanently established above the high-tide line. European beach grass has stabilized the foredune ridge; thus, it is rarely breached by the ocean (Wiedemann, 1984).

Landward of the foredune is a coastal deflation plain up to one-half mile wide that is essentially continuous for the length of the project area. This coastal deflation plain was formed by wind efoding the sand surface nearly to the water table. The wet sand surface is resistant to further erosion, allowing vegetation, mostly lodgepole pine, to become established and grow rapidly. 


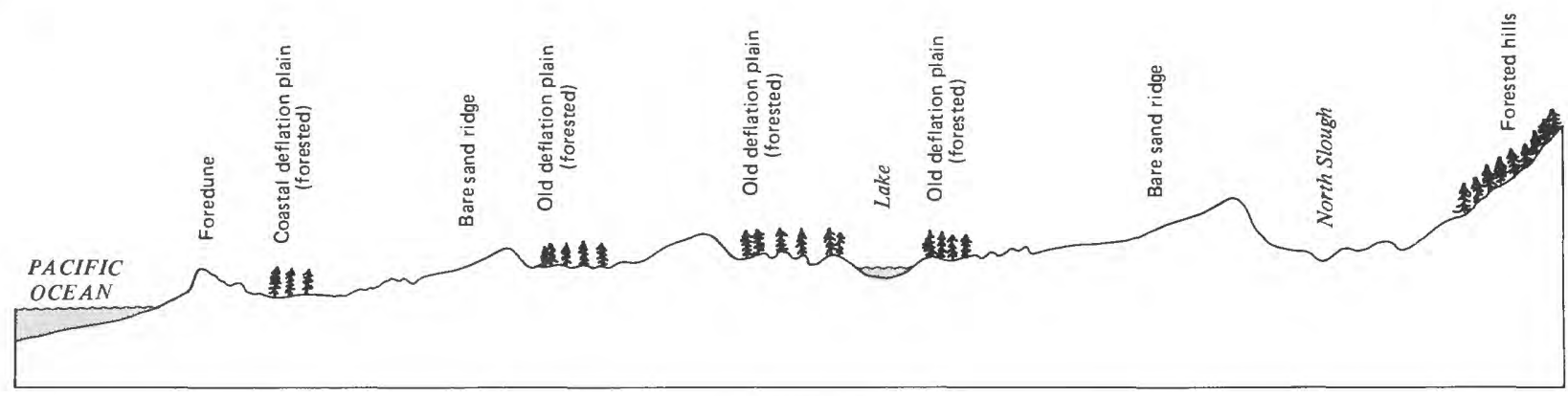

NOT TO SCALE

Figure 3.--Generalized schematic diagram of physiography of the sand dunes.

East of the coastal deflation plain are irregular bare sand ridges reaching elevations greater than 100 feet above sea level. These ridges are composed of loose sand that is subject to shifting by winds. Eastward of these ridges is another deflation plain, which is older and generally less densely covered by lodgepole pine than the coastal deflation plain (fig. 3 ). Typically, the older plain lies 15 to 30 feet above sea level and contains a string of north-south trending lakes lying in a depression. The land surrounding the lakes is mostly forested. Along most of the north-south axis of the project area, a ridge of bare sand occurs on the eastern edge of the sand dune, adjacent to the forested hills of older marine deposits.

\section{$\underline{\text { Geology }}$}

The dune-sand aquifer is composed of loosely compacted and uncemented fine-to-medium grain sand of predominantly Holocene age. The sand dunes are about 160 feet thick in the south along the coast. At depth, the windblown sand probably is interbedded with marine sand that was deposited in the littoral zone when the sea was at lower levels. Wood fragments in drill-hole cuttings near the base of the sand aquifer near the coast in the southern part of the dunes indicate an age of $28,000 \pm 800$ years by carbon-14 dating (Magaritz and Luzier, 1985, p. 2,516).

The dune-sand aquifer is underlain locally by Pleistocene-age marine deposits (Robison, 1973), but is most commonly underlain by fine-grained Tertiary deposits of sandstone, siltstone, and mudstone of late Eocene age (Brown and Newcomb, 1963; Baldwin, 1964). The Pleistocene deposits where present are underlain by the fine-grained Tertiary deposits. The Pleistocene marine deposits are exposed predominantly in the northeastern part of the study area. The marine deposits of Pleistocene and late Eocene age have not been mapped in detail; therefore, these two deposits are considered a single unit and is referred to as "Pleistocene and fine-grained Tertiary deposits."

\section{Stratigraphy of the Dune-Sand Aquifer}

To correlate observed dissolved iron concentrations with the general abundance of shell-containing sands, the distribution of shell fragments was determined from lithologic logs of 50 wells (supplemental data; end of report). The predominant sediment deposits are sand or shell fragments mixed with sand. Shell fragments are commonly observed in the fine-grained Tertiary 
deposits underlying the sand aquifer. Thin layers of fine-grain sediment such as silt and clay or silt and clay mixed with sand are recorded for some lithologic logs.

The geologic sections shown in figure 4 indicate the variability that exists in the deposition of shell material. In the southern part of the dunes, geologic sections $C^{-C^{\prime}}$ and $\mathrm{D}^{-\mathrm{D}^{\prime}}$ show relatively thick and sometimes continuous layers of shell fragments mixed with sand. In general, there is a decrease in shell material northward, as shown by geologic section B-B' (fig. 4) and lithologic logs of Radar Cluster G9, Hauser no. 1, W60, and other lithologic logs in the northern part of the sand dunes (supplemental data). The thickness of the sand aquifer also decreases from south to north. For example, near the coast in the southern part of the dunes, the altitude of the base of the sand aquifer is about -170 feet (fig. 4), and near the coast in the northern part of the dunes it is about -110 feet (piezometer 203; see pl. 1 for location).
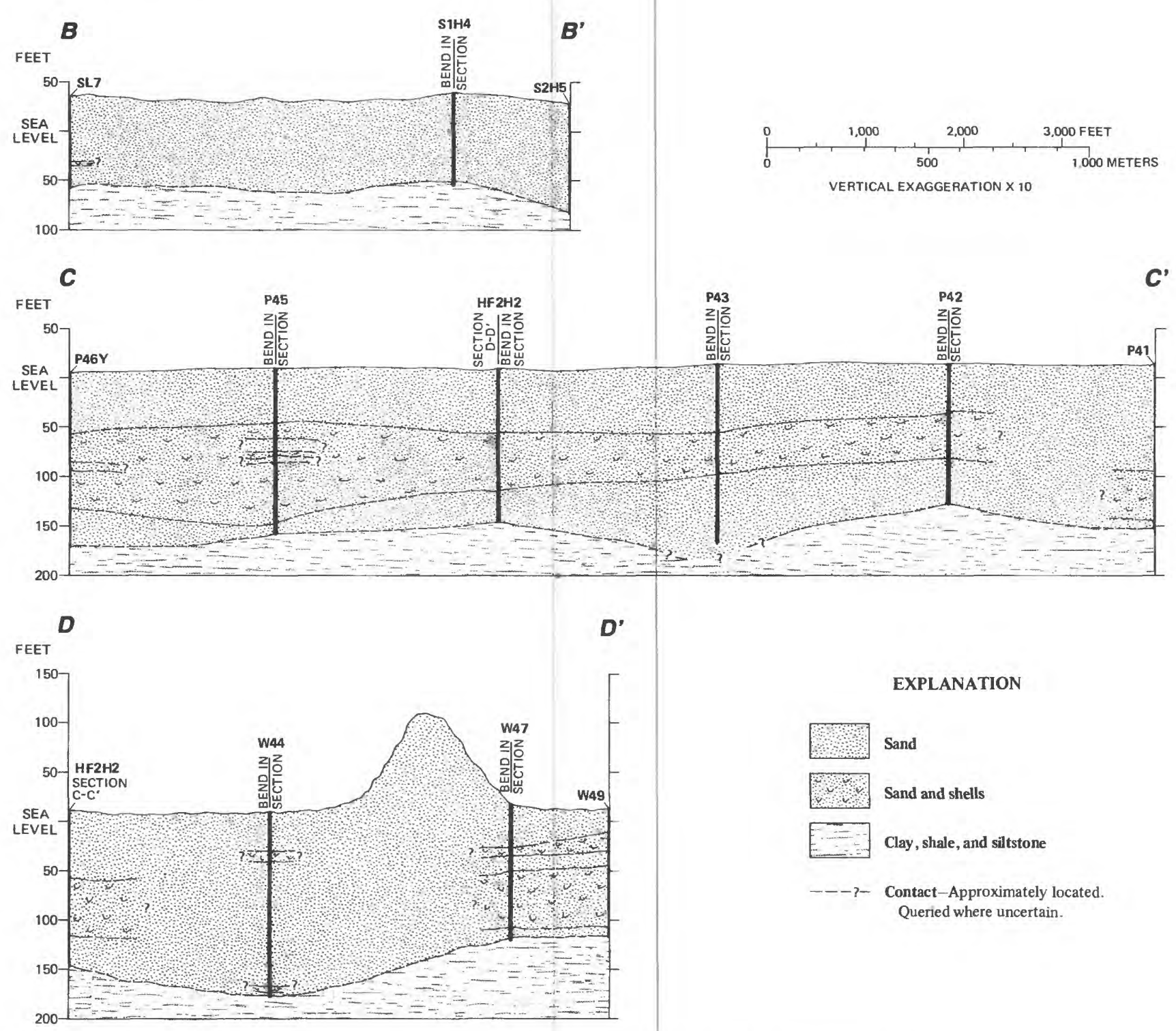

EXPLANATION
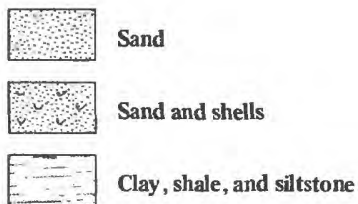

-- - Contact-Approximately located. Queried where uncertain.

Figure 4.--Geologic sections B-B', C-C', and D-D', shown on plate 1 . 
Shell fragments are most abundant from the base of sand aquifer to -25 feet elevation. The thickness of sands containing shell fragments ranges from a fraction of a foot to about 70 feet. From -25 feet elevation to sea level, only a few wells penetrated sands containing shell fragments, and above sea level, shel1 fragments were not found (supplemental data).

In the southern part of the dunes, where shell fragments are generally abundant, there are areas of local thinning of shell fragments (see fig. 4). In the northern part of the dunes, there are fewer well logs to determine the spatial distribution of shell fragments in sands. However, the limited number of we11 logs indicates that the shell material is relatively abundant along the entire coast and sparse or nonexistent in the inland part of the northern dunes (fig. 4). For example, drill cuttings from piezometers S2H5 and S1H4 located inland from the coast indicated no sands containing shell fragments, and cuttings from piezometer SL5 near the coast (see p1. 1 for location) show a layer of sand and shells about 50 feet thick overlying the fine-grained Tertiary deposits.

\section{Hydrology}

Most precipitation infiltrates rapidly into the dune-sand aquifer; however, some loss to surface runoff occurs during the wet season from November through March. Lakes and seasonal ponds are a surface expression of the water table (Robison, 1973). Discharge from the aquifer occurs by evapotranspiration, pumping from wells, and subsurface outflow to the ocean and surrounding saltwater bodies of North Slough and Coos Bay.

Ground water flows in the general direction of decreasing water levels. Consequently, flow directions can be inferred from water-level maps. The water-level lines of equal altitude in figure 5 show that the general flow of water in the dune-sand aquifer is westward toward the Pacific Ocean, southward toward Coos Bay, and eastward toward North Slough. Horizontal ground-water gradients north of Beale Lake are toward the Pacific Ocean and are as much as 50 feet per mile from east to west. South of Beale Lake, the ground water flows eastward toward North Slough, westward toward the Pacific Ocean, and southward through or beneath Horsfall and Spirit Lakes toward Coos Bay. Age determinations of deep waters by carbon-14 at sites S4H3 and P45 (see p1. 1 for location) indicate that the ground water circulates rapidly. Deep water contained 100-percent modern carbon, indicating ages no greater than a few hundred years, and tritium dating of the waters indicate probable average ages to be tens of years. Calculated residence time based on hydraulic properties are on the order of 10 and 60 years for the northern and southern parts of the dunes, respectively.

Water-level measurements in the central part of the study area indicate that depth to water in wells increases with the increasing depth of the wells. This indicates vertical downward flow because of recharge. However, in wells near the coast and North Slough, flow is reversed. This is due to vertically upward discharge to the ocean or bay. Flow lines show that the deep flow of water is offshore. The hydrogeologic section ( $\left.A-A^{\prime}\right)$ illustrates the direction of flow and the distribution of head (fig. 6).

The ground-water flow directions are derived from a flow model developed during the course of this study. The flow of ground water was modeled using a three-dimensional digital flow model developed by Trescott (1975) and modified by Sapik (1988). 


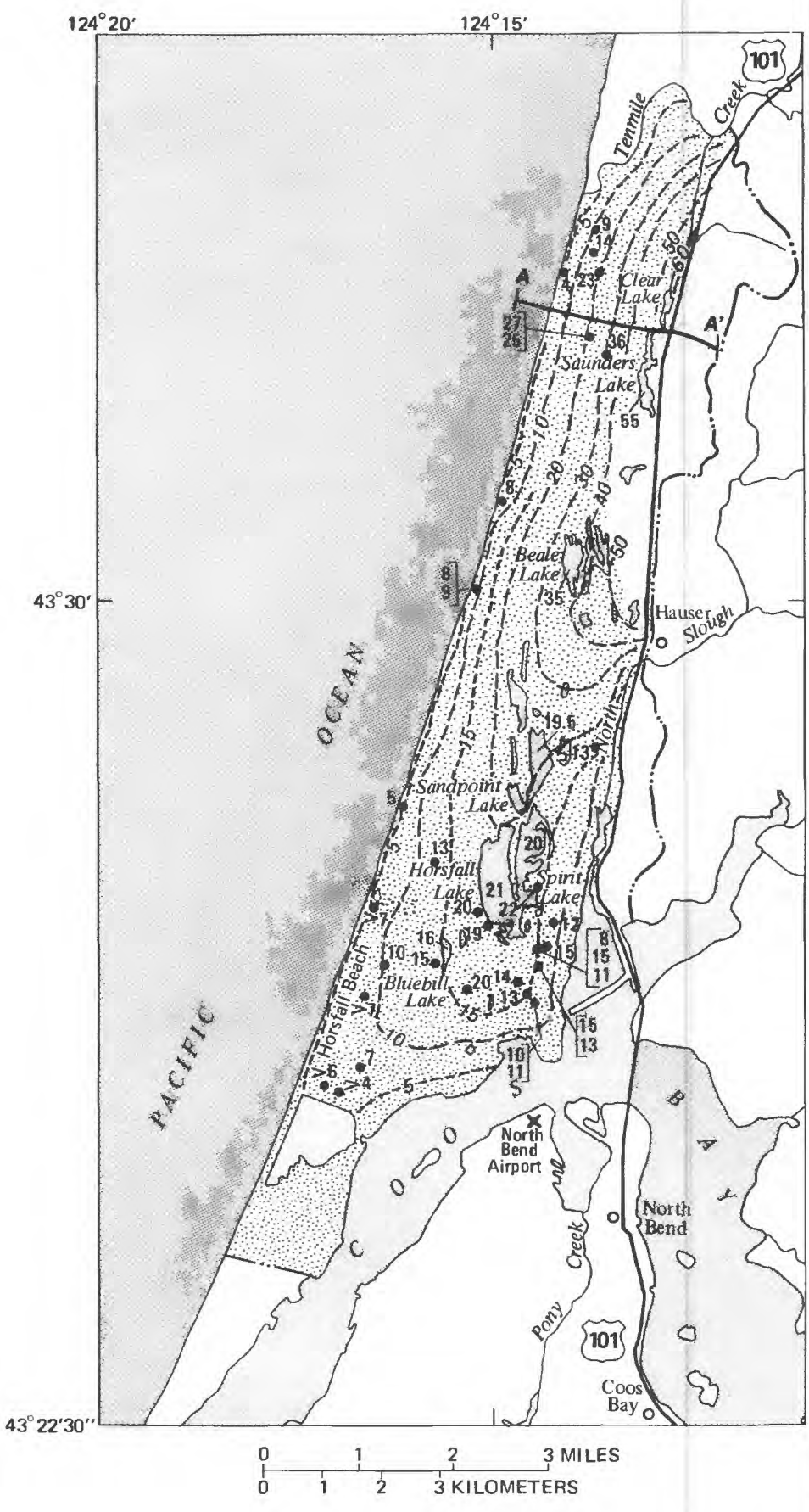

\section{EXPLANATION}

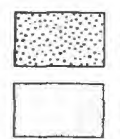

Dune-sand aquifer

Pleistocene and fine-grained Tertiary deposits

- - - Study area boundary

$A^{A} \quad A^{\prime}$ Trace of section-Shown in figure 6

- -30-- Simulated water-level contour-Shows altitude of water level. Contour interval 5 and 10 feet. Datum is sea level.

13

Well location-Number is altitude of observed water level, in feet above sea level. Grouped numbers indicate multiple data. $>$ indicates greater than value given.

21

Lake level-Number shown is altitude of water level, in feet above sea level.

Figure 5.--Water-level contours of the dune-sand aquifer. Contour lines derived from model-calculated heads in the upper layer of model. 

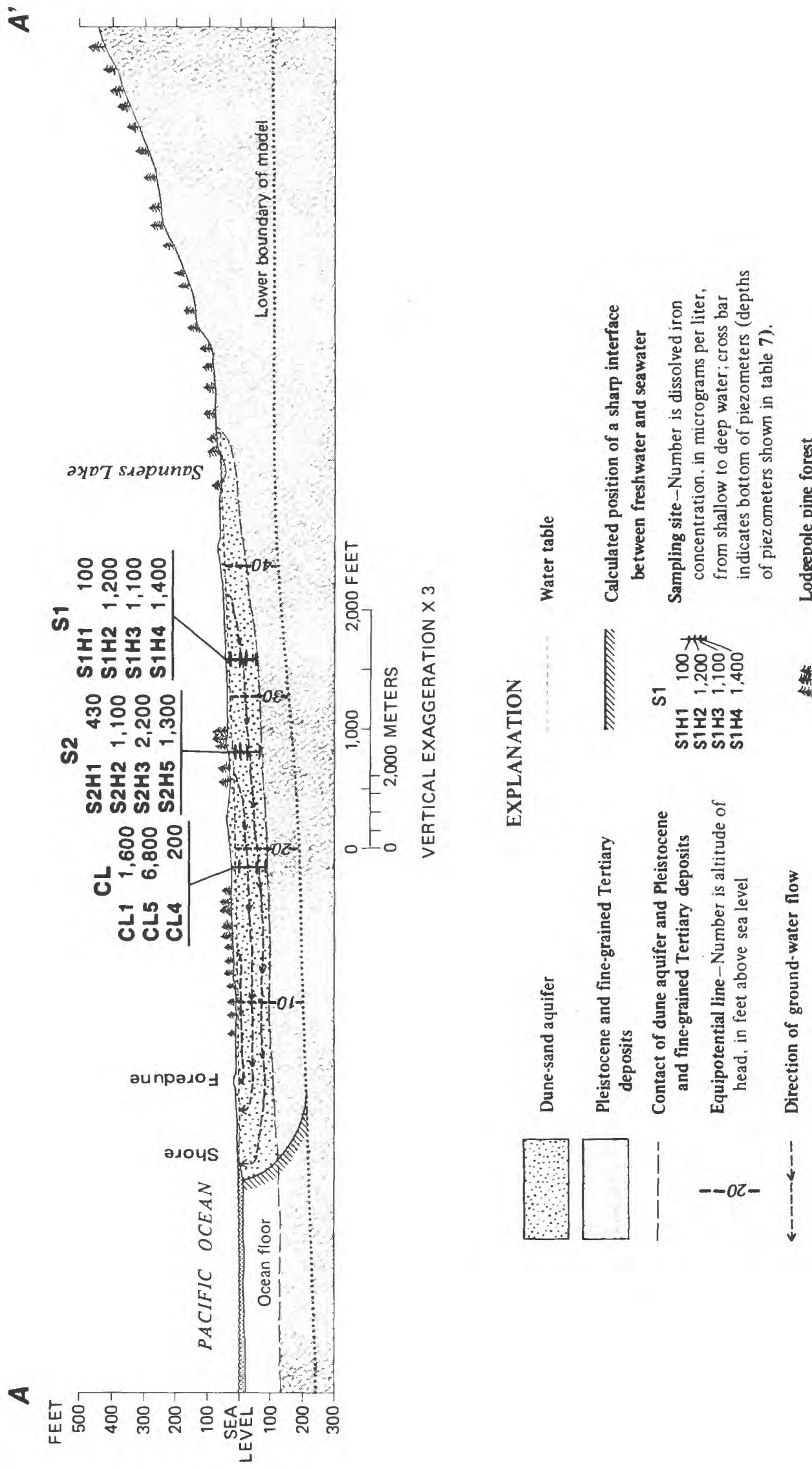

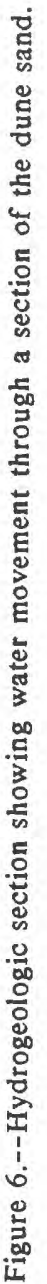

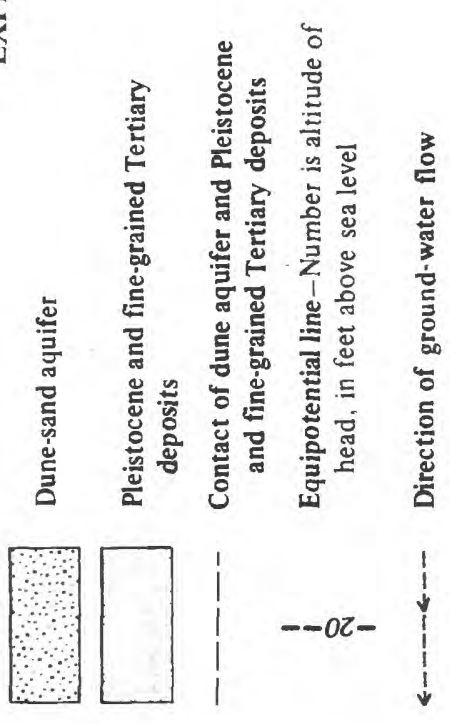


Iron, which can exist in solution in either the divalent ferrous $\left(\mathrm{Fe}^{+2}\right)$ or the trivalent ferric state $\left(\mathrm{Fe}^{\mathrm{T}}\right.$ ), is the fourth most abundant element in the earth's crust. The chemical behavior of ferrous and ferric iron and its solubility in water depends strongly on $\mathrm{pH}$ and the degree or intensity of oxidation or reduction, and the nature and concentration of dissolved organic compounds.

Under oxidizing conditions, ferric iron species are stable, and the solubility of iron is limited by the precipitation of ferric hydroxide and ferric oxyhydroxides. Ferric species are relatively insoluble between pH 5 and 9. Under reducing conditions, ground water can have higher concentrations of iron than under oxidizing conditions. If ground water becomes depleted in oxygen through the decay of organic matter or other oxygen-consuming processes, the reduced, or ferrous, forms of iron are predominant. The solubility of iron under reducing conditions where carbon dioxide is relatively abundant may be controlled by precipitation of siderite $\left(\mathrm{FeCO}_{3}\right)$, but ferrous iron concentrations of several tens of thousands of micrograms per liter can remain in solution if the $\mathrm{pH}$ is less than about 6.5. If the $\mathrm{pH}$ of such a solution were to increase to 8.0 , owing to reactions with other solids it encounters along its flow path, siderite precipitation could become a more effective control, and the iron concentrations could be decreased to less than a thousand micrograms per liter. In more strongly reducing conditions, bacterially mediated reduction of sulfate could produce sulfide ions. Ferrous sulfides that might form in such solutions may decrease dissolved iron to smaller concentrations.

Many soluble organic compounds form complexes with both ferrous and ferric iron (Theis and Singer, 1974; Tipping, 1981). These complexes are less affected by oxidation or other precipitation reactions than are the uncomplexed forms of iron, and thus increase dissolved iron concentrations. Besides stabilizing iron against oxidation and forming complex ions, natural organic compounds in water also have been found to reduce the oxidation state of many inorganic species; these natural organic compounds are the most readily available reductants in most natural systems (Stevenson, 1985). It also is possible for organic-rich waters to stabilize colloidal suspensions of ferric hydroxide. These and other aspects of the aqueous chemistry of iron have been discussed more extensively by Hem (1967; 1985, p. 77-84) and Nordstrom and Munoz (1986).

\section{Iron and Calcium Carbonate in Sands}

Sand samples were obtained from cores and drill cuttings of wells. The primary minerals present were quartz, K-feldspar, anorthoclase, and plagioclase of variable composition. Minor minerals that are iron bearing include iron-titanium oxides, pyroxene, tourmaline, and pyrite. Pyrite was found as inclusions in anorthoclase and $\mathrm{K}$-feldspar. In most samples, the mineralogy of individual grains was inferred from SEM/EDXRF analyses of polished grain surfaces and correlation analysis of the major oxide composition of the bulk sands (table 1). Correlation analysis (not shown) indicates a strong relation between iron ( $\mathrm{Fe})$, magnesium ( $\mathrm{Mg}$ ), and titanium (Ti) in the minerals. This suggests that iron is present in iron-titanium oxides (ilmenite and titano-magnetite) and iron and magnesium in pyroxene (mostly hypersthene). 
Table 1.--Major chemical oxide composition of sands by X-ray fluorescence spectroscopy

(Sample depths are in feet $(\mathrm{ft})$ above or below sea level; see plate 1 for location of piezometers; $\mathrm{SiO}_{2}=$ silica dioxide; $\mathrm{Al}_{2} \mathrm{O}_{3}=$ aluminum oxide; $\mathrm{Fe}_{2} \mathrm{O}_{3}=$ total iron as ferric oxide; $\mathrm{FeO}=$ ferrous oxide; $\mathrm{MgO}=2$ magnesium oxide; $\mathrm{CaO}^{3}=$ calcium oxide; $\mathrm{Na}_{2} \mathrm{O}^{2}={ }^{3}$ sodium oxide; $\mathrm{K}_{2} \mathrm{O}=$ potassium oxide; $\mathrm{TiO}_{2}=$ titanium oxide, $\mathrm{P}_{2} \mathrm{O}_{5}=$ phosphorous oxide; $\mathrm{MnO}=$ manganous oxide; LOI = loss $\mathrm{On}$ ignition at $920{ }^{\circ} \mathrm{C}$ for ${ }^{2} 1$ hour; $<=1$ less than.]

Sample description and sample depths

1. Composite of sand, 41 to $24 \mathrm{ft}$

2. Composite of sand, 41 to $0 \mathrm{ft}$

3. Sample of sand at $-17.5 \mathrm{ft}$

4. Sample of sand at $10 \mathrm{ft}$

5. Composite of sand, 29 to $-18.5 \mathrm{ft}$

6. Sample of sand at $-18.5 \mathrm{ft}$

7. Composite of sand at $-30.5 \mathrm{ft}$
8. Sample of sand at $11.5 \mathrm{ft}$

9. Composite of sand, 24 to $-8 \mathrm{ft}$

10. Sample of sand at $-3 \mathrm{ft}$

11. Composite of sand, 16 to $-18 \mathrm{ft}$

12. Composite of sand, 16 to $-47 \mathrm{ft}$

13. Sample of sand at $-47 \mathrm{ft}$

14. Sample of sand at $-10 \mathrm{ft}$
15. Sample of sand at $-25 \mathrm{ft}$

16. Sample of sand at $-50 \mathrm{ft}$

17. Sample of sand at $-85 \mathrm{ft}$

18. Sample of sand at $-40 \mathrm{ft}$

19. Sample of sand at $-115 \mathrm{ft}$

20. Sample of sand at $-16 \mathrm{ft}$

21. Sample of sand at $-151 \mathrm{ft}$

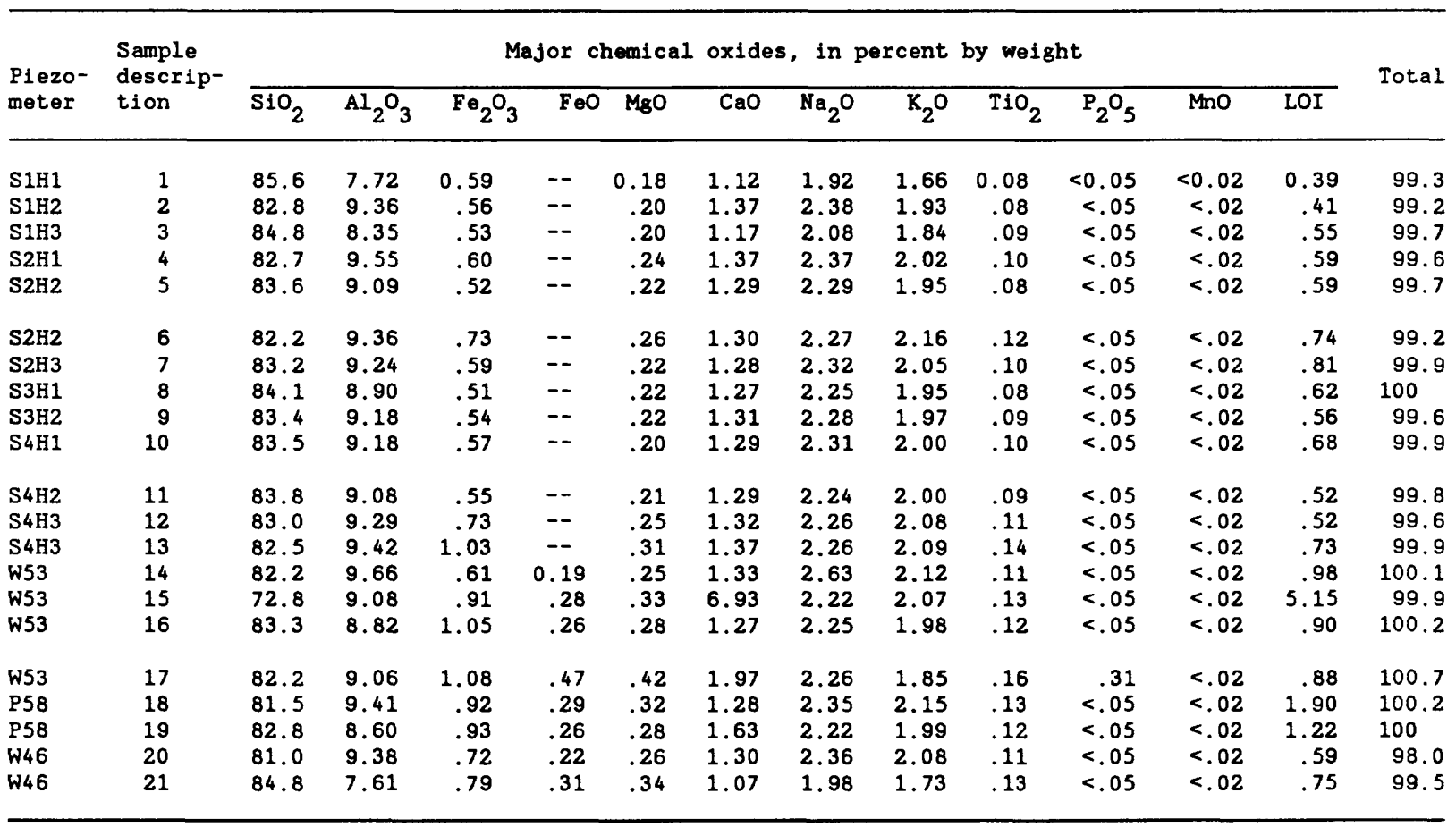

Discrete iron oxide coatings were not apparent in any of the sand samples examined. However, some grain surfaces showed accumulations of submicrometer to micrometer-sized alumino-silicate particles which appeared to be enriched in iron. This material could represent either a build-up of clay particles and amorphous iron oxides from the alteration of grain surfaces, or finegrained material deposited with the sands.

Iron in bulk sands, expressed as $\mathrm{Fe}_{2} \mathrm{O}_{3}$, ranged from 0.51 to 1.08 percent by weight (table 1 ). The reduced form of iron as FeO varied from 27 to 48 percent of the total iron. In general, there is considerable uniformity in iron content of sands between sites and at depths (table 1). 
The amorphous iron concentration was estimated by extracting the samples for 6 hours in 0.2 molar ammonium oxalate and then acidifying them to $\mathrm{pH} 3$ with oxalic acid (McKeague and Day, 1967). Iron extracted by this technique ranged from 0.024 to 0.17 percent by weight ( 240 to 1,700 micrograms per gram), representing 6 to 18 percent of the total iron in the sand (table 2). Even at these low concentrations, however, amorphous iron could be a significant source of dissolved iron to the ground water.

Micrometer-size particles coating the grain surfaces were particularly noticeable by SEM analyses on some samples of deeper sands. To evaluate the concentration and composition of fine particles, samples were sonicated at high power in distilled water for 1 hour and then sieved at 40 micrometers. After collection on a 0.45 -micron filter, the resulting fines were analyzed for major oxide composition using EDXRF. Iron, as $\mathrm{Fe}_{2} \mathrm{O}_{3}$, in the fine fraction separated by sonication ranged from 0.35 to 1.42 percent by weight, about 10 times more concentrated than the iron content of the bulk sand (Bortleson and others, 1989).

Even though the iron in the less than 40 micrometer fraction represents only a small part of the total iron present, it could account for a significant amount of the amorphous or oxalate extractable iron. This suggests that the fine particles could be a significant source of iron to the ground water.

Shell fragments mixed with sand are common in the deeper part of the sand aquifer. The calcium carbonate content of shell-containing sands ranged from 0.40 to 20 percent by weight. The mean calcium carbonate content was about 1.5 weight percent, which was about 4 times more than sands with no visual evidence of shell material being present (table 3 ).

\section{Dissolved Iron Concentrations in the Shallow Part of the Aquifer}

Shallow ground water was sampled usually from 4 to 6 feet below the water table in areas of bare sand and lodgepole pine forest to determine the effects of vegetation on iron mobilization. Concentrations of dissolved iron in shallow ground water were found to be 5 to 120 times greater in areas that had infiltrated dense forest compared to bare sand along the inland margin of the forest (Bortleson and others, 1989).

The overall effect of vegetation growing on the sand dune is to accelerate the dissolution of iron-bearing minerals in the sand. The sand aquifer contains minerals such as pyroxenes and iron-titanium oxides that are relatively high in iron content. Iron is released when these minerals are attacked by a $\mathrm{CO}_{2}$-charged ground water with $\mathrm{pH} 5.6$ to 6.7 . Recharge water is also rich in dissolved organic compounds, which can accelerate the chemical weathering of primary silicate minerals as discussed by Bennett and others (1988) and Huang and Keller (1970). Silicate hydrolysis reactions can be schematically shown as follows:

$\mathrm{Fe}$ silicate $(\mathrm{s})+\mathrm{H}_{2} \mathrm{O}+\mathrm{CO}_{2} \rightarrow$ clay + cations $+\mathrm{Fe}^{+3} / \mathrm{Fe}^{+2}+\mathrm{HCO}_{3}^{-}+\mathrm{H}_{2} \mathrm{SiO}_{4}{ }^{0}$.

Mechanisms for pyroxene dissolution are discussed by Berner and Schott (1982) and Schott and Berner (1983). Iron-titanium oxide minerals also are present in the sands. Ilmenite, $\mathrm{FeTiO}_{3}$, for example is relatively stable and is probably less important than the pyroxenes and other iron-bearing silicate minerals as a source of iron to ground water. 
Table 2.--Total iron concentration in bulk sand sample and percent of total iron in acid ammonium oxalate extract

[Sample depths are in feet (ft) above or below sea level; see plate 1 for location of piezometers.]

Sample description and sample depths

1. Composite of sand, 41 to $24 \mathrm{ft}$ 14. Sample of sand at $-10 \mathrm{ft}$

3. Sample of sand at $-17.5 \mathrm{ft}$ 15. Sample of sand at $-25 \mathrm{ft}$

4. Sample of sand at $10 \mathrm{ft}$ 16. Sample of sand at $-50 \mathrm{ft}$

6. Sample of sand at $-18.5 \mathrm{ft} \quad 17$. Sample of sand at $-85 \mathrm{ft}$

8. Sample of sand at $11.5 \mathrm{ft}$ 18. Sample of sand at $-40 \mathrm{ft}$

9. Composite of sand, 24 to $-8 \mathrm{ft} 19$. Sample of sand at $-115 \mathrm{ft}$

10. Sample of sand at $-3 \mathrm{ft} 20$. Sample of sand at $-16 \mathrm{ft}$

13. Sample of sand at $-47 \mathrm{ft} 21$. Sample of sand at $-151 \mathrm{ft}$

\begin{tabular}{|c|c|c|c|c|}
\hline \multirow[b]{2}{*}{ Sample } & \multirow[b]{2}{*}{$\begin{array}{l}\text { Piezo- } \\
\text { meter }\end{array}$} & \multicolumn{3}{|c|}{ Bulk sample } \\
\hline & & $\begin{array}{l}\text { Total iron } \\
\text { (- - microgram }\end{array}$ & $\begin{array}{r}\text { Amorph } \\
\text { acid a } \\
\text { oxalat } \\
\text { per gram }\end{array}$ & $\begin{array}{l}\text { iron, } \\
\text { nium } \\
\text { xtraction } \\
\text { n-.....- }\end{array}$ \\
\hline 1 & S1H1 & 4,100 & 530 & ${ }^{a}(13)$ \\
\hline 3 & S1H3 & 3,700 & 340 & $(9)$ \\
\hline 4 & $\mathrm{~S} 2 \mathrm{H} 1$ & 4,200 & 300 & (7) \\
\hline 6 & $\mathrm{~S} 2 \mathrm{H} 2$ & 5,100 & 630 & (12) \\
\hline 8 & S3H1 & 3,600 & 530 & (15) \\
\hline 9 & $\mathrm{~S} 3 \mathrm{H} 2$ & 3,800 & 240 & $(6)$ \\
\hline 10 & S4H1 & 4,000 & 570 & (14) \\
\hline 13 & $\mathrm{~S} 4 \mathrm{H} 3$ & 7,200 & 910 & (13) \\
\hline 14 & W53 & 4,300 & 320 & (6) \\
\hline 15 & W53 & 6,300 & 1,400 & $(16)$ \\
\hline 16 & W53 & 7,300 & 1,700 & (18) \\
\hline 17 & W53 & 7,500 & 740 & (7) \\
\hline 18 & P58 & 6,400 & 1,400 & $(16)$ \\
\hline 19 & P58 & 6,500 & 1,500 & (17) \\
\hline 20 & W46 & 5,000 & 710 & (11) \\
\hline 21 & W46 & 5,500 & 690 & (9) \\
\hline
\end{tabular}

a Number inside parenthesis is percent of iron in acid ammonium oxalate extract to total iron concentration of bulk sample. 
Table 3.- - Calcium carbonate content of sands

[Calcium carbonate determined by loss of inorganic carbon as carbon dioxide at $950{ }^{\circ} \mathrm{C}$ after loss of organic carbon as carbon dioxide at $\left.550^{\circ} \mathrm{C}.\right]$

\begin{tabular}{|c|c|c|c|c|}
\hline \multirow{2}{*}{$\begin{array}{l}\text { Sand } \\
\text { type }\end{array}$} & \multirow{2}{*}{$\begin{array}{l}\text { Number of } \\
\text { samples }\end{array}$} & \multicolumn{3}{|c|}{$\begin{array}{l}\text { Calcium carbonate, } \\
\text { in weighted percent }\end{array}$} \\
\hline & & Minimum & Maximum & Mean \\
\hline & & 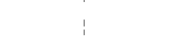 & & \\
\hline Sand & 46 & 0.16 & 0.84 & 0.41 \\
\hline $\begin{array}{l}\text { Shell fragments } \\
\text { mixed with sand }\end{array}$ & 57 & .40 & 20 & 1.5 \\
\hline
\end{tabular}

Pyrite is another primary mineral present in minor amounts in sands. It is unstable in oxygenated water and will react according to the reaction,

$$
\mathrm{FeS}_{2}+(7 / 2) \mathrm{O}_{2}+\mathrm{H}_{2} \mathrm{O} \rightarrow \mathrm{Fe}^{+^{2}}+2 \mathrm{H}^{+}+2 \mathrm{SO}_{4}^{-2} \text {. }
$$

Dissolved ferrous ions produced by this reaction also are unstable in oxygenated water and will react to precipitate ferric hydroxide:

$$
\mathrm{Fe}^{+^{2}}+(5 / 2) \mathrm{H}_{2} \mathrm{O}+1 / 4 \mathrm{O}_{2} \rightarrow \mathrm{Fe}(\mathrm{OH})_{3}+2 \mathrm{H}^{+} \text {. }
$$

Reactions 2 and 3 can occur in the unsaturated sands where infiltrating water contains dissolved oxygen obtained from the atmosphere. In the absence of free oxygen, organic compounds coupled with bacterial action can reduce ferric to ferrous iron (Lovley and others, 1987).

Concentrations of dissolved organic carbon (DOC) are about 10 times greater in shallow ground water beneath dense coastal forest than they are in bare sand (table 4). DOC concentrations ranged from 7.8 to $10 \mathrm{mg} / \mathrm{L}$

(milligrams per liter) in ground water beneath dense forest of coastal deflation plain. Dissolved organic compounds can increase the capacity of water to dissolve iron minerals by acid hydrolysis. This process is similar to normal silicate hydrolysis (reaction 1). The oxidation of organic matter constitutes a continuous source of hydrogen ions and drives the chemical weathering reaction irreversibly. Sources of hydrogen ions in forest-covered areas include carbon dioxide from plant respiration and decay, and organic acids leached to shallow ground water from the forest litter and root zones. Carbonic acid dissociates to bicarbonate and carbonate ions, supplying hydrogen ions for chemical weathering according to the reaction:

$$
\mathrm{CO}_{2} \text { (gas) }+\mathrm{H}_{2} \mathrm{O} \rightleftarrows \mathrm{H}_{2} \mathrm{CO}_{3} \rightleftarrows \mathrm{H}^{+}+\mathrm{HCO}_{3}^{-} \text {. }
$$


Table 4.--Chemistry of shallow ground water beneath various land covers

[See plate 1 for location of piezometers; values in milligrams per liter except where indicated; -- = no data; n.d. = dissolved ferrous iron not detected in solution; ${ }^{\circ} \mathrm{C}=$ degrees Celsius; $<=1$ less than.]

\begin{tabular}{|c|c|c|c|c|c|c|c|c|c|c|c|}
\hline \multirow[b]{2}{*}{$\begin{array}{l}\text { Piezo- } \\
\text { meter }\end{array}$} & \multirow[b]{2}{*}{ Date } & \multirow{2}{*}{$\begin{array}{l}\text { Depth to } \\
\text { bottom of } \\
\text { well open- } \\
\text { ing (feet } \\
\text { below land } \\
\text { surface) }\end{array}$} & \multirow{2}{*}{$\begin{array}{l}\text { Depth to } \\
\text { water } \\
\text { (feet be- } \\
\text { low land } \\
\text { surface) }\end{array}$} & \multirow{2}{*}{$\begin{array}{l}\text { Specific } \\
\text { conduct- } \\
\text { ance } \\
\text { (micro- } \\
\text { siemens } \\
\text { at } 25^{\circ} \mathrm{C} \text { ) }\end{array}$} & \multirow[b]{2}{*}{$\begin{array}{c}\text { pH, } \\
\text { in } \\
\text { units } \\
\end{array}$} & \multirow[b]{2}{*}{$\begin{array}{r}\text { Temper- } \\
\text { ature } \\
\left({ }^{\circ} \mathrm{C}\right) \\
\end{array}$} & \multirow[b]{2}{*}{$\begin{array}{l}\text { Dis- } \\
\text { solved } \\
\text { oxygen }\end{array}$} & \multirow[b]{2}{*}{$\begin{array}{l}\text { Bicar- } \\
\text { bonate }\end{array}$} & \multirow{2}{*}{$\begin{array}{l}\text { Dis- } \\
\text { solved } \\
\text { organic } \\
\text { carbon, } \\
\text { as C }\end{array}$} & \multicolumn{2}{|c|}{ Dissolved iron } \\
\hline & & & & & & & & & & $\begin{array}{c}\text { Ferric }+ \\
\text { ferrous } \\
\text { (micrograms }\end{array}$ & $\begin{array}{l}\text { Ferrous } \\
\text { per } 1 \pm \text { ter) }\end{array}$ \\
\hline \multicolumn{12}{|c|}{ Bare sand } \\
\hline TM1 & $6 / 2 / 86$ & 6.1 & 0.33 & 47 & 6.2 & 14.3 & 4.7 & 14 & 0.9 & 15 & n.d. \\
\hline S3H1 & $6 / 2 / 86$ & 13.5 & .7 & 85 & 5.6 & 13.2 & .0 & 14 & 1.4 & 30 & n.d. \\
\hline BL1A & $3 / 10 / 87$ & 6.7 & .5 & 73 & 5.9 & 11.4 & .0 & 16 & - & 910 & 540 \\
\hline BA1 & $4 / 30 / 88$ & 9.6 & 1.4 & 35 & 5.9 & 13.5 & -- & 7.0 & .7 & 160 & 80 \\
\hline BA2 & $5 / 3 / 88$ & 9.8 & 2.7 & 39 & 5.7 & 13.5 & 4.7 & 7.0 & -- & $<10$ & n.d. \\
\hline $\mathrm{BA2}$ & $7 / 23 / 88$ & 9.8 & 3.8 & 50 & 6.1 & 14.7 & 2.9 & 11 & -- & $<10$ & n.d. \\
\hline BA3 & $7 / 22 / 88$ & 9.8 & 3.6 & 85 & 6.2 & 14.6 & .5 & 28 & -- & 970 & 660 \\
\hline \multicolumn{12}{|c|}{ European beach grass } \\
\hline BE2 & $5 / 8 / 88$ & 9.7 & 3.1 & 42 & 5.8 & 13.5 & 2.2 & 11 & -- & 30 & 30 \\
\hline BE2 & $7 / 23 / 88$ & 9.7 & 4.4 & 46 & 6.0 & 13.8 & .7 & 10 & -- & 300 & 310 \\
\hline \multicolumn{12}{|c|}{ Sedge and some willow (mostly herbacious) } \\
\hline SS1 & $6 / 17 / 87$ & 6.0 & 1.2 & 175 & 6.4 & 15.0 & .3 & 72 & 5.6 & 1,500 & 800 \\
\hline SS1A & $6 / 17 / 87$ & 5.0 & .3 & 190 & 6.4 & 14.5 & .0 & 94 & 4.9 & 2,900 & 1,600 \\
\hline SS3 & $3 / 6 / 87$ & 22 & -- & 198 & 6.2 & 17.0 & .0 & 96 & .9 & 430 & 15 \\
\hline & & & Sedge, blue & berry, and & some & willow（n & ostly lo & w woody & shrub) & & \\
\hline SS4 & $6 / 17 / 87$ & 5.7 & 1.5 & 295 & 6.4 & 14.5 & .0 & 99 & 13 & 2,600 & 2,200 \\
\hline ss5 & $6 / 17 / 87$ & 5.5 & 1.7 & 213 & 6.5 & 14.5 & .0 & 82 & 5.3 & 2,700 & 2,700 \\
\hline \multicolumn{12}{|c|}{ Forest of old deflation plain } \\
\hline TM2 & $6 / 2 / 86$ & 8.0 & 4.4 & 275 & 5.6 & 12.5 & 1.2 & 14 & 17 & 400 & n.d. \\
\hline S2H1 & $6 / 5 / 86$ & 19 & 1.1 & 70 & 6.1 & 13.0 & .0 & 16 & $1.3(3)$ & $2 / 86)^{a} 430$ & 140 \\
\hline BB1 & $5 / 28 / 86$ & 22 & 4.8 & 115 & 6.7 & 12.5 & .0 & 50 & 11 & 14,000 & 13,000 \\
\hline BB3 & $6 / 1 / 86$ & 7.6 & 3.3 & 44 & 5.8 & 13.0 & 1.7 & 12 & 9.8 & 1,100 & 820 \\
\hline BB7 & $6 / 1 / 86$ & 20 & 4.4 & 93 & 6.2 & 13.0 & .0 & 28 & 1.6 & 4,200 & 2,900 \\
\hline \multicolumn{12}{|c|}{ Forest of coastal deflation plain } \\
\hline CL2 & $6 / 2 / 86$ & 7.5 & 2.3 & 146 & 6.2 & 13.0 & .0 & 32 & 7.8 & 7,300 & 7,000 \\
\hline SL2 & $6 / 4 / 86$ & 6.6 & 1.3 & 198 & 6.4 & 13.5 & .0 & 64 & 9.2 & 12,000 & 9,300 \\
\hline BL2 & $6 / 4 / 86$ & 6.5 & .9 & 285 & 6.6 & 13.0 & .0 & 94 & 10 & 27,000 & 26,000 \\
\hline SN2 & $6 / 4 / 86$ & 5.9 & 1.5 & 260 & 6.3 & 15.0 & .0 & 76 & 8.8 & 18,000 & 14,000 \\
\hline HF2H1 & $6 / 6 / 86$ & 15 & 2.4 & 320 & 6.1 & 12.0 & .0 & 34 & - & 10,000 & 8,800 \\
\hline
\end{tabular}

a Dissolved organic carbon collected on date shown in parenthesis.

Large concentrations of bicarbonate in water (table 4) that infiltrate dense forest areas indicate that the reaction of $\mathrm{CO}_{2}$ and $\mathrm{H}_{2} \mathrm{O}$ is an important source of hydrogen ions. The rate of which $\mathrm{CO}_{2}$ derived from plant respiration is delivered to infiltrating water can be several orders of magnitude greater than that resulting from rainwater simply passing through the atmosphere, thereby increasing aqueous $\mathrm{CO}_{2}$ in the shallow ground water and accelerating the rate of weathering. $\log \mathrm{pCO}_{2}$ values are consistently higher in water that had infiltrated forest areas as compared to bare sand (Bortleson and others, 1989). The $\mathrm{pH}$ was slightly higher in water that had infiltrated areas of coastal forest than bare sands, and total solute concentrations were larger by a factor of two or more, indicating that the progress of mineral weathering and reduction of amorphous ferric oxyhydroxide compounds is notably more rapid in forested areas than in bare sand areas. 
Dissolved oxygen concentrations in water that infiltrated bare sand or forest areas are usually $0.0 \mathrm{mg} / \mathrm{L}$ (table 4). The lack of dissolved oxygen results from the oxidation of organic matter (symbolized as $\mathrm{CH}_{2} \mathrm{O}$ ) by bacteria, which consumes dissolved oxygen according to the reaction,

$$
\mathrm{O}_{2} \text { (gas) }+\mathrm{CH}_{2} \mathrm{O} \rightarrow \mathrm{CO}_{2}+\mathrm{H}_{2} \mathrm{O} \text {. }
$$

The rapid consumption of dissolved oxygen in water infiltrating bare sand also is due in part to the oxidation of pyrite and ferrous iron released during silicate and pyrite weathering. As previously mentioned, ferrous iron makes up 27 to 48 percent of the total iron content of the sands.

When molecular oxygen has been depleted, the decay of organic matter can continue by a series of reactions which represent successively lower oxidation-intensity levels. As potential oxidizing agents in the ground-water system such as $\mathrm{O}_{2}, \mathrm{NO}_{3}^{-}, \mathrm{MnO}_{2}, \mathrm{Fe}(\mathrm{OH})_{3}$, and $\mathrm{SO}_{4}^{-2}$ are depleted, the system becomes increasingly reduced. Some of the bacterially mediated reactions that consume organic matter and reduce inorganic constituents include denitrification, ferric iron reduction, and sulfate reduction. Sulfate reduction may be written as,

$$
2 \mathrm{CH}_{2} \mathrm{O}+\mathrm{SO}_{4}^{-2} \rightarrow \mathrm{HS}^{-}+2 \mathrm{HCO}_{3}^{-}+\mathrm{H}^{+} .
$$

Many of the waters that infiltrate areas of dense forest have a detectable odor of hydrogen sulfide $\left(\mathrm{H}_{2} \mathrm{~S}\right)$, indicating that sulfate reduction is occurring. The presence of significant quantities of sulfate ion in the same water indicates, however, that sulfate reduction is partial. If any dissolved iron is present, sulfide species will react with ferrous iron to form a precipitate of iron sulfides. There is no evidence to indicate that sulfide precipitation has an important influence on iron behavior in the shallow ground water, but could be important in limiting iron concentrations in deeper ground water.

The concentration of dissolved iron is increased by complexation with dissolved organic compounds. As a general rule, large concentrations of DOC are accompanied by an increased capacity for complexation (Thurman, 1985, $\mathrm{p}$. 411). Iron readily complexes with organic-degradation products derived from microbes and with water-soluble organic constituents, primarily humic and fulvic acids; complexing agents of iron are known to increase the mobility of iron (Walte and More1, 1984; Zinder and others, 1986; and Neal and others, 1986). A positive correlation of 99-percent significance $(r=0.84, n=15)$ was calculated between DOC and dissolved iron, strongly suggesting complexation of iron by organic compounds (Bortleson and others, 1989). Furthermore, dissolved ferric iron is commonly present together with ferrous iron (table 4). Dissolved ferric iron, which is normally unstable in deoxygenated waters, is apparently stabilized by organic complexation.

Iron released by dissolution of iron-bearing minerals is partly utilized by lodgepole pine and other vegetation; iron not needed by plants is periodically added to the ground water by recharge events. The extent to which dissolved iron moves to the water table as a result of plant mineralization is unknown. However, the direct contribution of pine-needlebound iron appears to be small. Tests of fresh moderately decomposed and greatly decomposed pine needles indicate that plant-tissue-bound iron is not readily released upon decomposition of the pine needles; much of the iron 
remains in the surficial litter regardless of the degree of needle decomposition (Bortleson and others, 1989). The degree to which iron is mineralized and directly leached to the shallow ground water needs further study.

Zinder (1962) examined soil patterns under individual lodgepole pine trees growing on a sand dune area in California. He found the soil properties varied with distance from the tree trunk. The $\mathrm{pH}$ of soil was lowest (5.7) adjacent to the tree trunk and rose progressively with distance from the tree to 7.2 on the open sand dune. Some studies suggest that soil surrounding lodgepole pine rootlets provides an environment favorable for microbic organic compounds to form stable chelates with iron (Reid and others, 1984). For example, malic acid is an important constituent of the root exudates of several plant species. It has been shown to increase the solubility of soil iron (Jaurequi and Reisenauer, 1982). It remains undetermined whether or not iron-complexing compounds exuded by lodgepole pine rootlets are an important source of dissolved organic compounds in shallow ground water.

To determine the effects of vegetation on iron concentrations in the shallow part of the dune-sand aquifer, water was sampled beneath various land covers that are listed below.

\title{
Land cover
}

\author{
Bare sand \\ Forest of old deflation plain \\ Dense forest of coastal deflation plain \\ European beach grass \\ Sedge and some willow (mostly herbacious) \\ Sedge, blueberry, and some willow (low woody shrub)
}

Initially the study on effects of vegetation on iron concentrations involved sampling shallow ground water that had infiltrated bare sand and forest areas. Lodgepole pine forest is the predominant vegetation on the dunes. However, other forms of vegetation also grow extensively on the dunes. Ground water that had infiltrated areas of herbacious vegetation of European beach grass and sedge generally contained smaller concentrations of dissolved iron than water that had infiltrated woody shrub areas (table 4). These data show a correlation between the amount of dissolved iron in shallow ground water and the biomass of the plant community. Trees, with the large amount of biomass associated with their structure, require a disproportionate amount of carbohydrates for respiration compared to other plants (Waring and Schlesinger, 1985, p. 20). Carbon dioxide generated by plant respiration above ground is lost to the atmosphere through the respiring tissue of foliage, branches, and stems, but below ground $\mathrm{CO}_{2}$ is effused by root respiration to the soil. The amount of $\mathrm{CO}_{2}$ respired by roots below ground and $\mathrm{CO}_{2}$ generated by decomposition of organic matter in the soil provides a source of acidity for chemical weathering of iron-bearing minerals. Larger concentrations of iron found in shallow ground water beneath the coastal deflation plain compared to the old deflation plain is probably related to the higher density of vegetation and longer periods and greater areas of inundation during the wet season near the coast compared to inland areas. 
A statistical summary of dissolved iron concentration in the shallow ground water beneath each land cover listed previously is shown in table 5 . Iron concentrations in shallow water range from largest to smallest as follows: forest of coastal deflation plain $>$ forest of old deflation plain > woody shrub $($ low $)=$ sedge $>$ European beach grass $=$ bare $s$ and .

The dissolved iron concentrations in the shallow part of the aquifer beneath forest and bare sand can be estimated using the land cover map shown on plate 1 and the dissolved iron concentration of water beneath major land cover shown in table 5. The percent cover on the sand dune is greatest for old deflation plain forest and bare sand. However, areas of low woody shrub and sedge make up a large part of the southern 2 miles of the coastal deflation plain. These land covers are not mapped separately and not specified on plate 1 . Beach grass is the predominant vegetation on the foredune, but can be found throughout inland areas of the dunes, commonly in scattered areas.

Table 5.--Dissolved iron concentrations in shallow ground water beneath various land covers

\begin{tabular}{|c|c|c|c|c|c|}
\hline \multirow[b]{2}{*}{ Land cover } & \multirow[b]{2}{*}{$\begin{array}{l}\text { Number } \\
\text { of } \\
\text { sites }\end{array}$} & \multicolumn{4}{|c|}{$\begin{array}{c}\text { Dissolved iron (ferric }+ \\
\text { ferrous) concentration }\end{array}$} \\
\hline & & Mean & $\begin{array}{l}\text { Median } \\
\text {-micrograms }\end{array}$ & $\begin{array}{l}\text { Minimum } \\
\text { per liter }\end{array}$ & $\begin{array}{l}\text { Maximum } \\
\text { r....-) }\end{array}$ \\
\hline Bare sand & $7(8)$ & 280 & 90 & $<10$ & 970 \\
\hline European beach grass & $2(3)$ & 210 & 30 & 30 & 300 \\
\hline Sedge and some willow & $3(3)$ & 1,600 & 1,500 & 430 & 2,900 \\
\hline Woody shrub (low) & $2(2)$ & 2,700 & -- & 2,600 & 2,700 \\
\hline $\begin{array}{l}\text { Forest of old } \\
\text { deflation plain }\end{array}$ & $7(7)$ & 4,800 & 3,800 & 400 & 14,000 \\
\hline $\begin{array}{l}\text { Forest of coastal } \\
\text { deflation plain }\end{array}$ & $5(5)$ & 15,000 & 12,000 & 7,300 & 27,000 \\
\hline
\end{tabular}

Number in parenthesis is equal to number of samples.

\section{Dissolved Iron Concentrations in the Deep Part of the Aquifer}

Dissolved iron concentrations are small in the deep part of the aquifer in the southern part of the dunes. The exception was the moderately large dissolved iron concentration of $4,600 \mu \mathrm{g} / \mathrm{L}$ observed in piezometer SCP5C ( $t a b l e$ 6). The piezometer was at -70 feet elevation and was the shallowest water sampled in the southern part of the dunes. For the remaining 14 piezometers 
listed in table 6 for the southern part of the dunes, dissolved iron concentrations range from 7 to $690 \mu \mathrm{g} / \mathrm{L}$, elevations range from -85 to -157 feet, and $\mathrm{pH}$ values range from 7.4 to 8.5 .

Dissolved iron concentration and $\mathrm{pH}$ vertical profiles (fig. 7) for piezometer B3 located in the southern part of the dunes generally fluctuates in patterns reversed from each other. In the upper part of the aquifer, iron concentrations ranged from 2,000 to $37,000 \mu \mathrm{g} / \mathrm{L}$ (fig. 7). At about -80 feet elevation, dissolved iron concentration decreased sharply, and $\mathrm{pH}$ increased sharply (fig. 7). Larger iron concentrations are observed near the base of the sand aquifer ( -171 feet) where seawater encroachment in the aquifer causes mixing of freshwater and seawater. In general, other profiles of $\mathrm{pH}$ and dissolved iron concentrations measured at close intervals near Horsfall Beach in the southern part of the dunes (see pl. 1) showed similar trends of water

- with large iron concentrations overlying water with small concentrations (Dobberpuhl and others, 1985).

Table 6.--Chemistry of deep ground water

[See plate 1 for location of piezometers; values in milligrams per liter except where indicated; -- = indicate no data; $n . d$. = dissolved ferrous iron not detected in solution; ${ }^{\circ} \mathrm{C}=$ degrees Celsius; < = less than.]

\begin{tabular}{|c|c|c|c|c|c|c|c|c|c|c|c|}
\hline \multirow[b]{2}{*}{$\begin{array}{l}\text { Piezo- } \\
\text { meter }\end{array}$} & \multirow[b]{2}{*}{ Date } & \multirow{2}{*}{$\begin{array}{l}\text { Depth to } \\
\text { bottom of } \\
\text { well open- } \\
\text { ing (feet } \\
\text { below sea } \\
\text { level) }\end{array}$} & \multirow{2}{*}{$\begin{array}{l}\text { Depth to } \\
\text { water } \\
\text { (feet be- } \\
\text { low land } \\
\text { surface) }\end{array}$} & \multirow{2}{*}{$\begin{array}{l}\text { Specific } \\
\text { conduct- } \\
\text { ance } \\
\text { (micro- } \\
\text { siemens } \\
25^{\circ} \mathrm{C} \text { ) }\end{array}$} & \multirow[b]{2}{*}{$\begin{array}{l}\text { pH, } \\
\text { in } \\
\text { units }\end{array}$} & \multirow[b]{2}{*}{$\begin{array}{l}\text { Dis- } \\
\text { solved } \\
\text { oxygen }\end{array}$} & \multirow[b]{2}{*}{$\begin{array}{l}\text { Temper- } \\
\text { ature } \\
\left({ }^{\circ} \mathrm{C}\right)\end{array}$} & \multirow[b]{2}{*}{$\begin{array}{l}\text { Bicar- } \\
\text { bonate }\end{array}$} & \multirow{2}{*}{$\begin{array}{l}\text { Dis- } \\
\text { solved } \\
\text { organic } \\
\text { carbon, } \\
\text { as C }\end{array}$} & \multicolumn{2}{|c|}{ Dissolved iron } \\
\hline & & & & & & & & & & $\begin{array}{l}\text { Ferric }+ \\
\text { ferrous } \\
\text { (micrograms }\end{array}$ & $\begin{array}{r}\text { Ferrous } \\
\text { per liter) }\end{array}$ \\
\hline \multicolumn{12}{|c|}{ Northern part of dunes } \\
\hline TM4 & $3 / 6 / 87$ & 105 & -- & 152 & 7.5 & 0.1 & 14.5 & 58 & -- & 260 & $<10$ \\
\hline $\mathrm{S} 4 \mathrm{H3}$ & $6 / 5 / 86$ & 47 & 2.3 & 138 & 6.2 & .0 & 13.5 & 52 & 1.4 & 11,000 & 8,800 \\
\hline $\mathrm{S} 4 \mathrm{H} 5$ & $10 / 24 / 87$ & 108 & -- & 220 & 8.1 & .0 & 16.0 & 85 & -- & 200 & $<10$ \\
\hline S2H5 & $10 / 27 / 87$ & 85 & 6.8 & 250 & 7.9 & .0 & 17.0 & 93 & -- & 1,300 & 1,100 \\
\hline CL4 & $10 / 25 / 87$ & 81 & 6.2 & 242 & 8.2 & .0 & 15.0 & 85 & 1.5 & 200 & 30 \\
\hline CL5 & $10 / 25 / 87$ & 50 & 6.3 & 109 & 6.8 & .0 & 14.0 & 32 & 2.6 & 6,800 & 6,600 \\
\hline $\mathrm{S} 1 \mathrm{H} 4$ & $6 / 5 / 86$ & 51 & 3.7 & 112 & 6.5 & .0 & 13.7 & 36 & 2.1 & 1,400 & 940 \\
\hline SL 5 & $10 / 22 / 87$ & 101 & 1.3 & 273 & 8.2 & .0 & 16.0 & 122 & 1.4 & 500 & 390 \\
\hline SL7 & $10 / 28 / 87$ & 55 & 9.0 & 252 & 7.7 & .0 & 15.0 & 124 & .7 & 1,800 & 1,600 \\
\hline 201 & $6 / 18 / 87$ & 108 & -- & 600 & 8.3 & .0 & 15.0 & 189 & 5.5 & 15 & n.d. \\
\hline BL6 & $10 / 20 / 87$ & 103 & 6.4 & $2,100(\mathrm{sa})^{\mathrm{a}}$ & 8.1 & .0 & 15.5 & 250 & - & 400 & 140 \\
\hline SN6 & $10 / 17 / 87$ & 72 & 2.4 & 200 & 7.9 & .0 & 14.0 & 142 & -- & 2,000 & 2,000 \\
\hline \multicolumn{12}{|c|}{ Southern part of dunes } \\
\hline P41 & $3 / 5 / 87$ & 108 & 12.5 & 580 & 8.0 & .0 & 15.0 & 328 & -- & 690 & 140 \\
\hline P58 & $3 / 5 / 87$ & 110 & 24.3 & 400 & 8.5 & .0 & 13.0 & 234 & -- & 230 & $<10$ \\
\hline P56 & $3 / 5 / 87$ & 88 & 8.5 & $1,540(\mathrm{sa})$ & 7.8 & .0 & 13.0 & 388 & -- & 340 & $<10$ \\
\hline $\mathrm{P} 42$ & $3 / 4 / 87$ & 121 & 5.0 & $2,350(\mathrm{sa})$ & 7.5 & .0 & 12.5 & 426 & -- & 230 & $<10$ \\
\hline BB8 & $3 / 7 / 87$ & 86 & 4.1 & 360 & 8.5 & .0 & 13.5 & 176 & 5.5 & 60 & n.d. \\
\hline $\mathrm{HF} 2 \mathrm{H} 2$ & $6 / 6 / 86$ & 139 & -- & 1,100 (sa) & 7.7 & .0 & 13.7 & 380 & -- & 410 & 85 \\
\hline $\mathrm{P} 45$ & $3 / 14 / 86$ & 157 & -- & 330 & 7.7 & .0 & -- & 172 & -- & 460 & n.d. \\
\hline P46Y & $3 / 3 / 87$ & 128 & .7 & 382 & 8.5 & .0 & 13.5 & 200 & -- & 15 & n.d. \\
\hline SCP5C & $3 / 4 / 87$ & 70 & 10.0 & 320 & 7.4 & .0 & 16.0 & 180 & -- & 4,600 & 4,200 \\
\hline BB2 & $5 / 28 / 86$ & 85 & 5.8 & 220 & 7.7 & .0 & 13.5 & 108 & 5.6 & 84 & $<10$ \\
\hline $\mathrm{BB} 4$ & $5 / 29 / 86$ & 92 & 5.1 & 155 & 8.4 & .0 & 14.0 & 68 & 1.4 & 7 & n.d. \\
\hline SCP4C & $3 / 4 / 87$ & 101 & 13.2 & 260 & 8.2 & .0 & 14.0 & 144 & - & 140 & $\mathrm{n}, \mathrm{d}$. \\
\hline SCP2C & $3 / 3 / 87$ & 101 & 10.5 & 210 & 8.2 & .0 & 15.5 & 116 & -- & 310 & $<10$ \\
\hline SCP3B & $3 / 3 / 87$ & 86 & 4.0 & $\cdot 172$ & 8.5 & .0 & 15.0 & 82 & -- & 15 & n.d. \\
\hline SS2 & $3 / 6 / 87$ & 94 & -- & 930 & 8.2 & .0 & 13.5 & 426 & -- & 230 & $<10$ \\
\hline
\end{tabular}

\footnotetext{
${ }^{a}$ (sa) indicates water composition a result of mixing of freshwater and seawater from saltwater encroachment.
} 


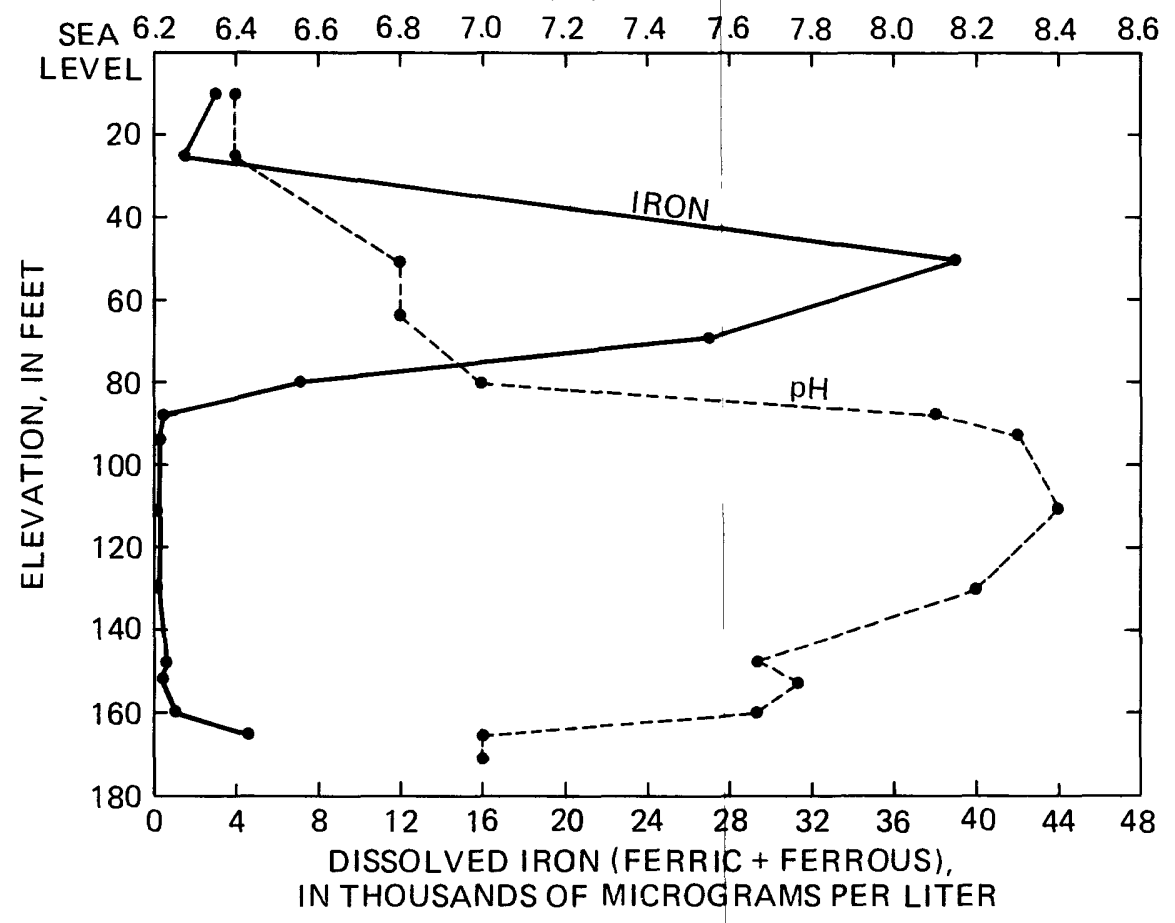

Figure 7.--Vertical profile of dissolved iron concentration and $\mathrm{pH}$ at closely spaced intervals of depth in water from piezometer B3, October 20-22, 1981.

One mechanism explaining the change in dissolved iron concentration and $\mathrm{pH}$ is the presence of shell fragments in the deeper sands (fig. 8). Shell material containing aragonite or calcite $\left(\mathrm{CaCO}_{3}\right)$ is a source of calcium and bicarbonate to the ground water according to the reaction,

$$
\mathrm{CaCO}_{3}+\mathrm{H}^{+} \rightarrow \mathrm{Ca}^{+2}+\mathrm{HCO}_{3}^{-} \text {. }
$$

Hydrogen ions are consumed by the dissolution of calcite and the $\mathrm{pH}$ rises. If calcite dissolves in the presence of $\mathrm{CO}_{2}$, the reaction is written as

$$
\mathrm{CaCO}_{3}+\mathrm{H}_{2} \mathrm{CO}_{3} \rightarrow \mathrm{Ca}^{+2}+2 \mathrm{HCO}_{3}^{-} \text {. }
$$

The higher the partial pressure of $\mathrm{CO}_{2}$, the greater is the amount of $\mathrm{H}_{2} \mathrm{CO}_{3}$ available for reaction with $\mathrm{CaCO}_{3}$. Therefore, the reaction proceeds farther to the right to achieve equilibrium. As $\mathrm{HCO}_{3}^{-}$concentrations and $\mathrm{pH}$ increase, dissolved iron concentration is greatly reduced. Where shell material is present, precipitation of siderite is a probable mechanism limiting iron concentrations in the deeper water. Precipitation of siderite $\left(\mathrm{FeCO}_{3}\right)$ occurs according to the reaction,

$$
\mathrm{Fe}^{+2}+\mathrm{HCO}_{3}^{-} \rightarrow \mathrm{FeCO}_{3}+\mathrm{H}^{+} .
$$

Identification of siderite in the dune aquifer is difficult due to the small quantities of siderite particles on sand grains and the inability of SEM-EDXRF analyses to detect carbon and oxygen. Siderite was found to occur as bladelike and globular crusts as well as small rhombohedral crystals in several sand samples examined. SEM analyses of samples from P58 and P60 (see p1. 1) at 130 and 50 feet below land surface, respectively, revealed crystals that were indicative of siderite. SEM photomicrographs for P58 and P60 show 

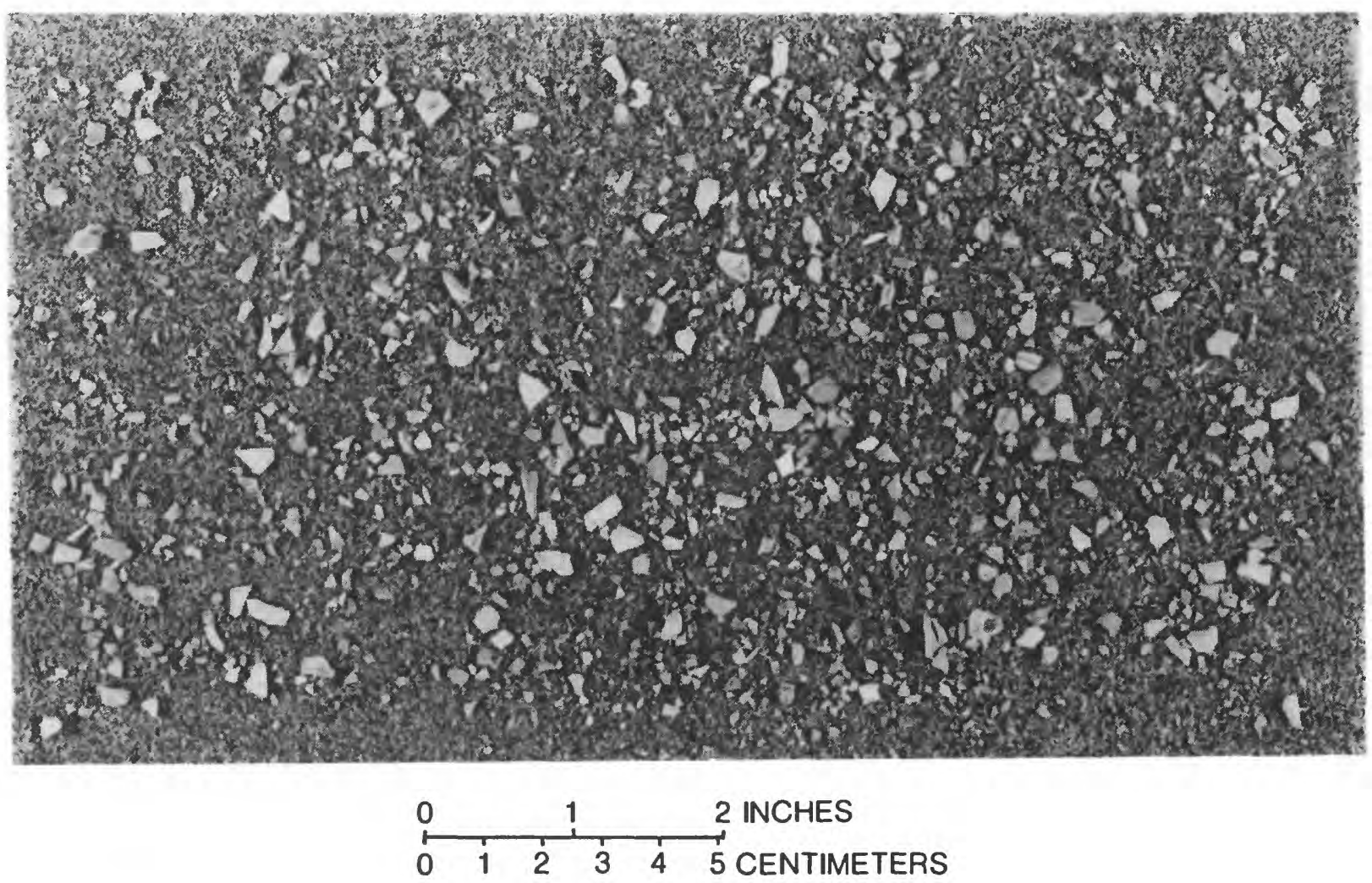

Figure 8.--Marine shell fragments in deep part of aquifer.

bladelike and globular crusts of siderite (fig. 9). The presence of siderite with similar morphology is supported by previous work (Magaritz and Luzier, 1985; Welton, 1984). Furthermore, Klein and Hurlbut (1985) describe authigenic siderite occurring in unit rhombohedrons or globular concretions.

Where hydrogen sulfide is present, ferrous sulfide will control aqueous iron concentrations. Bacterial reduction of sulfate results in the formation of ferrous sulfide according to the reaction,

$$
\mathrm{Fe}^{+^{2}}+2 \mathrm{SO}_{4}^{-2}+16 \mathrm{H}^{+}+14 \mathrm{e}^{-} \rightarrow \mathrm{FeS}_{2}+8 \mathrm{H}_{2} \mathrm{O} \text {. }
$$

Solid phases of authigenic ferrous sulfide were found to occur in the sands. For example, ferrous sulfide spheres formed on the surface of potassium feldspar and wood fragments are shown in figure 10. These spheres of ferrous sulfide were found in the deep part of the aquifer in the southern part of the dunes. In these waters the reduction of sulfate to sulfide is evident from the small sulfate concentrations (less than $1.0 \mathrm{mg} / \mathrm{L}$ ) observed for some water; for example, water from piezometers P45 and SCP2C. Most deep water in the northern and southern part of dunes has sulfate concentrations which are generally smaller than shallow water, but the sulfate concentration is sufficiently large in the deep water to indicate sulfate reduction is only partial.

In the deep part of the aquifer in the northern part of the dunes, shell fragments are sparse or exist only in thin layers near the base of the sands. Consequently, dissolved iron concentrations are small only near the base of 
A

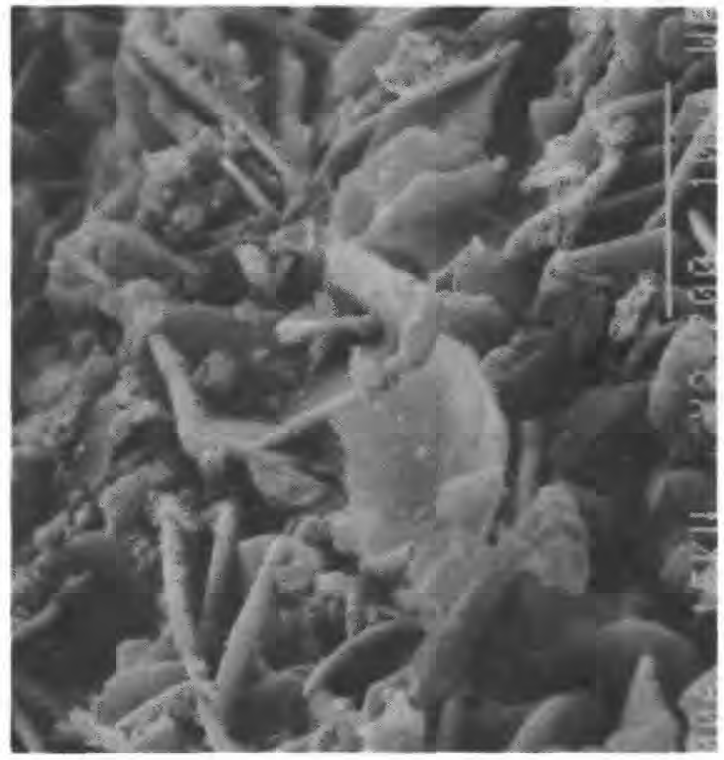

0 10 MICROMETERS

c

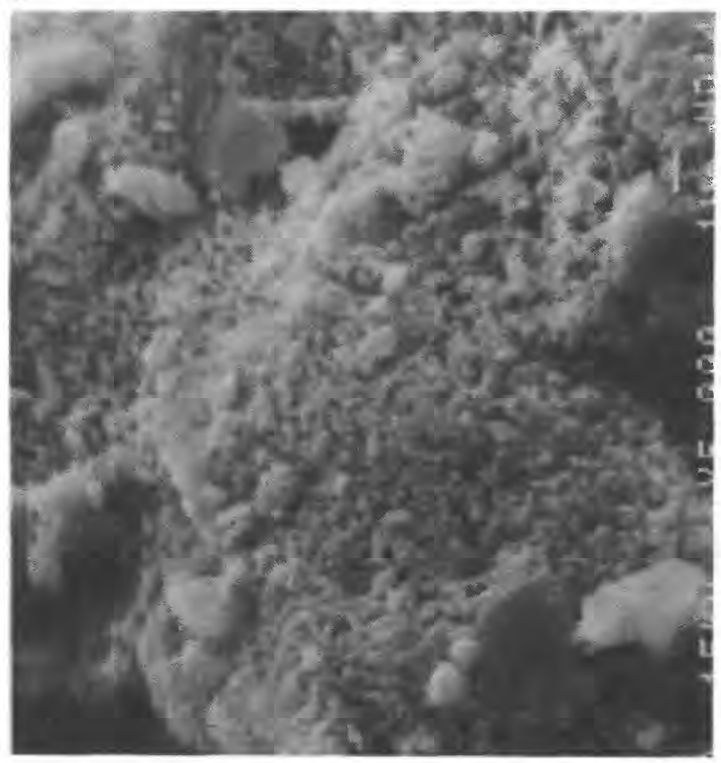

눈
B

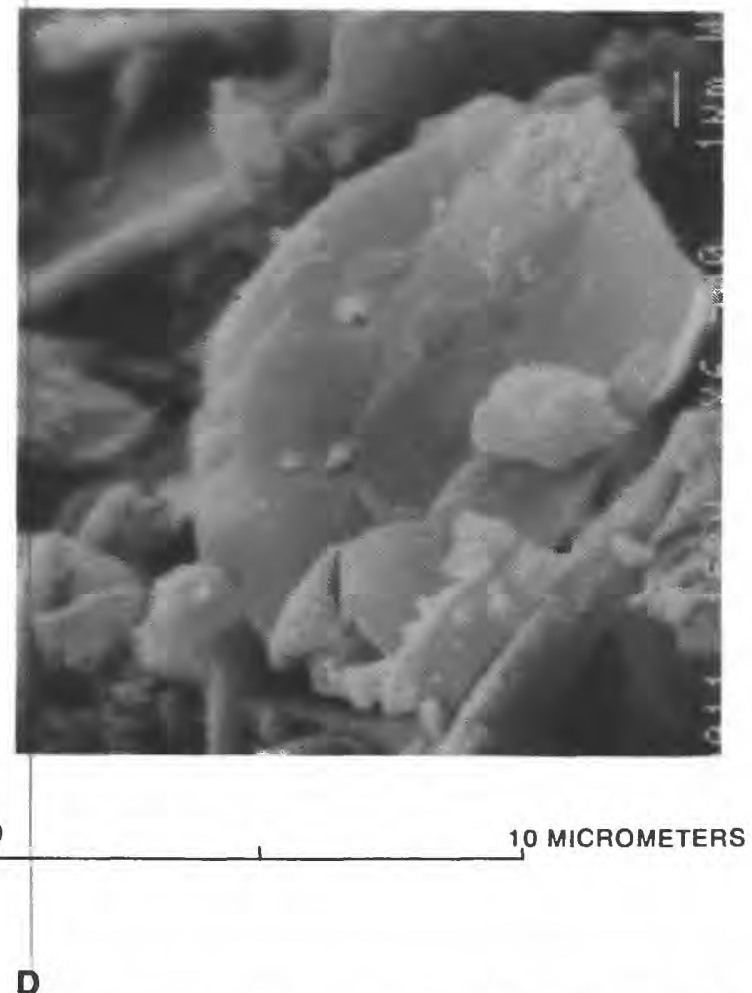

D

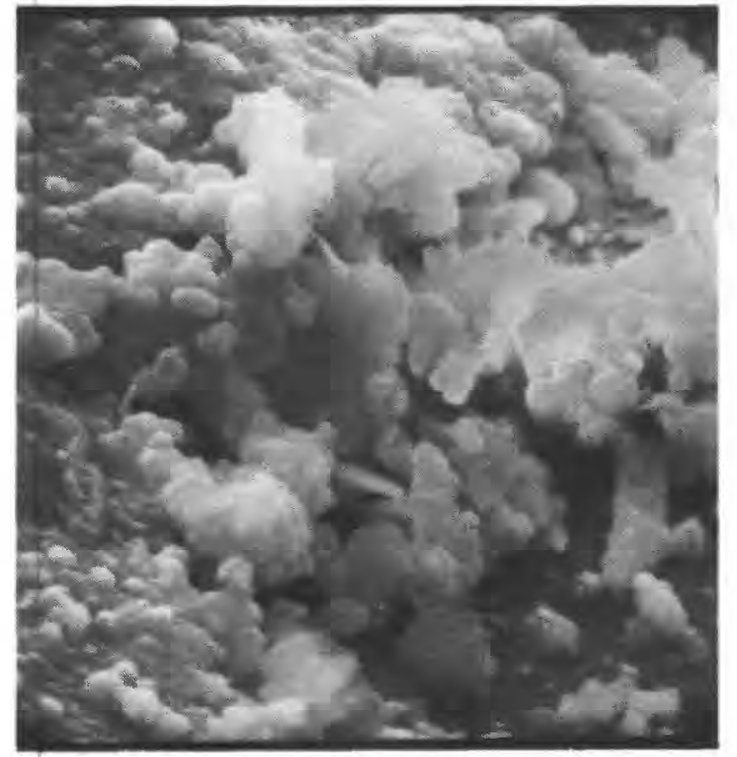

10 MICROMETERS

Figure 9.--Scanning electron micrographs showing authigenic siderite phases (scale bar in micrometers).

(A) Siderite crystals in the form of bladelike crusts (P58, -110 feet); (B) Siderite crystals (A, above )

at higher magnification; (C) Siderite crystals in the form of globular crusts (P58,-110 feet);

(D) Siderite crystals in the form of globular crusts (P60, -10 feet). 
A

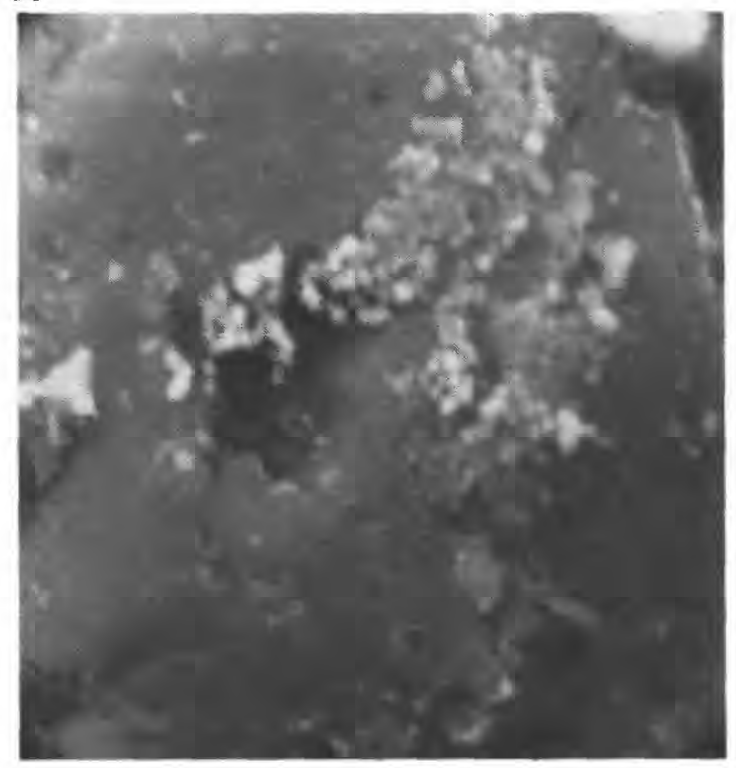

i

C

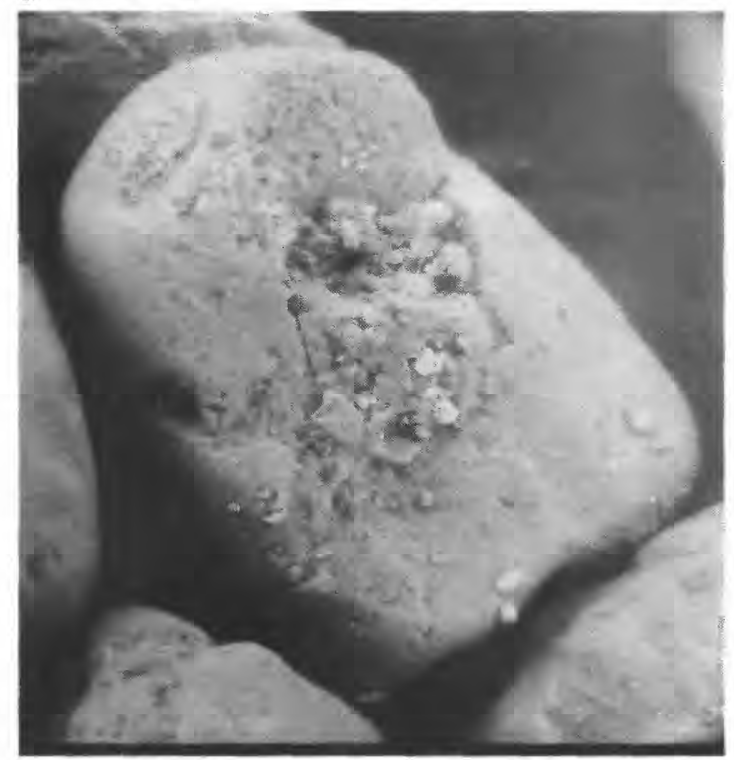

0
B

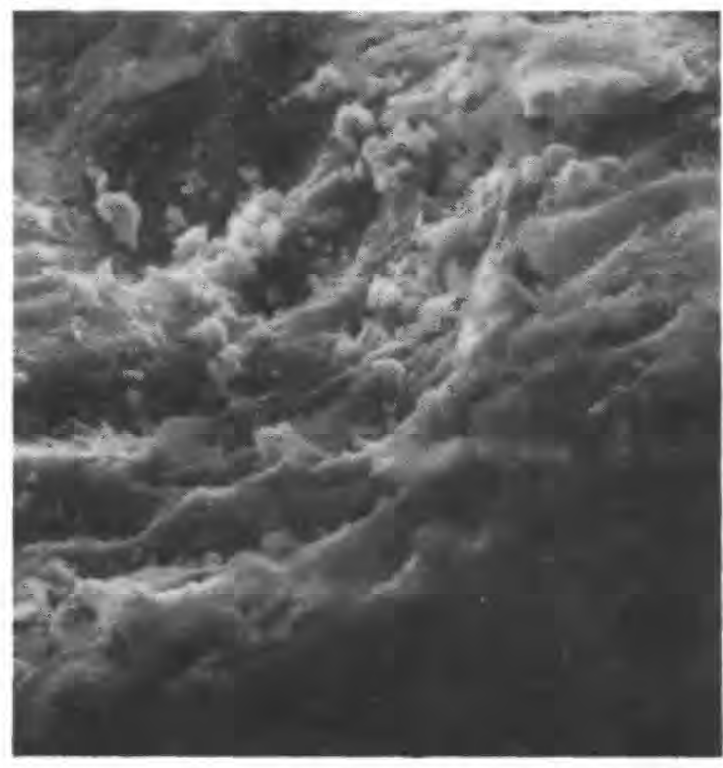

O., 10 MICROMETERS

D

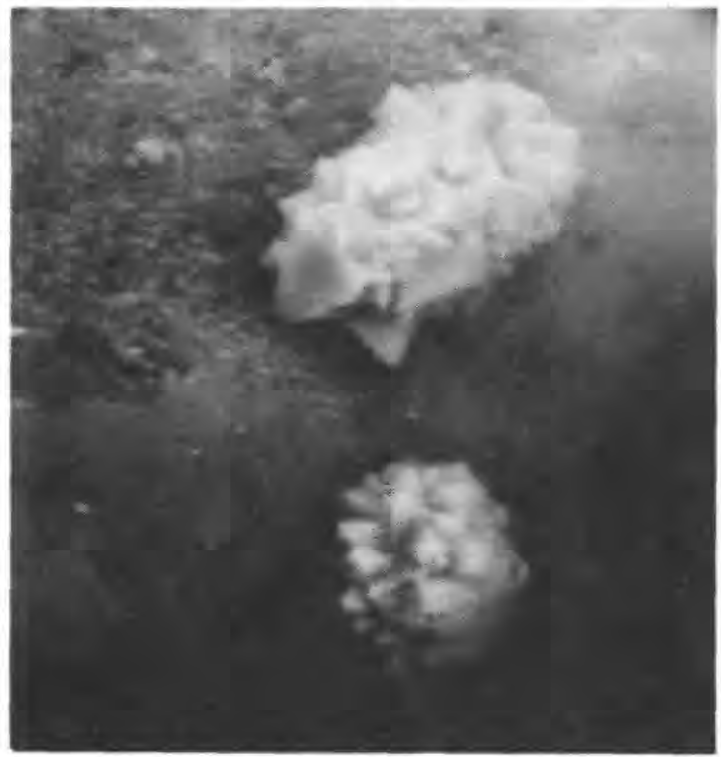

\& 10 MICROMETERS

Figure 10.--Scanning electron micrographs showing authigenic ferrous sulfide phases (scale bar in micrometers).

(A) Ferrous sulfide spheres on $\mathrm{K}$-feldspar grains (W53, -20 feet); (B) Ferrous sulfide spheres on wood

fragments (W53, -20 feet); (C) Ferrous sulfide spheres on $\mathrm{K}$-feldspar grains (W53, -80 feet);

(D) Ferrous sulfide spheres (C, above) at higher magnification. 
the dune-sand aquifer as shown at piezometer sites BL, CL, and S4 in table 7 . E1sewhere at four other piezometer sites (SL, S1, S2, SN) in the northern part of the dunes (see table 7 for respective nested piezometer names), iron concentrations ranged from 1,300 to $2,000 \mu \mathrm{g} / \mathrm{L}$ near the base of the sands.

Water was sampled from three sites with nested piezometers along a flow path in the northern part of the dunes (see fig. 6). S1, in the upgradient part of the flow path, is located in bare sand downslope from a bare sand ridge as shown in the hydrogeologic section A-A' (fig. 6). Water from the upper two piezometers at SI infiltrates only bare sand. Water from the lower two piezometers at S1 infiltrates, according to the flownet, a small area of forest upgradient in the flow path near Saunders Lake. The dissolved iron concentration from the shallowest piezometer is $100 \mu \mathrm{g} / \mathrm{L}$, and dissolved iron concentrations in the deeper water range from 1,100 to $1,400 \mu \mathrm{g} / \mathrm{L}$. These larger concentrations are caused by a combination of factors: the two most probable are an increase in iron concentration due to chemical weathering of sands with increased residence time, and some influence of upgradient forest.

At S2, water from the second and third piezometers at elevations of -19 and - 31 feet infiltrates only bare sand (see fig. 6); the iron concentrations are 1,100 and $2,200 \mu \mathrm{g} / \mathrm{L}$, respectively. Dissolved iron concentration in water from the deepest piezometer at the base of the sand at S2 is $1,300 \mu \mathrm{g} / \mathrm{L}$ (see fig. 6). Site CL is located in the most downgradient part of the flow path. The dissolved iron concentration is $200 \mu \mathrm{g} / \mathrm{L}$ near the base of the sands at -81 feet elevation, (CL4), and the iron concentration is $6,800 \mu \mathrm{g} / \mathrm{L}$ at -50 feet elevation (CL5, see fig. 6). One explanation for the large difference in dissolved iron concentration between these two depths may be the passage of water through shell fragments at deeper depths, resulting in smal1 concentrations of iron. Small concentrations of dissolved iron near the base of sands are observed also at sites BL and S4 (see table 7).

In general, concentrations of dissolved iron increase with depth in the northern part of the dunes where water had infiltrated primarily bare sand. Large iron concentrations of $11,000 \mu \mathrm{g} / \mathrm{L}$ (S4H3) and $6,800 \mu \mathrm{g} / \mathrm{L}$ (CL5) are found at downgradient sites indicating iron concentrations increase with increased residence time (see table 7). However, concentrations of dissolved iron are not directly related to residence time, as shown by differences in iron concentrations at comparable depths at upgradient sites S1 and S2 (see fig. 6). Variation in iron concentration at depth may be due to differences in the concentrations of carbonate and bicarbonate from marine shells and sulfide from sulfate reduction. Variable amounts of organic matter buried at depth and variation in the proportion of water infiltrating bare sand, shell fragments, and forest could all explain differences in iron concentrations with depth and residence time.

\section{Solubility-Equilibrium Calculations and Stable Isotope Chemistry}

Saturation indices (SI) for siderite and calcite were determined to help substantiate findings discussed thus far. SI values were computed using the WATEQF aqueous speciation model (Plummer and others, 1984).

In most shallow waters, the SI values for siderite indicate undersaturation. Water that had infiltrated areas of lodgepole pine forest (forest of both old and coastal deflation plains) has a median dissolved ferrous iron concentration of $7,000 \mu \mathrm{g} / \mathrm{L}$ and is undersaturated with respect to calcite at a11 12 sites and to siderite for 11 of 12 sites (table 8). The pH values 
Table 7.--Dissolved iron concentration and $\mathrm{pH}$ in vertical profile at sites located in the northern part of the dunes

[Nested piezometer sites with lowest elevation near base of sands except site SN.]

\begin{tabular}{|c|c|c|c|c|}
\hline Site & $\begin{array}{l}\text { Nested } \\
\text { piezo- } \\
\text { meters }\end{array}$ & $\begin{array}{l}\text { Elevation of } \\
\text { bottom of we } 11 \\
\text { opening, in feet } \\
\text { above or below } \\
\text { sea level }\end{array}$ & $\begin{array}{l}\mathrm{pH} \\
\text { in } \\
\text { units }\end{array}$ & $\begin{array}{l}\text { Iron, } \\
\text { ferric }+ \\
\text { ferrous } \\
\text { (micrograms } \\
\text { per liter) }\end{array}$ \\
\hline \multicolumn{5}{|c|}{ old deflation plain } \\
\hline SL & $\begin{array}{l}\text { SL6 } \\
\text { SL9 } \\
\text { SL8 } \\
\text { SL7 }\end{array}$ & $\begin{array}{r}28 \\
-9 \\
-33 \\
-55\end{array}$ & $\begin{array}{l}6.0 \\
6.6 \\
6.5 \\
7.7\end{array}$ & $\begin{array}{r}230 \\
4,600 \\
4,100 \\
1,800\end{array}$ \\
\hline S1 & $\begin{array}{l}\text { S1H1 } \\
\text { S1H2 } \\
\text { S1H3 } \\
\text { S1H4 }\end{array}$ & $\begin{array}{r}24 \\
-1 \\
-18 \\
-51\end{array}$ & $\begin{array}{l}6.2 \\
6.0 \\
6.1 \\
6.5\end{array}$ & $\begin{array}{r}100 \\
1,200 \\
1,100 \\
1,400\end{array}$ \\
\hline s2 & $\begin{array}{l}\mathrm{S} 2 \mathrm{H} 4 \\
\mathrm{~S} 2 \mathrm{H} 1 \\
\mathrm{~S} 2 \mathrm{H} 2 \\
\mathrm{~S} 2 \mathrm{H} 3 \\
\mathrm{~S} 2 \mathrm{H} 5\end{array}$ & $\begin{array}{r}22 \\
10 \\
-19 \\
-31 \\
-85\end{array}$ & $\begin{array}{l}5.8 \\
6.1 \\
6.2 \\
6.2 \\
7.9\end{array}$ & $\begin{array}{r}310 \\
430 \\
1,100 \\
2,200 \\
1,300\end{array}$ \\
\hline \multicolumn{5}{|c|}{ Coastal deflation plain } \\
\hline SN & $\begin{array}{l}\text { SN3 } \\
\text { SN5 } \\
\text { SN6 }\end{array}$ & $\begin{array}{r}2 \\
-34 \\
-72\end{array}$ & $\begin{array}{l}6.5 \\
7.1 \\
7.9\end{array}$ & $\begin{array}{r}34,000 \\
9,800 \\
2,000\end{array}$ \\
\hline$B L$ & $\begin{array}{l}\text { BL3 } \\
\text { BL5 } \\
\text { BL6 }\end{array}$ & $-38^{.5}$ & $\begin{array}{l}6.6 \\
7.5 \\
8.1\end{array}$ & $\begin{array}{r}27,000 \\
4,200 \\
400\end{array}$ \\
\hline CL & $\begin{array}{l}\text { CL1 } \\
\text { CL5 } \\
\text { CL4 }\end{array}$ & $\begin{array}{r}17 \\
-50 \\
-81\end{array}$ & $\begin{array}{l}6.2 \\
6.8 \\
8.2\end{array}$ & $\begin{array}{r}1,600 \\
6,800 \\
200\end{array}$ \\
\hline s4 & $\begin{array}{l}\mathrm{S} 4 \mathrm{H} 4 \\
\mathrm{~S} 4 \mathrm{H} 1 \\
\mathrm{~S} 4 \mathrm{H} 2 \\
\mathrm{~S} 4 \mathrm{H} 3 \\
\mathrm{~S} 4 \mathrm{H} 5\end{array}$ & $\begin{array}{r}9 \\
-3 \\
-18 \\
-47 \\
-108\end{array}$ & $\begin{array}{l}5.7 \\
6.0 \\
6.1 \\
6.2 \\
8.1\end{array}$ & $\begin{array}{r}3,300 \\
690 \\
570 \\
11,000 \\
200\end{array}$ \\
\hline
\end{tabular}


Table 8.-- Chemical data and saturation indices for shallow ground water

[See plate 1 for location of piezometers; the saturation index, SI, is the logarithm of the quotient of the ion-activity product divided by the equilibrium constant; a positive si indicates supersaturation and a negative SI undersaturation with respect to the mineral; -- = no data; $n$.d. = No ferrous iron detected in solution; and 10 micrograms per liter used in SI calculation.]

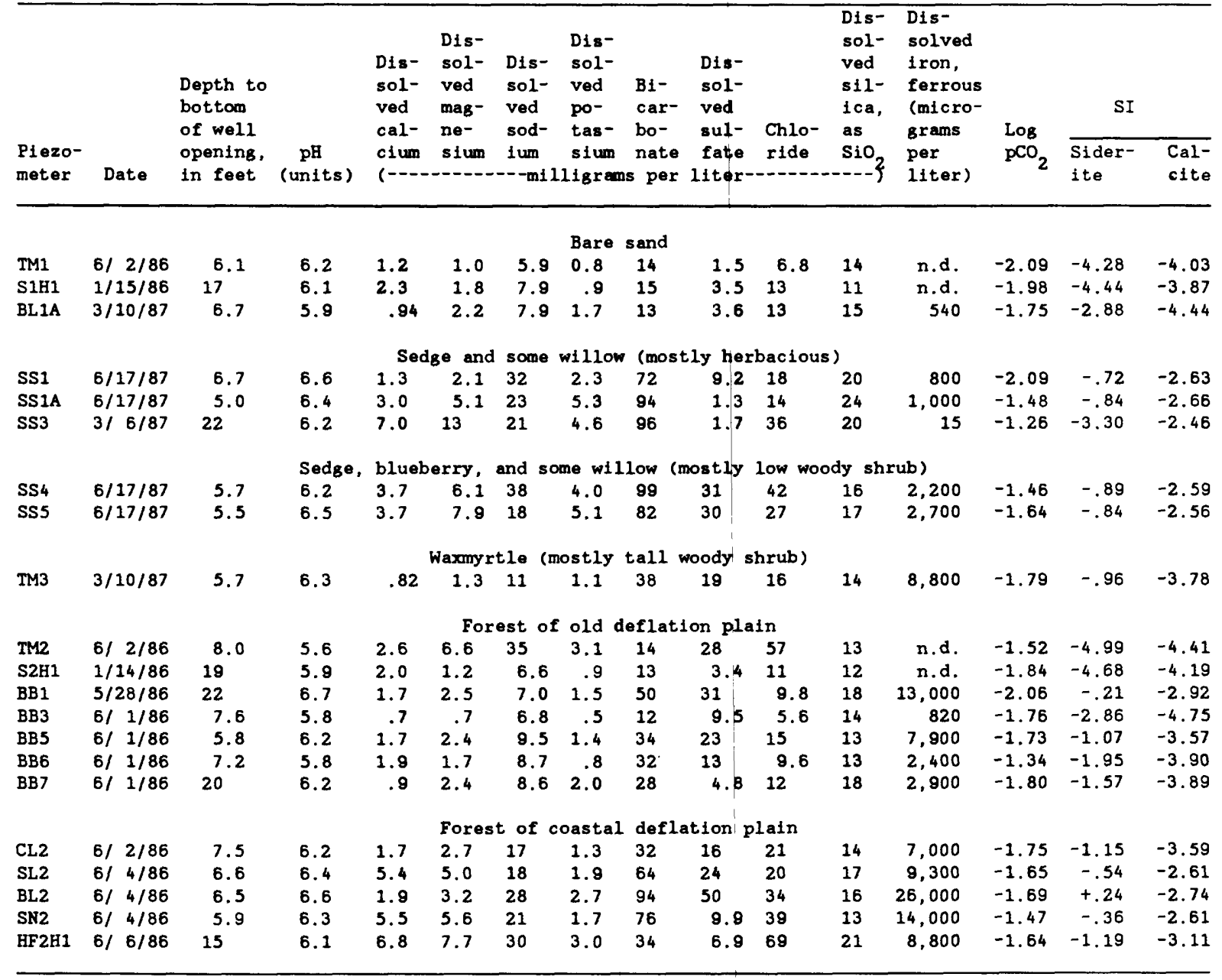

range from 5.6 to 6.6 , and bicarbonate concentrations are 12 to $94 \mathrm{mg} / \mathrm{L}$. With $\mathrm{pH}$ and bicarbonate values such as these, siderite would not be formed unless iron concentrations were maintained at high levels such as BL2, the only water showing supersaturation with respect to siderite.

Water in the deep part of the aquifer is generally low in ferrous iron and high in $\mathrm{pH}$. Deep water from the southern part of the dunes is supersaturated with respect to calcite for 9 of 15 sites (table 9), which causes bicarbonate ion and $\mathrm{pH}$ to increase in solution providing conditions favorable for siderite precipitation. In contrast, deep water in the northern part of the dunes is undersaturated with respect to calcite for 9 of 11 sites, and $\mathrm{pH}$ values and bicarbonate concentration are smaller than in the southern part of the dunes (table 9). 
Table 9.--Chemical data and saturation indices for deep ground water

[See plate 1 for location of piezometers; the saturation index, SI, is the logarithm of the quotient of the ionactivity product divided by the equilibrium constant; a positive SI indicates supersaturation and a negative SI undersaturation with respect to the mineral; -- = no data; $n . d$. = No ferrous iron detected in solution; and 10 micrograms per liter used in SI calculation.]

\begin{tabular}{|c|c|c|c|c|c|c|c|c|c|c|c|c|c|c|c|}
\hline & & $\begin{array}{l}\text { Elevation } \\
\text { of bottom } \\
\text { of well } \\
\text { opening } \\
\text { (feet }\end{array}$ & & $\begin{array}{l}\text { Dis- } \\
\text { sol- } \\
\text { ved } \\
\text { cal- }\end{array}$ & $\begin{array}{l}\text { Dis- } \\
\text { sol- } \\
\text { ved } \\
\text { mag- } \\
\text { ne- }\end{array}$ & $\begin{array}{l}\text { Dis- } \\
\text { sol- } \\
\text { ved } \\
\text { sod- }\end{array}$ & $\begin{array}{l}\text { Dis- } \\
\text { sol- } \\
\text { ved } \\
\text { po- } \\
\text { tas- }\end{array}$ & $\begin{array}{l}\text { Bi- } \\
\text { car- } \\
\text { bo- }\end{array}$ & $\begin{array}{l}\text { Dis- } \\
\text { sol- } \\
\text { ved } \\
\text { sul- }\end{array}$ & & $\begin{array}{l}\text { Dis- } \\
\text { sol- } \\
\text { ved } \\
\text { sil- } \\
\text { ica, } \\
\text { as }\end{array}$ & $\begin{array}{l}\text { Dis- } \\
\text { solved } \\
\text { iron, } \\
\text { ferrous } \\
\text { (micro } \\
\text { grams }\end{array}$ & SI & & \begin{tabular}{l}
\multicolumn{1}{c}{$\delta$} \\
carbon \\
-13 \\
(parts \\
per
\end{tabular} \\
\hline $\begin{array}{l}\text { Piezo- } \\
\text { meter }\end{array}$ & Date & $\begin{array}{l}\text { below sea } \\
\text { level) }\end{array}$ & $\underset{\text { (units) }}{\mathrm{pH}}$ & cium & sium & ium & $\begin{array}{l}\text { sium } \\
\text { igrams }\end{array}$ & $\begin{array}{l}\text { nate } \\
\text { per }\end{array}$ & $\begin{array}{l}\text { fate } \\
\text { liter- }\end{array}$ & ride & $\mathrm{SiO}_{2}$, & $\begin{array}{l}\text { per } \\
\text { liter) }\end{array}$ & $\begin{array}{l}\text { Sider- } \\
\text { ite }\end{array}$ & $\begin{array}{l}\text { Cal- } \\
\text { cite }\end{array}$ & $\begin{array}{l}\text { thou- } \\
\text { sand) }\end{array}$ \\
\hline
\end{tabular}

$\begin{array}{lrr}\text { TM4 } & 3 / 6 / 87 & 105 \\ \text { S4H3 } & 1 / 9 / 86 & 47 \\ \text { S4H5 } & 10 / 24 / 87 & 108 \\ \text { S2H5 } & 10 / 27 / 87 & 86 \\ \text { CL4 } & 10 / 25 / 87 & 81 \\ \text { CL5 } & 10 / 25 / 87 & 50 \\ \text { S1H4 } & 1 / 15 / 86 & 62 \\ \text { SL5 } & 10 / 22 / 87 & 101 \\ \text { SL7 } & 10 / 28 / 87 & 55 \\ \text { 201 } & 6 / 18 / 87 & 108 \\ \text { BL6 } & 10 / 20 / 87 & 103 \\ \text { SN6 } & 10 / 17 / 87 & 72\end{array}$

$\begin{array}{rccr}7.5 & 3.3 & 5.8 & 17 \\ 6.4 & 3.7 & 2.6 & 11 \\ 8.1 & -- & -- & -- \\ 7.9 & 13 & 2.2 & 33 \\ 8.2 & 5.4 & 2.2 & 42 \\ 6.8 & 2.1 & 1.8 & 12 \\ 6.6 & 2.0 & 1.1 & 16 \\ 8.2 & 26 & 3.9 & 22 \\ 7.7 & 22 & 3.5 & 43 \\ 8.3 & 47 & 3.0 & 97 \\ 8.1 & 12 & 13 & 390 \\ 7.9 & 21 & 12 & 12\end{array}$

$\begin{array}{rrrr}4.8 & 58 & 3.5 & 15 \\ 1.1 & 49 & 1.2 & 15 \\ -- & -- & -- & -- \\ 2.6 & 93 & 4.8 & 30 \\ 3.3 & 85 & 1.4 & 32 \\ 1.1 & 32 & 17 & 15 \\ 1.4 & 31 & 5.1 & 19 \\ 2.9 & 122 & 10 & 20 \\ 3.0 & 124 & 22 & 30 \\ 5.8 & 189 & 2.6 & 83 \\ 14 & 250 & 49 & 450 \\ 3.6 & 142 & 2.4 & 12\end{array}$

$\begin{array}{ll}15 & 19 \\ 15 & 23 \\ -- & -- \\ 30 & 16 \\ 32 & 20 \\ 15 & 20 \\ 19 & 13 \\ 20 & 32 \\ 30 & 23 \\ 83 & 21 \\ 450 & 18 \\ 12 & 30\end{array}$

$<10$
8,800
$<10$
1,100
30
6,600
940
390
1,600
n.d.
140
2,000

-2.40
-.77
--
+.29
-1.07
-.54
-1.62
+.21
+.29
-1.15
-.18
+.63

$\begin{array}{ll}-1.72 & -21.1 \\ -2.96 & -21.5 \\ -- & -15.2 \\ -.52 & -15.2 \\ -.66 & -16.1 \\ -2.88 & -- \\ -3.11 & -- \\ +.16 & -15.6 \\ -.42 & -17.8 \\ +.66 & -12.4 \\ -.13 & -13.8 \\ -.19 & -19.1\end{array}$

$\begin{array}{llr}\text { P41 } & 3 / 5 / 87 & 144 \\ \text { P58 } & 3 / 5 / 87 & 110 \\ \text { P56 } & 3 / 5 / 87 & 88 \\ \text { P42 } & 3 / 4 / 87 & 121 \\ \text { BB8 } & 3 / 7 / 87 & 86 \\ \text { HF2H2 } & 6 / 6 / 86 & 139 \\ \text { P45 } & 3 / 14 / 86 & 157 \\ \text { P46Y } & 3 / 3 / 87 & 128 \\ \text { SCP5C } & 3 / 4 / 87 & 70 \\ \text { BB2 } & 5 / 29 / 86 & 85 \\ \text { BB4 } & 5 / 29 / 86 & 92 \\ \text { SCP4C } & 3 / 4 / 87 & 101 \\ \text { SCP2C } & 3 / 3 / 87 & 101 \\ \text { SCP3B } & 3 / 3 / 87 & 86 \\ \text { SS2 } & 3 / 6 / 87 & 94\end{array}$

$\begin{array}{rccccr}8.0 & 21 & 12 & 150 & 12 & 328 \\ 8.5 & 23 & 12 & 41 & 43 & 234 \\ 7.8 & 46 & 32 & 200 & 22 & 388 \\ 7.5 & 5.2 & 10 & 480 & 20 & 426 \\ 8.5 & 50 & 10 & 13 & 4.8 & 176 \\ 7.7 & 28 & 21 & 160 & 17 & 380 \\ 7.7 & 16 & 16 & 24 & 13 & 172 \\ 8.5 & 32 & 17 & 17 & 14 & 200 \\ 7.4 & 47 & 3.7 & 13 & 3.2 & 180 \\ 7.7 & 30 & 2.2 & 8.9 & 2.5 & 108 \\ 8.4 & 17 & 1.5 & 9.2 & 3.7 & 68 \\ 8.2 & 35 & 5.1 & 11 & 7.6 & 144 \\ 8.2 & 24 & 4.4 & 8.6 & 8.9 & 116 \\ 8.5 & 26 & .83 & 6.8 & 3.0 & 84 \\ 8.2 & .44 & .80 & 210 & 4.6 & 426\end{array}$

$\begin{array}{ccc}5.2 & 140 & 21 \\ 1.7 & 9.6 & 23 \\ 2.6 & 310 & 25 \\ 10 & 590 & 27 \\ 4.8 & 28 & 28 \\ 3.7 & 160 & 23 \\ .8 & 33 & 18 \\ 1.6 & 23 & .5 \\ 4.3 & 17 & 32 \\ 3.0 & 13 & 35 \\ 4.0 & 8.6 & 23 \\ 1.8 & 14 & 24 \\ .9 & 11 & 25 \\ 3.4 & 12 & 24 \\ 1.9 & 160 & 15\end{array}$

$\begin{array}{rr}140 & -.10 \\ <10 & -.92 \\ <10 & -1.49 \\ <10 & -1.79 \\ \text { n.d. } & -1.04 \\ 85 & -.61 \\ \text { n.d. } & -1.81 \\ \text { n.d. } & -.98 \\ 4.200 & +.60 \\ <10 & -1.98 \\ \text { n.d. } & -1.47 \\ \text { n.d. } & -1.37 \\ <10 & -1.41 \\ \text { n.d. } & -1.27 \\ <10 & -1.10\end{array}$

$\begin{array}{ll}+.20 & -- \\ +.60 & -- \\ +.33 & -- \\ -.91 & -- \\ +.82 & -11.6 \\ +.06 & -- \\ -.44 & -16.6 \\ +.68 & -- \\ -.22 & -- \\ -.34 & - \\ -.07 & -- \\ +.33 & -- \\ +.11 & -- \\ +.30 & -- \\ -1.30 & --\end{array}$

Although most of the water in the deep part of the aquifer is saturated with respect to calcite, SI values indicate that siderite is not precipitating in all parts of the deep aquifer. Siderite precipitation is most likely to occur in the part of the aquifer where bicarbonate and ferrous iron concentrations are relatively large to maintain supersaturation with respect to siderite. Examples of deep water supersaturated with respect to siderite are from piezometers S2H5, SL5, SL7, SN6, and SCP5C at elevations from -101 to -55 feet (table 9). Most water that is substantially undersaturated with respect to siderite occurs where ferrous iron concentrations are small (less than $10 \mu \mathrm{g} / \mathrm{L})$. To attain theoretical saturation with respect to siderite would require in these waters that ferrous iron concentration with the same bicarbonate concentration be increased from their small values of less than 10 to about $500 \mu \mathrm{g} / \mathrm{L}$. It may be that the undersaturation is brought about by ferrous sulfide precipitation keeping the ferrous iron concentration below saturation of siderite. 
Water in the deep part of the aquifer in the southern dunes was sampled at closely spaced intervals in piezometer B3 (see p1. 1). Water becomes saturated with respect to siderite as calcite saturation is initially approached (fig. 11) and $\mathrm{pH}$ increases with depth (see fig. 7). Siderite then becomes greatly undersaturated from -90 to -130 feet elevation, and conversely from -156 to -171 feet elevation becomes supersaturated. Changes in siderite SI values with depth may be the result of competition between siderite and ferrous sulfide phases removing iron from solution. In this particular case, siderite at -90 to -130 feet elevation may not be forming because ferrous sulfide is too insoluble, and it keeps ferrous iron concentration below saturation of siderite. When ferrous sulfide precipitates, siderite will form only if the total iron concentration is in excess of total sulfide. One possible reaction of sulfate reduction in the presence of siderite to form ferrous sulfide is the following:

$$
7 \mathrm{CH}_{2} \mathrm{O}+2 \mathrm{FeCO}_{3}+4 \mathrm{SO}_{4}^{-2} \rightarrow 2 \mathrm{FeS}_{2}+8 \mathrm{HCO}_{3}^{-}+\mathrm{H}_{2} \mathrm{CO}_{3}+2 \mathrm{H}_{2} \mathrm{O} \text {. }
$$

As sulfide is formed from sulfate reduction, ferrous iron concentration is lowered to where siderite is unstable and dissolves, and subsequently the iron precipitates as a sulfide.

Stable isotopes of carbon were used to determine the source of bicarbonate. Marine carbonates typically have a $\delta$ carbon-13 value (see Stable Isotope Reporting Units, p. 64) of $0.1 \pm 2.8$, whereas carbonates derived from the oxidation of organic carbon typicaliy have a $\delta$ carbon-13 value of $-25 \pm 5$ (Rightmire and Hanshaw, 1973). Water dissolving marine shell fragments (less negative $\delta$ carbon-13 values) has larger bicarbonate concentration and $\mathrm{pH}$ as shown in figures 12 and 13, respectively. Two deep water samples in the

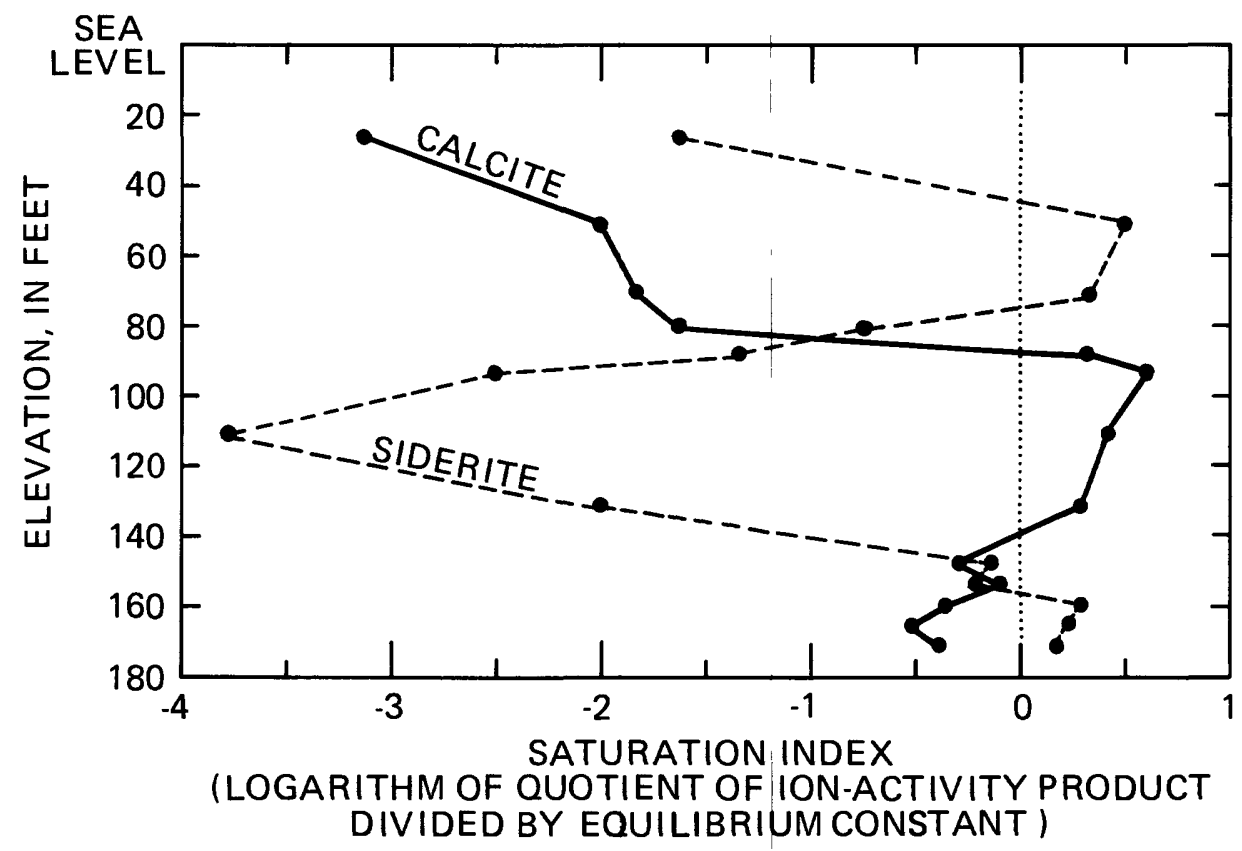

Figure 11.--Vertical profile of calcite and siderite saturation index at closely spaced intervals of depth in water from piezometer B3, October 20-22, 1981. 


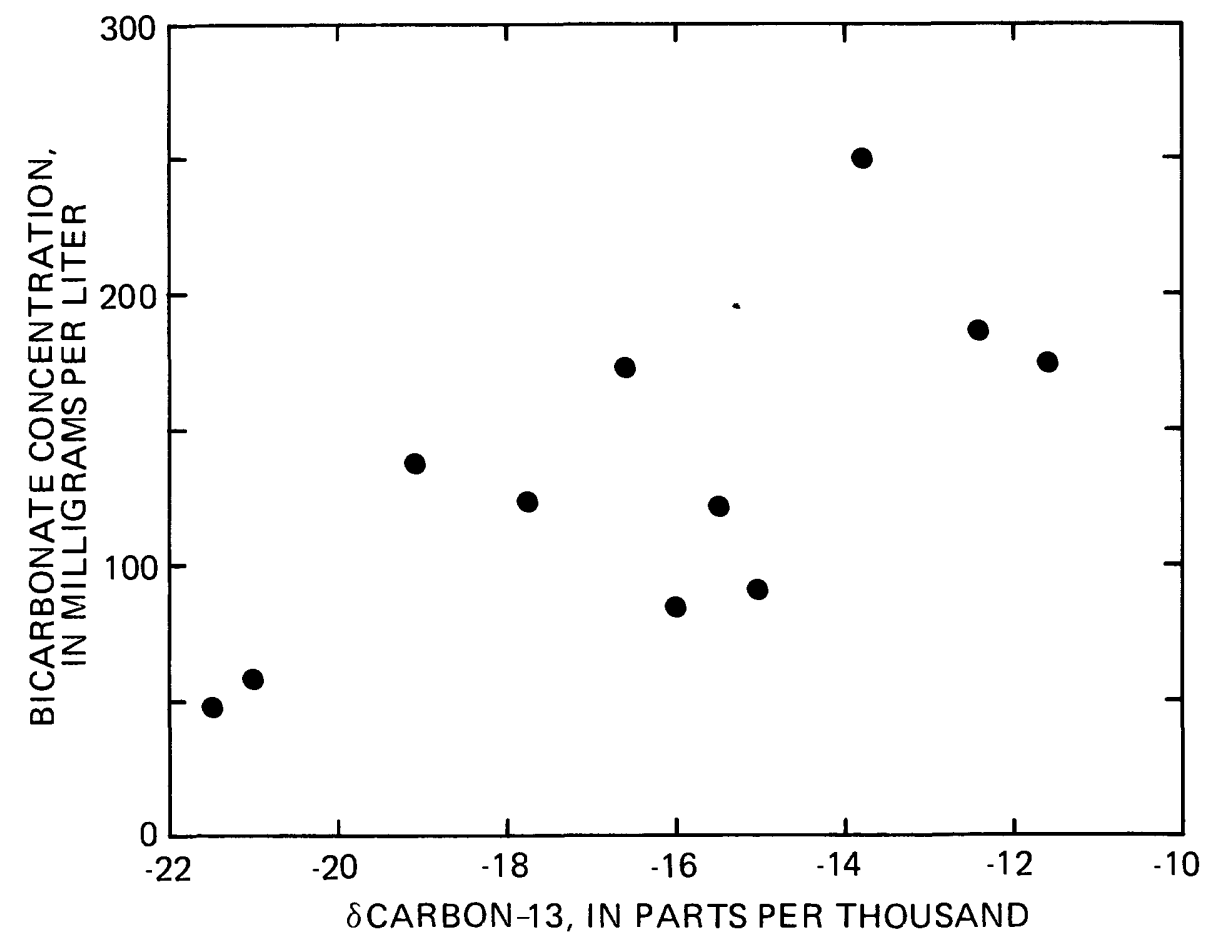

Figure 12.--Relation between concentration of bicarbonate and $\delta$ carbon-13 in the deep part of the dune-sand aquifer.

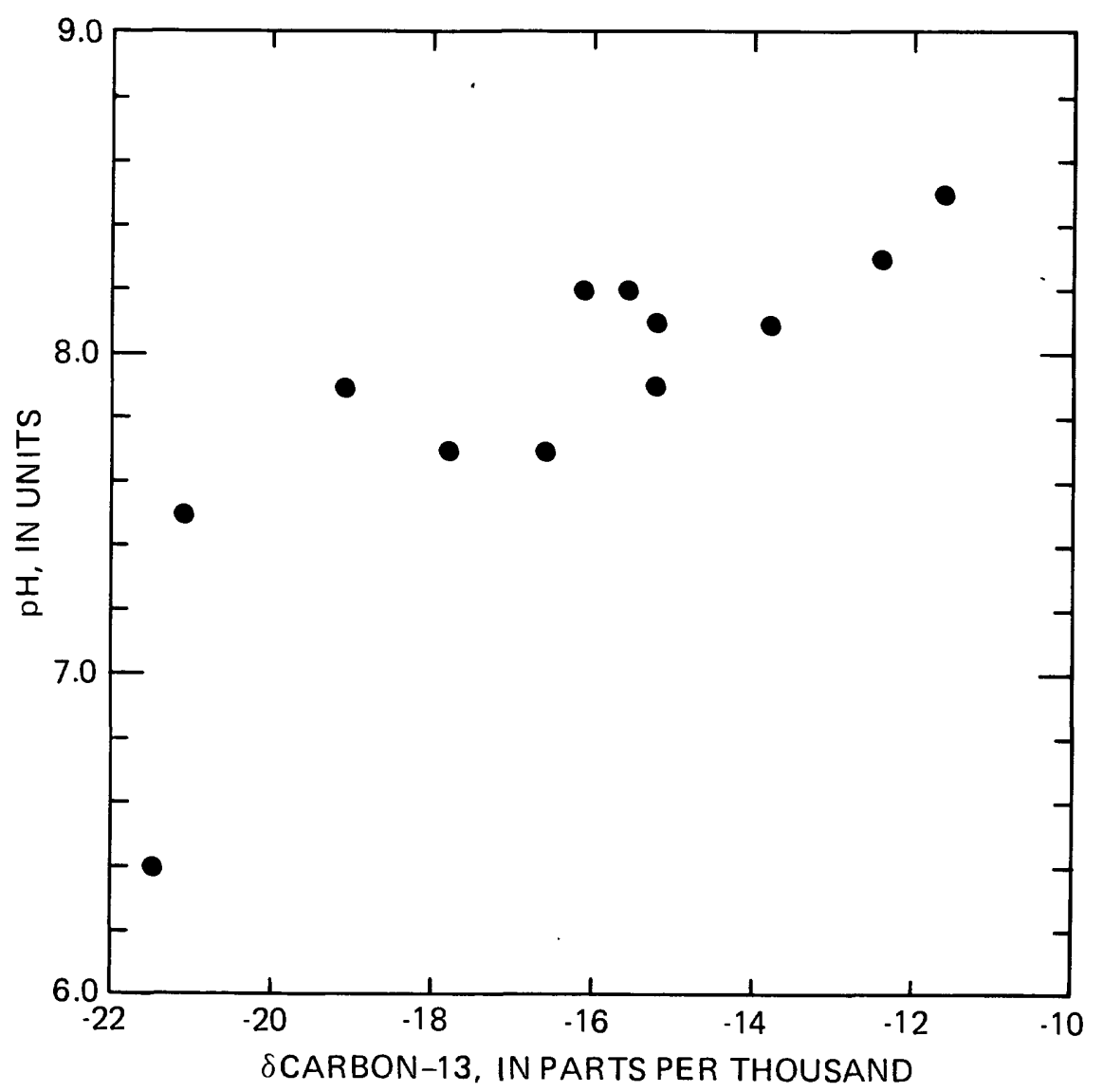

Figure 13.--Relation between pH and $\delta$ carbon-13 in the deep part of the dune-sand aquifer. 
northern dunes (S4H3 and TM4) had a $\delta$ carbon-13 value of -21.5 and -21.1 , respectively (table 9), indicating that the water contained only bicarbonate derived from plant- $\mathrm{CO}_{2}$-produced carbon and not bicarbonate dissolved from marine shells. These two water samples are greatly undersaturated with respect to calcite and should derive little or no bicarbonate from dissolution of shell material. Water from 10 sites at or oversaturated with respect to calcite has a $\delta$ carbon-13 ranging from -11.6 to -19.1 , which indicates a mixture of bicarbonate from plant: $\mathrm{CO}_{2}$-produced and marine shell sources.

\section{INFLUENCE OF GROUND-WATER PUMPING ON DISSOLVED IRON CONCENTRATIONS}

In the 1950's, the ground-water resource of the dunes was first explored and developed by the Pacific Power and Light Company. The original design for full development of the dunes aquifer was for 64 wells, extending from the northern part of the present well field to Tenmile Creek (see p1. 1), which would produce $30 \mathrm{Mgal} / \mathrm{d}$. Ground-water production from the dunes aquifer began in 1961 with six wells pumping a total of $2 \mathrm{Mgal} / \mathrm{d}$ to supply a pulpmill. The dunes well field was acquired by the Coos Bay-North Bend Water Board in 1968 and expanded. By 1970, 18 wells were in operation. Two new wells were constructed in 1979 and 1980. Currently, there are 6 production wells in operation in a west field and 14 wells in an east well field (see p1. 1). Wel1 49 was abandoned and a new wel1 49A, located a few feet from well 49 , became operational in 1985. A summary of the operational history of the wells follows :

\begin{tabular}{|c|c|c|c|}
\hline We11 & $\begin{array}{l}\text { Well } \\
\text { field }\end{array}$ & $\begin{array}{c}\text { Year of } \\
\text { construction }\end{array}$ & $\begin{array}{c}\text { Year of } \\
\text { operation }\end{array}$ \\
\hline $41,42,43,44,45,46$ & west & 1968 & 1970 \\
\hline $47,48,49^{a}$ & east & 1957 & 1961 \\
\hline $50,51,52$ & east & 1960 & 1961 \\
\hline $53,54,55,56,57,58$ & east & 1968 & 1970 \\
\hline 59 & east & 1979 & 1980 \\
\hline 60 & east & 1980 & 1980 \\
\hline $49 A$ & east & 1985 & 1985 \\
\hline
\end{tabular}

We11 49 abandoned in 1984.

Dissolved Iron Concentrations in Water from Production We11s

Water from the production wells is drawn from all parts of the aquifer because of the near homogeneous properties. Thus, iron-rich water from the upper part of the aquifer mixes with iron-poor water from the lower part of the aquifer. Mixing occurs as water from the upper and lower parts of the aquifer is drawn to the well through screens placed in the lower part of the aquifer. A schematic diagram showing the production wells and $\mathrm{pH}$, and dissolved iron concentration is shown in figure 14. When part of the flow in the aquifer is discharged to pumping wells, the flow direction changes in 


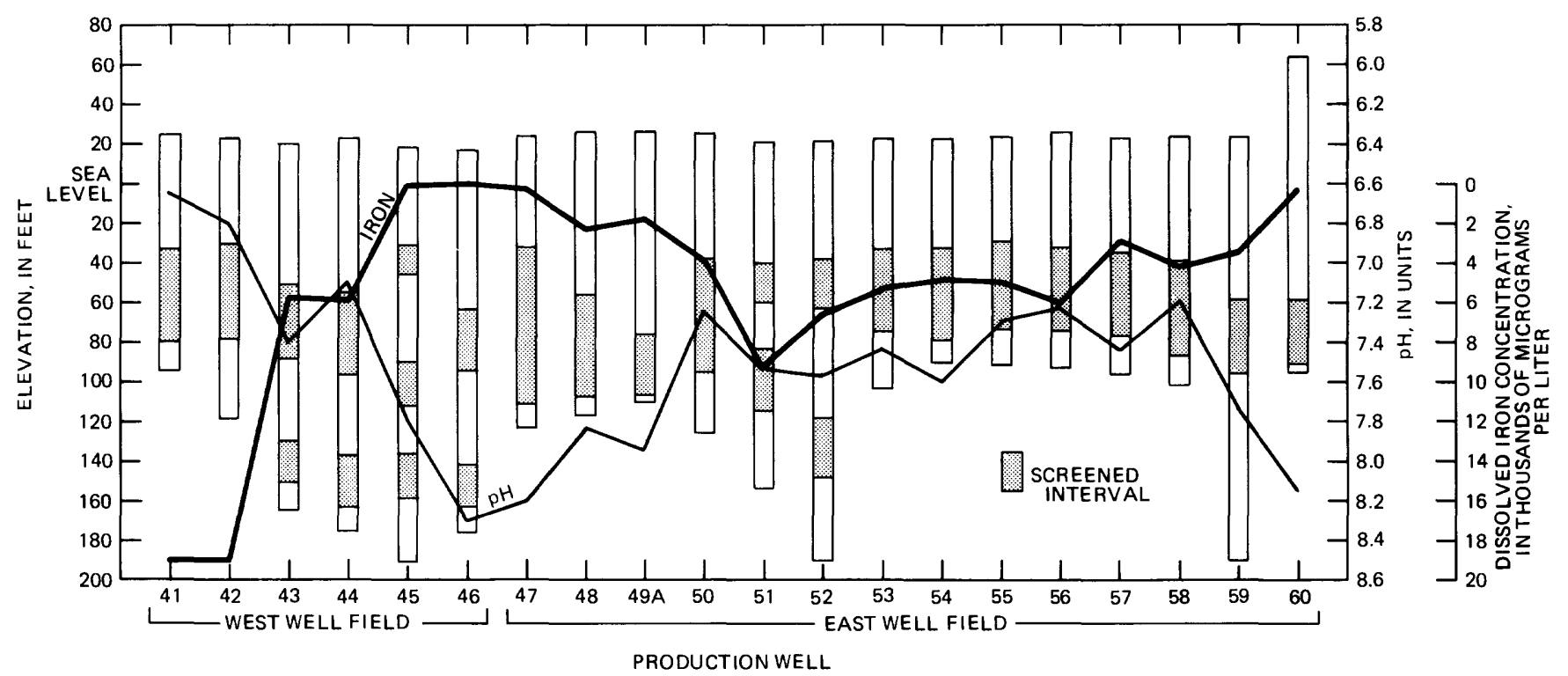

Figure 14.--Dissolved iron concentration and pH in water from the dune-sand production wells, July 1988.

response to head changes. Changes in flow direction induce vertical mixing in the region of a pumping well. Mixing of water under pumping and natural conditions in an unconfined aquifer is shown conceptually in figure 15.

Vertical exchange of water in the region of a pumping well is consistent with interpretations of $\mathrm{pH}$ values and iron concentrations in water from production wells. Values of $\mathrm{pH}$ are lower and iron concentrations are larger in water from most of the production wells compared to water from deep piezometers. With the exception of the shallowest piezometer (SCP5C) in the deep part of the aquifer, $\mathrm{pH}$ values observed in the deep aquifer in the southern part of the dunes range from 7.7 to 8.5 , and iron concentrations range from 7 to $690 \mu \mathrm{g} / \mathrm{L}$ (see table 6). In contrast, $\mathrm{pH}$ values of water from production wells located in the southern part of the dunes range from 6.6 to 8.3 , and dissolved iron concentrations range from 30 to $19,000 \mu \mathrm{g} / \mathrm{L}$ (table 10). The median iron concentration is $3,600 \mu \mathrm{g} / \mathrm{L}$; the median $\mathrm{pH}$ is 7.4 . The lower $\mathrm{pH}$ values and larger iron concentrations observed in water from production wells compared with water from deep piezometers indicate a mixing of upper and lower aquifer water. As shown in figure 16, there is a good correlation between $\mathrm{pH}$ and dissolved iron concentration from water in the production wells. This trend is indicative of the resultant mixture of water from the upper and lower part of the aquifer.

Although water from the production wells represents a mixture of shallow and deep water, a question arises as to whether iron concentrations are lowered significantly as shallow water is forced to move to the deeper aquifer containing shell fragments. As shown in table 11, all but two production wells, W60 and W44, have their screens directly exposed to shell fragment layers. Given the abundance of shell fragments in the southern part of the dunes, the deep water moving to well W44 probably passes through shell fragments upgradient of the well in the deep flow path, and in view of the high $\mathrm{pH}$ values, deep water in the northernmost wel1 W60 probably passes through shell fragments upgradient of the well. 


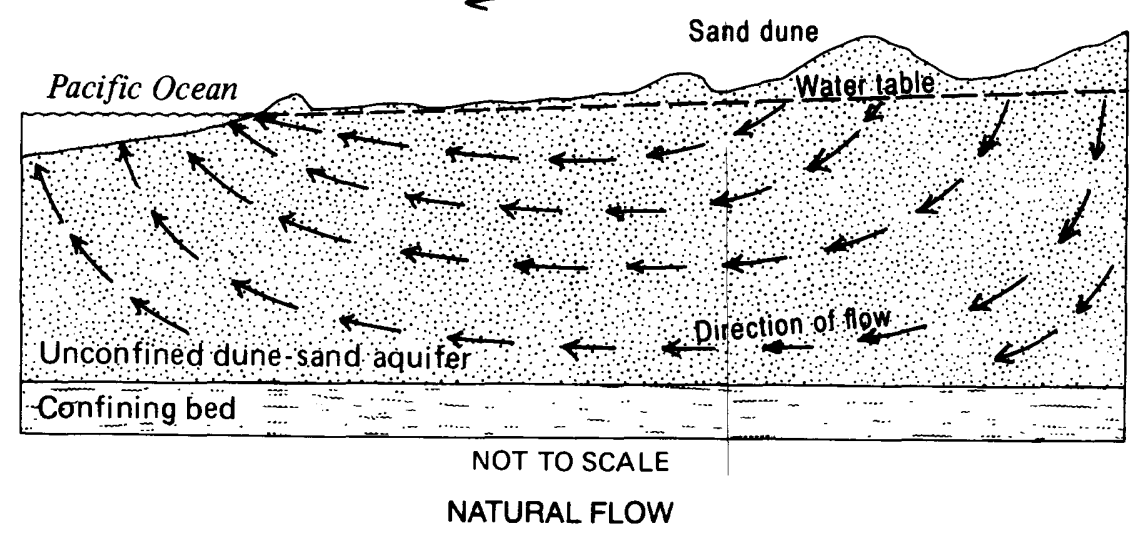

Recharge area $\longrightarrow$

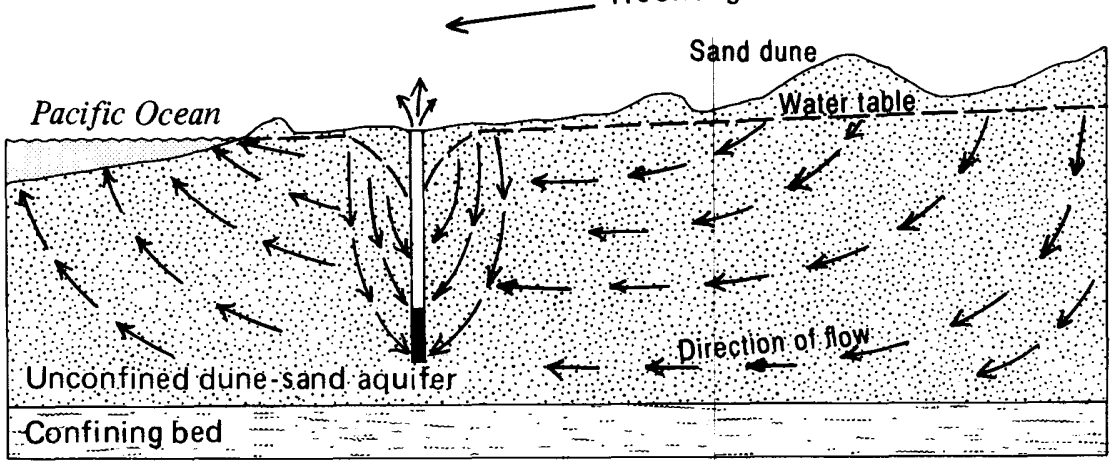

NOT TO SCALE

CHANGE IN NATURAL FLOW DUE TO PUMPING

Figure 15.--Conceptual changes in ground-water flow patterns in an unconfined aquifer due to pumping (adapted from Heath, 1987, p. 33).

Table 10, - Chemical data and saturation indices for ground water from production wells

[See plate 1 for location of wells; the saturation index, SI, is the logarithm of the quotient of the ion-activity product divided by the equilibrium constant, a positive SI indicates supersaturation and a negative SI undersaturation with respect to the mineral; dashes indicate no data; n.d. = dissolved ferrous iron not detected in solution; 10 micrograms per liter used in SI calculation.]

\begin{tabular}{|c|c|c|c|c|c|c|c|c|c|c|c|c|c|c|c|c|c|}
\hline \multirow[b]{2}{*}{ Well } & \multirow[b]{2}{*}{ Date } & \multirow{2}{*}{$\begin{array}{l}\text { Specific } \\
\text { conduc- } \\
\text { tance } \\
\text { (micro- } \\
\text { siemens } \\
\text { at } 25^{\circ} \mathrm{C} \text { ) }\end{array}$} & \multirow[b]{2}{*}{$\underset{\text { (units) }}{\text { pH }}$} & \multirow{2}{*}{$\begin{array}{l}\text { Temper- } \\
\text { ature } \\
\left({ }^{\circ} \mathrm{c}\right)\end{array}$} & \multirow{2}{*}{$\begin{array}{l}\text { Dis. } \\
\text { solved } \\
\text { oxygen } \\
\text { (....... }\end{array}$} & \multirow{2}{*}{$\begin{array}{l}\text { Dis- } \\
\text { solved } \\
\text { cal- } \\
\text { cium }\end{array}$} & \multirow{2}{*}{$\begin{array}{l}\text { Dis- } \\
\text { solved } \\
\text { magne- } \\
\text { sium }\end{array}$} & \multirow{2}{*}{$\begin{array}{l}\text { Dis. } \\
\text { solved } \\
\text { sodium } \\
\text { - millig }\end{array}$} & \multirow{2}{*}{$\begin{array}{l}\text { Dis- } \\
\text { solved } \\
\text { potas- } \\
\text { sium } \\
\text { rams per }\end{array}$} & \multirow{2}{*}{$\begin{array}{l}\text { Bicar. } \\
\text { bonate } \\
\text { liter. }\end{array}$} & \multirow{2}{*}{$\begin{array}{l}\text { Dis. } \\
\text { solved } \\
\text { sulfate }\end{array}$} & \multirow{2}{*}{$\begin{array}{l}\text { Chlor- } \\
\text { ide }\end{array}$} & \multirow{2}{*}{$\begin{array}{l}\text { Dis. } \\
\text { solved } \\
\text { silica } \\
\text { as } \mathrm{SiO}_{2} \\
\cdots\end{array}$} & \multicolumn{2}{|c|}{ Dissolved iron } & \multicolumn{2}{|c|}{ SI } \\
\hline & & & & & & & & & & & & & & $\begin{array}{l}\text { ferrous } \\
\text { (microgra } \\
\text { per lite }\end{array}$ & $\begin{array}{l}\text { ams } \\
\text { er) }\end{array}$ & $\begin{array}{l}\text { Sider- } \\
\text { ite }\end{array}$ & $\begin{array}{l}\text { Cal- } \\
\text { cite }\end{array}$ \\
\hline $\begin{array}{l}W 41 \\
W 42 \\
W 43 \\
W 44^{a} \\
W 45\end{array}$ & $\begin{array}{l}7 / 25 / 88 \\
7 / 21088 \\
7 / 21 / 88 \\
3 / 20 / 82 \\
7 / 21 / 88\end{array}$ & $\begin{array}{l}278 \\
265 \\
329 \\
268 \\
280\end{array}$ & $\begin{array}{l}6.6 \\
6.8 \\
7.4 \\
7.1 \\
7.8\end{array}$ & $\begin{array}{l}14.5 \\
13.3 \\
12.9 \\
13.4 \\
14.3\end{array}$ & $\begin{array}{l}\ddot{0.0} \\
0.0 \\
\ddot{0} .0\end{array}$ & $\begin{array}{l}24 \\
17 \\
33 \\
23 \\
19\end{array}$ & $\begin{array}{l}7.2 \\
5.3 \\
10 \\
11 \\
14\end{array}$ & $\begin{array}{l}19 \\
17 \\
14 \\
14 \\
16\end{array}$ & $\begin{array}{l}3.5 \\
3.7 \\
7.0 \\
7.9 \\
5.4\end{array}$ & $\begin{array}{l}131 \\
129 \\
182 \\
163 \\
142\end{array}$ & $\begin{array}{c}12 \\
29 \\
7.9 \\
11 \\
3.5\end{array}$ & $\begin{array}{l}20 \\
20 \\
16 \\
22 \\
20\end{array}$ & $\begin{array}{l}33 \\
28 \\
30 \\
29 \\
25\end{array}$ & $\begin{array}{r}19,000 \\
19,000 \\
5,800 \\
\ldots \\
110\end{array}$ & 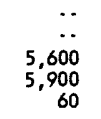 & $\begin{array}{r}+0.33 \\
+.45 \\
+.63 \\
+.34 \\
+.97\end{array}$ & $\begin{array}{r}-1.41 \\
-1.44 \\
-.42 \\
-.91 \\
-. .31\end{array}$ \\
\hline $\begin{array}{l}\text { W46 } \\
W 47 \\
W 48 \\
W 49 A \\
W 50\end{array}$ & $\begin{array}{l}7 / 21 / 88 \\
7 / 22 / 88 \\
7 / 22 / 88 \\
7 / 22 / 88 \\
7 / 22 / 88\end{array}$ & $\begin{array}{l}323 \\
306 \\
260 \\
236 \\
293\end{array}$ & $\begin{array}{l}8.3 \\
8.2 \\
7.8 \\
7.9 \\
7.2\end{array}$ & $\begin{array}{l}13.3 \\
14.5 \\
15.2 \\
15.4 \\
14.8\end{array}$ & $\begin{array}{l}0.0 \\
0.0 \\
0.0 \\
0.0 \\
0.0\end{array}$ & $\begin{array}{l}25 \\
35 \\
31 \\
36 \\
36\end{array}$ & $\begin{array}{l}16 \\
7.8 \\
5.4 \\
3.9 \\
6.0\end{array}$ & $\begin{array}{l}19 \\
15 \\
12 \\
10 \\
14\end{array}$ & $\begin{array}{l}5.0 \\
6.7 \\
4.7 \\
3.5 \\
4.8\end{array}$ & $\begin{array}{l}160 \\
166 \\
137 \\
129 \\
168\end{array}$ & $\begin{array}{l}4.3 \\
1.9 \\
2.2 \\
3.1 \\
5.0\end{array}$ & $\begin{array}{l}25 \\
17 \\
14 \\
12 \\
14\end{array}$ & $\begin{array}{l}25 \\
24 \\
22 \\
23 \\
29\end{array}$ & $\begin{array}{r}30 \\
200 \\
2,200 \\
1,800 \\
3,900\end{array}$ & $\begin{array}{r}\text { n.d. } \\
2 . \\
2,200 \\
1,600 \\
3,700\end{array}$ & $\begin{array}{r}-1.26 \\
-.013 \\
+.62 \\
+.56 \\
+.33\end{array}$ & $\begin{array}{r}+.30 \\
+.38 \\
-.083 \\
+.057 \\
-.54\end{array}$ \\
\hline $\begin{array}{l}\text { W51 } \\
W 52 \\
W 53 \\
\text { W54 } \\
\text { W55 }\end{array}$ & $\begin{array}{l}7 / 22 / 88 \\
7 / 22 / 88 \\
7 / 21 / 88 \\
7 / 21 / 88 \\
7 / 21 / 88\end{array}$ & $\begin{array}{l}345 \\
296 \\
305 \\
390 \\
285\end{array}$ & $\begin{array}{l}7.5 \\
7.6 \\
7.4 \\
7.6 \\
7.3\end{array}$ & $\begin{array}{l}14.7 \\
15.1 \\
14.6 \\
15.1 \\
15.4\end{array}$ & $\begin{array}{l}0.0 \\
0.0 \\
0.0 \\
0.0 \\
0.0\end{array}$ & $\begin{array}{l}43 \\
30 \\
36 \\
37 \\
24\end{array}$ & $\begin{array}{l}6.5 \\
7.4 \\
6.5 \\
9.8 \\
6.9\end{array}$ & $\begin{array}{l}13 \\
14 \\
15 \\
25 \\
20\end{array}$ & $\begin{array}{l}5.3 \\
6.6 \\
4.2 \\
5.6 \\
4.1\end{array}$ & $\begin{array}{r}199 \\
174 \\
167 \\
196 \\
-138\end{array}$ & $\begin{array}{l}6.6 \\
3.5 \\
4.6 \\
2.7 \\
5.2\end{array}$ & $\begin{array}{l}14 \\
13 \\
16 \\
29 \\
24\end{array}$ & $\begin{array}{l}33 \\
29 \\
28 \\
31 \\
29\end{array}$ & $\begin{array}{l}9,300 \\
6,600 \\
5,300 \\
4,800 \\
5,100\end{array}$ & $\begin{array}{r}8,400 \\
6,600 \\
5,200 \\
4,800 \\
\ldots\end{array}$ & $\begin{array}{r}+1.03 \\
+.92 \\
+.66 \\
+.88 \\
+.45\end{array}$ & $\begin{array}{l}-.11 \\
-.27 \\
-.35 \\
-.090 \\
-.74\end{array}$ \\
\hline $\begin{array}{l}W 56 \\
W 57 \\
W 58 \\
W 59 \\
W 60 \\
\end{array}$ & $\begin{array}{l}7 / 21 / 88 \\
7 / 22 / 88 \\
7 / 25 / 88 \\
7 / 21 / 88 \\
7 / 21 / 88 \\
\end{array}$ & $\begin{array}{l}305 \\
330 \\
285 \\
245 \\
317 \\
\end{array}$ & $\begin{array}{l}7.2 \\
7.4 \\
7.2 \\
7.7 \\
8.2 \\
\end{array}$ & $\begin{array}{l}14.5 \\
14.5 \\
14.5 \\
14.1 \\
14.5 \\
\end{array}$ & $\begin{array}{l}0.0 \\
\ldots \\
0.0 \\
0.0\end{array}$ & $\begin{array}{l}28 \\
35 \\
30 \\
27 \\
23 \\
\end{array}$ & $\begin{array}{l}8.9 \\
6.8 \\
4.9 \\
4.5 \\
6.8 \\
\end{array}$ & $\begin{array}{l}19 \\
20 \\
20 \\
15 \\
30 \\
\end{array}$ & $\begin{array}{l}4.7 \\
4.4 \\
3.3 \\
2.9 \\
5.8 \\
\end{array}$ & $\begin{array}{l}154 \\
155 \\
128 \\
121 \\
159 \\
\end{array}$ & $\begin{array}{c}10 \\
1.7 \\
2.2 \\
7.9 \\
1.5 \\
\end{array}$ & $\begin{array}{l}23 \\
24 \\
23 \\
16 \\
24 \\
\end{array}$ & $\begin{array}{l}29 \\
35 \\
29 \\
27 \\
30 \\
\end{array}$ & $\begin{array}{r}6,000 \\
3,000 \\
\ldots \\
3,500 \\
370 \\
\end{array}$ & $\begin{array}{r}6,000 \\
3,000 \\
4,200 \\
3,400 \\
330 \\
\end{array}$ & $\begin{array}{l}+.48 \\
+.38 \\
+.22 \\
+.63 \\
+.15 \\
\end{array}$ & $\begin{array}{r}-.70 \\
-.40 \\
-.77 \\
-.31 \\
+.15 \\
\end{array}$ \\
\hline
\end{tabular}

$a_{W 44}$ not operational at time of sampling; complete chemical analysis available 3/20/82 (Dobberpuhl, 1985 ). 
Table 11.--Production wells and Percentage of wel1 screen exposed to shell fragment layers

\begin{tabular}{lc}
\hline & $\begin{array}{c}\text { Percentage of } \\
\text { screen exposed } \\
\text { to she11 fragme }\end{array}$ \\
We11 & 16 \\
W41 & 18 \\
W42 & 14 \\
W43 & 0 \\
W44 & 16 \\
W45 & \\
W46 & 88 \\
W47 & 71 \\
W48 & 67 \\
W49 & 45 \\
W50 & 12 \\
W51 & \\
W52 & 50 \\
W53 & 54 \\
W54 & 64 \\
W55 & 97 \\
W56 & 37 \\
W57 & \\
W58 & \\
W59 & 41 \\
W60 & 79 \\
& 78 \\
\end{tabular}

To decrease dissolved iron concentrations, shallow water moving to the deep part of the aquifer must have sufficient residence time to dissolve calcite and precipitate siderite. Water from 16 of the 20 production wells is undersaturated with respect to calcite, and the dissolved iron concentrations in these waters range widely from 30 to $19,000 \mu \mathrm{g} / \mathrm{L}$ (table 10). Most water from the production wells is supersaturated with respect to siderite, and iron removal by siderite precipitation is thermodynamically possible. However, much of the iron dissolved in the shallow water that is forced to move to the deeper aquifer apparently is not removed by siderite precipitation. Only water from W45, W46, W47, and W60 is low in dissolved iron (30-370 $\mu \mathrm{g} / \mathrm{L})$.

Chemical equilibrium is not likely to be achieved if the residence time of the water is shorter than the time required for chemical reactions to approach completion. The inefficiency of iron removal by siderite precipitation in the region of a pumping well is consistent with the relatively slow precipitation of carbonates in natural systems (Morgan, 1967, p. 12) compared with transit time of water moving from the top to the bottom of the aquifer in the region of a pumping well. The time required for precipitation of carbonates to occur in natural aqueous systems may be relatively long compared with the transit time of 1 to 2 days that was calculated for water to move about 140 feet from the top of the aquifer to the lower screen at production well W44 (J. E. Luzier, U.S. Geological Survey, written commun., 1982). 


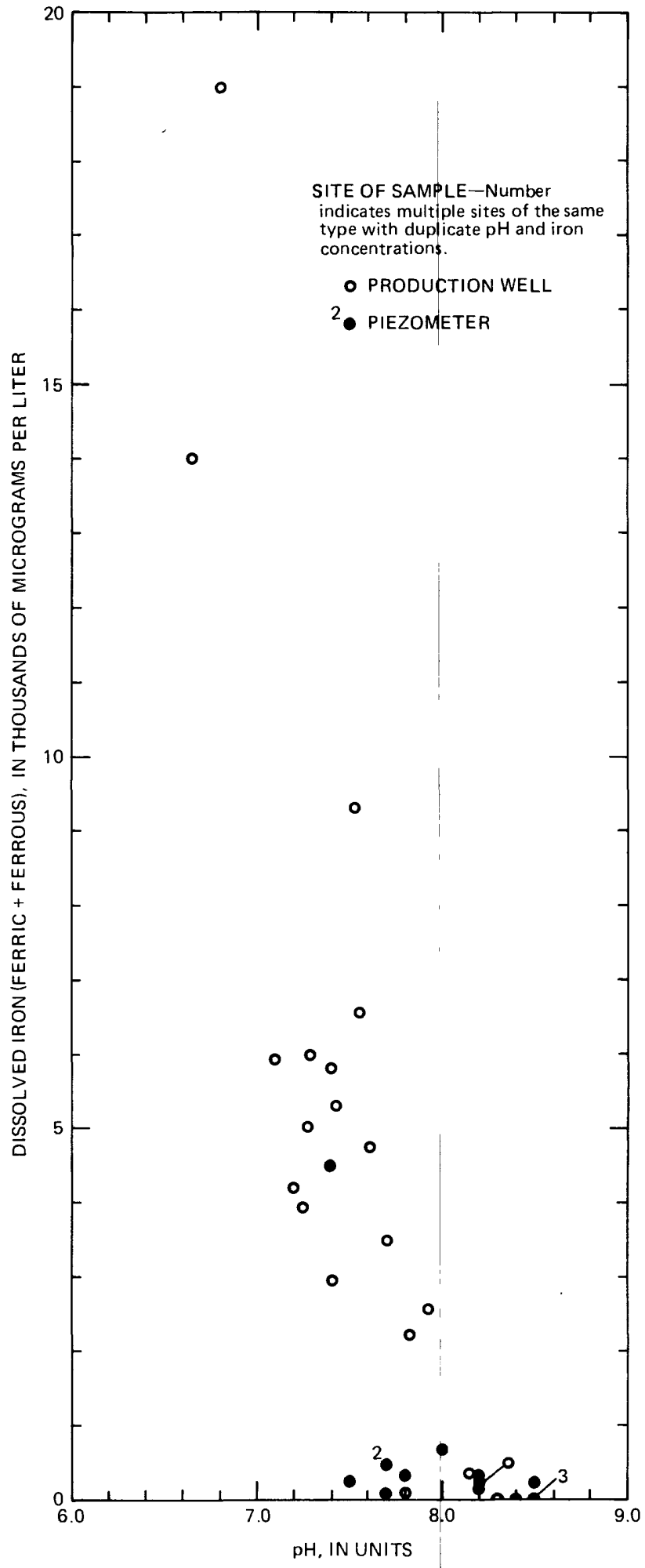

Figure 16.--Relation between dissolved iron concentration and $\mathrm{pH}$ in water from the production wells and piezometers from the southern part of the dunes. 


\section{Long-Term Changes in Dissolved Iron Concentrations}

Pumping has occurred in the dune aquifer for about 20 to 25 years for most wells in operation. Time-trend analysis of iron concentrations indicates that a significant increase in iron concentration has occurred for 12 of the 20 wells (table 12). Examples of two wells (W41 and W55) which indicated a highly significant upward trend in iron concentration are shown in figure 17. Iron concentrations are plotted as maximum, minimum, and average values in figure 17, but time-trend analysis (table 12) was done using iron concentration determined monthly for each year.

The trend analysis given in table 12 is a Seasonal Kendall test described by Hirsch and others (1982), and Smith and others (1982). Trends are considered statistically significant for $p<0.10$. The symbol " $p$ " is the probability that an apparent trend results from a chance arrangement of the data rather than an actual change in concentration.

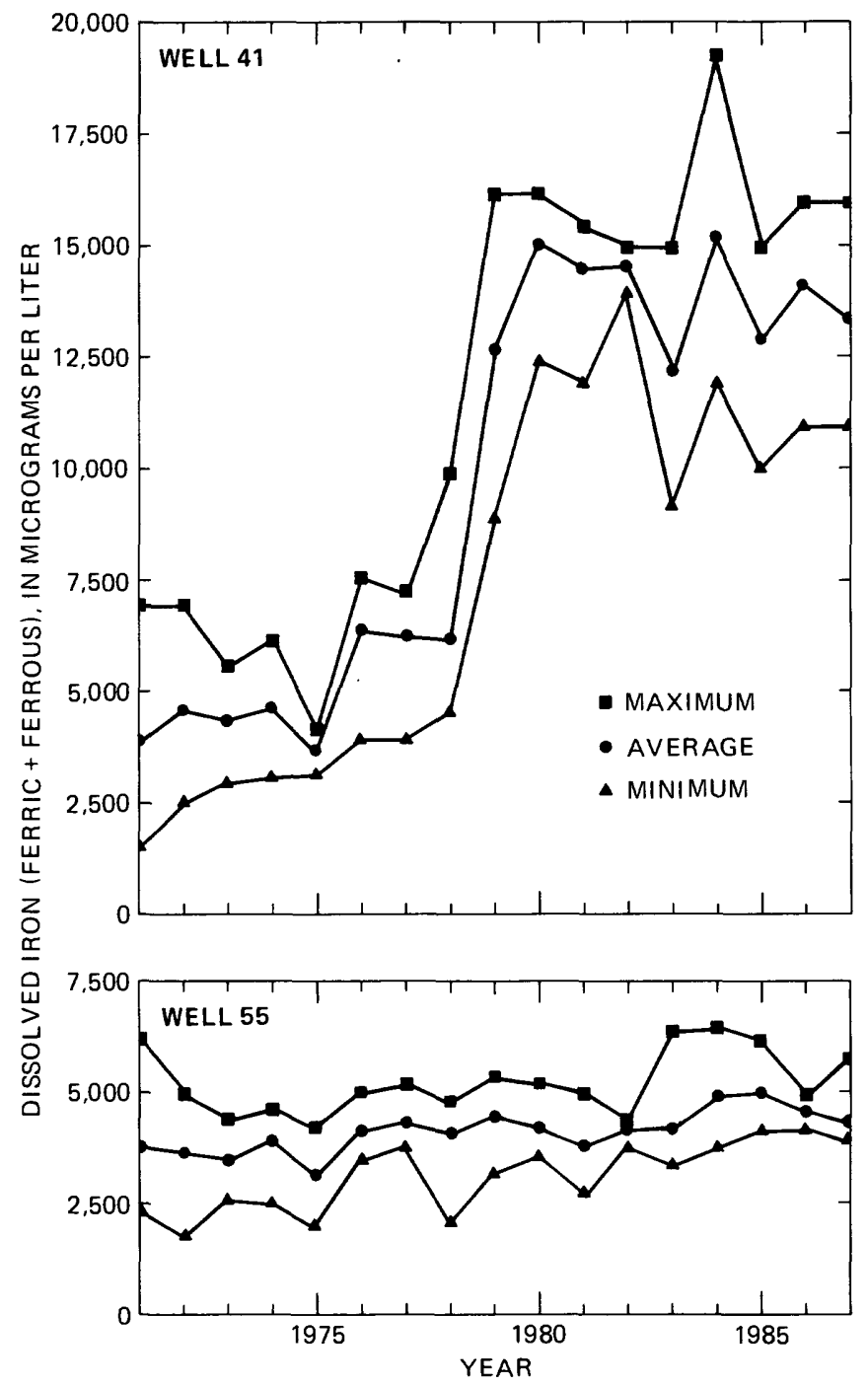

Figure 17.--Time trend of dissolved iron concentration in water from production wells 41 and 55 . 
Table 12.--Occurrence of trends for dissolved iron concentrations in production wells using Seasonal Kendall test

[UT = upwards trend, DT = downwards trend, and $\mathrm{NT}=$ no trend; trends were considered statistically significant for probability value $<0.10$. Those trends that are statistically significant at the 10-percent level are marked with an "S" and those at the 1-percent level by an "HS" corresponding to significant and highly significant, respectively]

\begin{tabular}{|c|c|c|}
\hline We11 & $\begin{array}{c}\text { Dissolved } \\
\text { iron } \\
\text { concentration }\end{array}$ & $\begin{array}{l}\text { Period of record } \\
\text { (monthly data) }\end{array}$ \\
\hline W41 & UT (HS) & $1971-87$ \\
\hline W42 & UT (HS) & Do. \\
\hline W43 & UT (S) & Do. \\
\hline W44 & UT (HS) & Do. \\
\hline W45 & $\mathrm{NT}$ & Do. \\
\hline W46 & $\mathrm{NT}$ & Do. \\
\hline W47 & UT (HS) & $1958-87$ \\
\hline W48 & $\mathrm{NT}$ & Do. \\
\hline W49 & $\mathrm{NT}$ & $1958-85$ \\
\hline W50 & $\mathrm{DT}(\mathrm{S})$ & $1971-87$ \\
\hline W51 & UT (HS) & Do. \\
\hline W52 & UT (HS) & Do. \\
\hline W53 & $\mathrm{NT}$ & Do. \\
\hline W54 & $\mathrm{NT}$ & Do. \\
\hline W55 & UT (HS) & Do. \\
\hline W56 & UT (HS) & Do. \\
\hline W57 & UT (HS) & Do. \\
\hline W58 & UT (HS) & Do. \\
\hline W59 & $\mathrm{UT}(\mathrm{S})$ & $1980-87$ \\
\hline W60 & NT & Do. \\
\hline
\end{tabular}

Two processes believed to explain the long-term increase in iron concentration are:

(1) The progressive encroachment of lodgepole pine and other vegetation on the dune surface causes an increasing volume of the aquifer to become iron rich.

(2) The aquifer sediments are losing their neutralization capacity as ferrous iron in solution combines with carbonate ion that is dissolved from marine shell fragments; thus, long-term changes have occurred in dynamics of mixing iron-rich water from the upper part of the aquifer with ironpoor water in the lower part of the aquifer. 
The first process likely occurs because it can be shown conclusively from aerial photographs that lodgepole pine and other vegetation have progressively encroached the dune surface (Bortleson and others, 1989). The proliferation of young lodgepole pine trees growing in many areas of the dunes is readily apparent by visual observations. Thus, the historical plant-induced changes probably are responsible for the increase in iron concentration.

In the second process, although an increasing flux of ferrous iron combines with carbonate to form siderite, the loss in neutralization capacity is not readily apparent. In water from deep piezometers some distance from pumping wells, iron concentrations have remained the same over a long period of time. For example, P45 was sampled in 1971, 1979, and 1986, and iron concentrations were 410,440 , and $460 \mu \mathrm{g} / \mathrm{L}$, respectively. These data suggest that the dynamics of natural system have not changed significantly and the neutralization capacity of the aquifer has remained the same.

\section{CONCEPTUAL MODEL OF GEOCHEMICAL PROCESSES}

A conceptual model to describe geochemical processes controlling iron concentrations in the dune aquifer was developed from results of this study. A diagram of this model is shown in figure 18. Precipitation and sea-salt aerosols falling on the dunes is a dilute sodium-chloride type water. This water infiltrates dune sands that contain iron-bearing minerals that include iron titanium oxides, pyroxene, pyrite, and amorphous iron oxides. Amorphous iron may derive from the alteration of grain surfaces, or fine-grained material deposited with the sands. Most iron is present in the fraction less than 40 micrometers. The fine-sand fraction is 10 times more enriched in iron than bulk sand.

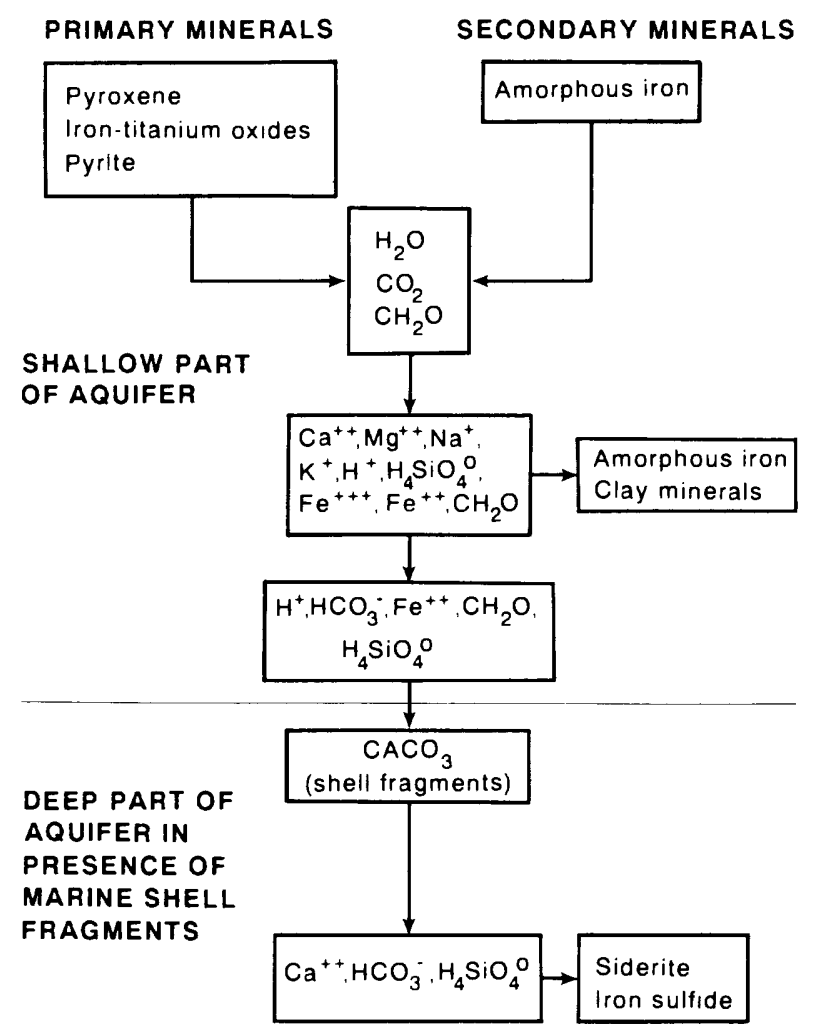

Figure 18.--Conceptual geochemical model of the dune-sand aquifer. 
Large concentrations of dissolved organic compounds and carbon dioxide released by organic decay and respiration in the root zone leach to shallow ground water from areas of forest and increase the capacity of shallow water to dissolve iron-bearing minerals. Dissolved oxygen concentrations are usually $0.0 \mathrm{mg} / \mathrm{L}$ in forested areas and commonly in bare sand areas. However, concentrations of dissolved oxygen as large as $4.7 \mathrm{mg} / \mathrm{L}$ were observed in bare sand areas. The $\mathrm{pH}$ of shallow ground water differs only slightly in forested compared with bare sand areas. Acid hydrolysis of iron-bearing minerals is accompanied by oxidation of organic carbon that generates bicarbonate. Thus, water that had infiltrated forested areas is enriched in dissolved iron and bicarbonate (fig. 18). Resultant $\mathrm{pH}$ values range from 5.6 to 6.7 , and concentrations of dissolved iron commonly exceed 5,000 $\mu \mathrm{g} / \mathrm{L}$.

Although lodgepole pine forest is the predominant vegetation, other vegetation affects dissolved iron concentrations in the shallow aquifer. Shallow water that had infiltrated areas of herbacious vegetation of European beach grass and sedge is smaller in dissolved iron concentration compared with water that had infiltrated areas of woody shrub and forest. These data strongly indicate a correlation between the amount of dissolved iron in shallow ground water and the biomass of the plant community.

Dissolved iron concentrations in water from parts of the deeper aquifer are small. This water is prevented from attaining large iron concentrations by the presence of marine shell fragments. The dissolution of calcium carbonate in shell fragments raises the $\mathrm{pH}$ (near or above $\mathrm{pH} 8.0$ ) and carbonate-bicarbonate concentration, causing iron to precipitate as siderite. Water infiltrating deep sands containing shell fragments is enriched in calcium and bicarbonate ions (fig. 18).

Water pumped from the production wells is a mixture of small concentrations of iron from the lower part of the aquifer and large concentrations of iron from the upper part of the aquifer. The median iron concentration is $4,500 \mu \mathrm{g} / \mathrm{L}$, and the median $\mathrm{pH}$ is 7.4. Mixing of water is indicated by lower $\mathrm{pH}$ values and larger dissolved iron concentrations in the water from most of the production wells compared to water taken from deep piezometers that draw only deep water. Shallow water that is forced by pumping to move to the deeper aquifer and infiltrate marine shell fragments does not significantly react with calcite to raise $\mathrm{pH}$ and carbonatebicarbonate concentrations in water of most production we11s. For most water in the region of pumping wells, the hydraulic residence time is apparently less than the time required to dissolve calcite or precipitate siderite. This is consistent with the observation that most water from production wells was undersaturated with respect to calcite.

\section{SUMMARY AND CONCLUSIONS}

The amount of iron dissolved in ground water is a function of chemical reactions between ground water and iron-bearing minerals in the sand, and by patterns of ground-water movement. Large concentrations of dissolved organic compounds and carbon dioxide leach from areas covered by lodgepole pine forest to the shallow ground water and increase the capacity of shallow ground water to dissolve iron-bearing minerals. 
Dissolved iron concentrations were largest in shallow ground water that had infiltrated areas of lodgepole pine forest and smallest in water that had infiltrated bare sand. Forest cover makes up about 50 percent of the dune surface; shallow water beneath forest cover commonly has 2,500 to $30,000 \mu \mathrm{g} / \mathrm{L}$ of dissolved iron. Woody shrub and forest cover cause more iron to be released to shallow ground water than herbacious plant cover.

Dissolved iron concentrations in water from most deeper parts of the aquifer are small. The dissolution of calcium carbonate in shell fragments raises the $\mathrm{pH}$ and carbonate-bicarbonate concentration of water to remove dissolved iron by precipitation as siderite (ferrous carbonate). Values of $\mathrm{pH}$ observed in parts of the aquifer containing shell fragments are near or above $\mathrm{pH} 8.0$, and iron concentrations are only a few tens or hundreds of micrograms per liter. In parts of the deep aquifer that lack shell material to buffer iron concentrations by siderite precipitation, iron concentrations increase with depth. However, the iron concentration may not be a function solely of depth or residence time.

Twenty production wells are located in the southern part of the dunes where lodgepole pine forest grows over much of the dunes and where marine shell fragments are abundant in the lower part of the aquifer. Water pumped from the production wells is a mixture of water from the lower part of the aquifer and water from the upper part of the aquifer. The median iron concentration is $4,500 \mu \mathrm{g} / \mathrm{L}$, and the median $\mathrm{pH}$ is 7.4. Mixing of shallow water with deep is indicated by generally lower $\mathrm{pH}$ values and larger iron concentrations in the water from most of the production wells compared with water pumped from deep piezometers that draw only the deep water.

Time-trend analysis of water from production wells indicates that a significant increase in iron has occurred for 12 of the 20 wells currently in operation. It is the authors' opinion that the long-term increase in iron concentration is due to the progressive invasion of lodgepole pine and other vegetation on the sand dune surface. This increased forestation causes an increasing volume of the aquifer to become iron rich.

The quality of production water would be enhanced if new production wells in the dune-sand aquifer were to be located where dissolved iron concentrations in both the shallow and deep part of the aquifer are within tolerable limits for municipal and industrial water supply. The upper part of the aquifer in the northern part of the dunes has generally smaller iron concentrations than in the southern part of the dunes because of less forestation. Throughout the dunes, water that has infiltrated sands containing shell fragments has smaller iron concentrations than any of the other areas. In the southern part of the dunes, small dissolved iron concentrations are usually found at elevations below -85 feet, and in the northern part of the dunes small iron concentrations are commonly found near the base of the sand aquifer. Iron enrichment of the upper part of the aquifer is evidenced by the general increase in iron concentrations from pumped waters in the 20- to 25-year operational history. Long-range management of lodgepole pine forest may be required to avoid continued iron enrichment of the upper aquifer. 
Baldwin, E.M., 1964, Geology of Oregon: Edward Brothers, Inc., Ann Arbor, Michigan, $140 \mathrm{p}$.

Bennett, P.C., Melcer, M.E., Siegel, D.I., Hassett, J.P., 1988, The dissolution of quartz in dilute aqueous solutions of organic acids at $25^{\circ} \mathrm{C}$ : Geochimica et Cosmochimica Acta, v. 52, p. 1521-1530.

Berner, R.A., and Schott, Jacques, 1982, Mechanism of pyroxene and amphibole weathering II. Observations of soil grains: American Journal of Science, v. 282 , p. 1214-1231.

Bortleson, G.C., Jones, M.A., and Hearn, P.P., 1989, Geochemistry of iron in a sand dune aquifer near Coos Bay and North Bend, Oregon: U.S. Geological Survey Open-File Report 88-734, $37 \mathrm{p}$.

Brown, S.G., and Newcomb, R.C., 1963, Ground-water resources of the sand-dune area north of Coos Bay, Oregon: U.S. Geological Survey Water-Supply Paper $1619-\mathrm{D}, 32 \mathrm{p}$.

Christensen, Ralph, and Rosenthal, Gerald, 1982, North Florence dune aquifer study: Final report for Lane County and Lane County Council of Governments, $153 \mathrm{p}$.

Dobberpuhl, R.A., Luzier, J.E., and Collins, C.A., 1985, Selected waterquality data for a coastal dunes aquifer near Coos Bay, Oregon - 1971 to 1983: U.S. Geological Survey Open-File Report 84-858, 192 p.

Frank, F.J., 1970, Ground-water resources of the Clatsop Plains sand-dune area, Clatsop County, Oregon: U.S. Geological Survey Water-Supply Paper $1899-\mathrm{A}, 36 \mathrm{p}$.

Hampton, E.R., 1963, Ground water in the coastal dune area near Florence, Oregon: U.S. Geological Survey Water-Supply Paper 1539-K, 36 p.

Heath, R.C., 1987, Basic ground-water hydrology: U.S. Geological Survey Water-Supply Paper 2220, 84 p.

Hem, J.D., 1967, Equilibrium chemistry of iron in ground water, in Faust, S.D., and Hunter, J.V., eds., Principles and applications of water chemistry: New York, John Wiley and Sons, p. 625-643.

- - -1985, Study and interpretation of chemical characteristics of natural water: U.S. Geological Survey Water-Supply Paper 2254, 263 p.

Hirsch, R.M., Slack, J.R., and Smith, R.A., 1982, Techniques of trend analysis for monthly water quality data: Water Resources Research, v. 18, p. $107-121$.

Huang, W.H., and Keller, W.D., 1970, Dissolution of rock forming silicate minerals in organic acids: Simulates first stage weathering of fresh mineral surfaces: American Mineralogy, v, 55, p. 2076-2094. 
Jaurequi, M.A., and Reisenauer, H.M., 1982, Dissolution of oxides of manganese and iron by root exudate components: Journal of American Society of Soil Science, v. 46, p. 314-317.

Klein, C., and Hurlbut, C., Jr., 1985, Manual of mineralogy: New York, John Wiley and Sons, $332 \mathrm{p}$.

Lovley, D.R., Stolz, J.F., Nord, G.L., Jr., and Phillips, E.S.P., 1987, Anaerobic production of magnetite by a dissimilatory iron-reducing microorganism: Nature, v. 330 , no. 6145, p. 252-254.

Magaritz, Mordeckai, and Luzier, J.E., 1985, Water-rock interaction and seawater-freshwater mixing effects in the coastal dunes aquifer, Coos Bay, Oregon: Geochimica et Cosmochemica Acta, v. 49, p. 2515-2525.

McKeague, J.A., and Day, J.H., 1967, Dithionate and oxalate extractable Fe and Al as aids in differentiating various classes of soils: Canadian Journal of Soil Science, v. 46, p. 13-22.

Morgan, J.J., 1967, Applications and limitations of chemical thermodynamics in natural water systems: in Equilibrium concepts in natural water systems, Advances in Chemistry series 67: American Chemical Society, p. 1-29.

Neal, C., Smith, C.J., We11s, J., and Dunn, C.S., 1986, Major, minor and trace element mobility in the acidic upland forested catchment of the upper River Severn, Mid.Wales: Journal of the Geological Society, London, v. 143 , p. 635-648.

Nordstrom, D.K., and Munoz, J.L., 1986, Geochemica1 thermodynamics: The Benjamin/Cummings Publishing Co. Inc., Menlo Park, California, 447 p.

Plummer, L.N., Jones, B.F., and Truesde11, A.H., 1984, WATEQF - A FORTRAN IV version of WATEQ, a computer program for calculating chemical equilibrium of natural waters: U.S. Geological Survey Water-Resources Investigations 76-13 (revised), $70 \mathrm{p}$.

Reid, R.K., Reid, C.P.P., Powe11, P.E., and Szaniszlo, P.J., 1984, Comparison of siderophore concentrations in aqueous extracts of rhizosphere and . adjacent bulk soils: Pedobiologia, v. 26, p. 263-266.

Rightmire, C.T., and Hanshaw, B.B., 1973, Relationship between the carbon isotope composition of soil $\mathrm{CO}_{2}$ and dissolved carbonate species in ground water: U.S. Geological Survey Water-Resources Research, v. 9, no. 4, p. 958-967.

Robison, J.H., 1973, Hydrology of the dunes area north of Coos Bay, Oregon: U.S. Geological Survey Open-File Report, 62 p.

Sapik, D.B., 1988, Documentation of a steady-state saltwater-intrusion model for three-dimensional ground-water flow, and user's guide: U.S. Geological Survey Open-File Report 87-526, 174 p.

Schott, Jacques, and Berner, R.A., 1983, X-ray photoelectron studies of the mechanism of iron silicate dissolution during weathering: Geochimica et Cosmochimica Acta, v. 47, p. 2233-2240. 
Skougstad, M.W., Fishman, M.J., Friedman, L.C., Erdmann, D.E., and Duncan, S.S., eds., 1979, Methods for determination of inorganic substances in water and fluvial sediments: U.S. Geological Survey Techniques of WaterResources Investigations, Book 5, Chapter 41, 626 p.

Smith, R.A., Hirsch, R.M., and Slack, J.R., 1982, A study of trends in total phosphorus measurements at NASQAN stations: U.S. Geological Survey Water-Supply Paper 2190, 33 p.

Stevenson, F.J., 1985, Geochemistry of soil humic substances, p. 3 - in Aiken, G.R., and others, eds., Humic substances in soil, sediment, and water: p. 619 .

Theis, T.L., and Singer, P.C., 1974, Complexation of iron(II) oxygenation: Environmental Science and Technology, v. 8, p. 569-573.

Thurman, E.M., 1985, Organic geochemistry of natural water: Boston, Massachusetts, Martinus Nijhoff/Dr W. Junk Publishers, 497 p.

Tipping, E., 1981, The adsorption of aquatic humic substances by iron oxides: Geochimica et Cosmochimica Acta, v. 45, p. 191-199.

Trescott, P.C., 1975, Documentation of a finite-difference model for simulation of three dimensional ground-water flow: U.S. Geological Survey Open-File Report 75-438, 103 p.

U.S. Forest Service, 1972, Resource inventory report for the Oregon Dunes National Recreation Area Siuslaw National Forest: Pacific Northwest Region, 294 p.

Walte, D.T., and Morel, F.M.M., 1984, Photoreductive dissolution of colloidal iron oxides in natural water: Environmental Science and Technology, v. 18 , p. $860-868$.

Waring, R.H., and Schlesinger, W.H., 1985, Forest ecosystems concepts and management: New York, Academic Press, Inc., 340 p.

Welton, J.E., 1984, SEM petrology atlas: The American Association of Petroleum Geologists, p. 170-171.

Wiedemann, A.M., 1984, The ecology of Pacific Northwest coastal sand dunes, a community profile: Fish and Wildlife Service/OBS-84-04, $130 \mathrm{p}$.

Zinder, P.J., 1962, The pattern of influence of individual forest trees on soil properties: Ecology, v. 43, p. 130-133.

Zinder, Bettina, Furrer, Gerhard, and Stumm, Werner, 1986, The coordination chemistry of weathering: II. Dissolution of Fe(III) Oxides: Geochimica et Cosmochimica Acta, v. 50, p. 1861-1869. 
SUPPLEMENTAL DATA

Site Names for Piezometers

\begin{tabular}{|c|c|c|}
\hline This study & Other studies & Location \\
\hline BB1 & South Horsfall 1A, HF-1A & $24 \mathrm{~S} / 13 \mathrm{~W}-33 \mathrm{BAD} 01$ \\
\hline BB2 & South Horsfall $1, \mathrm{HF}-1 \mathrm{~B}$ & $24 \mathrm{~S} / 13 \mathrm{~W}-33 \mathrm{BAD} 02$ \\
\hline BB4 & BA-1B, East Bluebill 1A & $24 \mathrm{~S} / 13 \mathrm{~W}-33 \mathrm{CACO} 1$ \\
\hline BB7 & Lagoon 4 & $25 \mathrm{~S} / 13 \mathrm{~W}-05 \mathrm{BCC} 01$ \\
\hline BB8 & $\mathrm{BB}-1 \mathrm{~B}$ & $24 \mathrm{~S} / 13 \mathrm{~W}-32 \mathrm{ADDO} 1$ \\
\hline $\mathrm{HF} 2 \mathrm{H} 1$ & P44A & $24 \mathrm{~S} / 13 \mathrm{~W}-32 \mathrm{BAA0} 2$ \\
\hline $\mathrm{HF} 2 \mathrm{H} 2$ & P44 & $24 \mathrm{~S} / 13 \mathrm{~W}-32 \mathrm{BAA} 01$ \\
\hline P46Y & P46 & $24 \mathrm{~S} / 13 \mathrm{~W}-32 \mathrm{CCA} 01$ \\
\hline ss2 & Lagoon $1 \mathrm{~A}$ & $25 \mathrm{~S} / 13 \mathrm{~W}-06 \mathrm{DDA} 02$ \\
\hline ss3 & Lagoon 3 & $25 \mathrm{~S} / 13 \mathrm{~W}-06 \mathrm{DDB} 01$ \\
\hline TM4 & Tenmile lagoon 2, TM-2B & $23 \mathrm{~S} / 13 \mathrm{~W}-22 \mathrm{DACO} 2$ \\
\hline
\end{tabular}

\section{Stable Isotope Reporting Units}

Stable-isotope concentrations of carbon, oxygen, and hydrogen are expressed in delta units $(\delta)$ and are reported in parts per thousand. These units represent relative deviations in the heavy isotope fraction in water and are defined as

$$
\delta=\frac{\mathrm{R}_{\text {sample }}-\mathrm{R}_{\text {standard }}}{\mathrm{R}_{\text {standard }}} \times 1,000
$$

where $R_{\text {sample }}=\begin{aligned} & \text { ratio of isotopic concentration }\left({ }^{18} \mathrm{O} /{ }^{16} \mathrm{O}, \mathrm{D} / \mathrm{H},{ }^{13} \mathrm{C} /{ }^{12} \mathrm{C}\right) \text { of } \\ & \text { the sample, and }\end{aligned}$ $\mathrm{R}_{\text {standard }}=$ ratio of isotopic concentration of the standard SMOW (standard mean ocean water), for oxygen and hydrogen; for carbon the standard is Belemnites from the Peedee formation of South Carolina (PDB). 


\section{Mineral Formulas}

Name

Calcite

Ilmenite

Plagioclase

Potassium feldspar

Pyrite

Pyroxene

Quartz

Siderite
Formula

$\mathrm{CaCO}_{3}$

$\mathrm{FeTiO}_{3}$

$$
\begin{gathered}
\mathrm{Ca}_{0.2} \stackrel{\mathrm{Na}}{0.8}_{\mathrm{KAlSi}_{3} \mathrm{O}_{8}}^{\mathrm{Al}_{1.2} \mathrm{Si}_{2.8}{ }^{\mathrm{O}_{8}}} \\
\mathrm{FeS}_{2}
\end{gathered}
$$

$\mathrm{ABSi}_{2} \mathrm{O}_{6}$ where

$\mathrm{A}$ is chiefly $\mathrm{Mg}, \mathrm{Fe}^{+^{2}}, \mathrm{Ca}, \mathrm{Na}$ and

$\mathrm{B}$ is chiefly $\mathrm{Mg}, \mathrm{Fe}^{+^{2}}$, and $\mathrm{Al}$

$\mathrm{SiO}_{2}$

$\mathrm{FeCO}_{3}$ 


\section{Lithologic Logs of Wells and Boreholes}

The location of wells and boreholes is shown on plate 1 .

\begin{tabular}{lccc} 
Materials & $\begin{array}{c}\text { Thickness } \\
\text { (feet) }\end{array}$ & $\begin{array}{c}\text { Depth } \\
\text { (feet) }\end{array}$ & $\begin{array}{c}\text { Altitude } \\
\text { (feet) }\end{array}$ \\
\hline
\end{tabular}

EDA. 25S/13W-05CBB01. Altitude 15 feet. Drilled by Bill Miller Well

Drilling, 1984 .

Sand, light gray, medium

Sand, silt and wood

Sand, gray, medium

Sand and clay

Sand, gray, medium

Sand, gray, coarse, shells

Claystone, gray

$\begin{array}{rrr}45 & 45 & -30 \\ 18 & 63 & -48 \\ 27 & 90 & -75 \\ 30 & 120 & -105 \\ 43 & 163 & -148 \\ 16 & 179 & -164 \\ 5 & 184 & -169\end{array}$

W46. 24S/13W-32DCB01. Altitude 17 feet. Drilled by Casey Jones Well Drilling, 1968. Compiled by Robison (1973).

Sand, fine

20

Sand, light blue and gray, fine

Sand, light gray

Sand, very light gray, coarse

22

5

Sand, light brown, coarse

16

17

14

Sand, coarse, clay and shells

Sandstone and she11s

24

Sandstone, grave1, and shells

Sand, gray

Clay, sand, coarse, and shells

Sand, very coarse, small gravel and shells

Sand, gray, coarse

Sand, dark gray, coarse, shells, shale

Sand, with wood, shells, and clay

Sand, very coarse, and small gravel

Clay and coarse sand, wood and shells

Shale and clay

$\begin{array}{rrr}20 & 20 & -3 \\ 22 & 42 & -25 \\ 5 & 47 & -30 \\ 16 & 63 & -46 \\ 17 & 80 & -63 \\ 14 & 94 & -77 \\ 24 & 118 & -101 \\ 7 & 125 & -108 \\ 6 & 131 & -114 \\ 4 & 135 & -118 \\ 3 & & -121 \\ 7 & 138 & -128 \\ 15 & 145 & -143 \\ 13 & 160 & -156 \\ 2 & 173 & -158 \\ 9 & 175 & -167 \\ 6 & 184 & -173\end{array}$


P46Y. 24S/13W-32CCA01. Altitude 9 feet. Drilled by Casey Jones Well Drilling, 1968. Compiled by Robison (1973).

Sand, fine

Sand, blue and gray

Sand, light gray

Sand, gray, shells

Sand, blue, coarse

Sand, gray, coarse, shells

Sand, gray, medium to coarse

Sand, gray, fine, packed, and very fine silt

Clay, blue-black, sticky

$\begin{array}{rrr}29 & 29 & -20 \\ 24 & 53 & -44 \\ 13 & 66 & -57 \\ 26 & 92 & -83 \\ 11 & 103 & -94 \\ 39 & 142 & -133 \\ 9 & 151 & -142 \\ 37 & & \\ 3 & 188 & -179 \\ & 191 & -182\end{array}$

SCP2C. 24S/13W-33DDB03. Altitude 22 feet. Drilled, 1961.

\section{Sand}

Clay, wood peat

Sand, gray, wood fragments

Sand, gray

Sand, clayey

Sand, fine, wood fragments

Sand with shells, medium

Sand, shells, and rock fragments

Sand and rock fragments

Sand and peaty clay

Claystone

$\begin{array}{rrr}24 & 24 & -2 \\ 11 & 35 & -13 \\ 5 & 40 & -18 \\ 2 & 42 & -20 \\ 12 & 54 & -32 \\ 14 & 68 & -46 \\ 27 & 95 & -73 \\ 14 & 109 & -87 \\ 16 & 125 & -103 \\ 9 & 134 & -112 \\ 8 & 142 & -120\end{array}$

W48. 24S/13W-33DBC01. Altitude 26 feet. Drilled, 1957. Compiled by Robison (1973).

Sand, fine, with thin bands of clay

Sand and shells, coarse

45

20

25

Sand and shells, medium to coarse

Sand and shells, coarse

No sample

Sand and she11s, coarse

Sand and shells, medium to fine

Sand, medium to fine, with thin

clay layers

Clay, shale, or siltstone
10

5

15

5

13

4

45
65
90
100
105
120
125
138
142

$-39$

$-64$

$-74$

$-79$

$-94$

$-99$

$-112$

$-116$ 
W45. 24S/13W-32ACC01. A1titude 18 feet. Drilled by Casey Jones Well Drilling, 1968. Compiled by Robison (1973).

Sand, yellow, fine

Sand, light-green, fine

Sand, brown, medium

Sand, brown, medium, and she11s

Sand, brown, medium

Sand, brown, medium, and shells

Sand, brown, medium

Sand, gray, medium, and some small grave1

Sand, gray, medium, gravel and she11s

Clay, dark-gray, sticky

$\begin{array}{rrr}25 & 25 & -7 \\ 10 & 35 & -17 \\ 15 & 50 & -32 \\ 22 & 72 & -54 \\ 11 & 83 & -65 \\ 5 & 88 & -70 \\ 22 & 110 & -92 \\ 60 & 170 & -152 \\ 15 & & \\ 5 & 185 & -167 \\ & 190 & -172\end{array}$

BB8. 24S/13W-32ADD01. Altitude 19 feet. Drilled by U.S. Geological Survey, 1970. Compiled by Robison (1973).

Sand, beige, fine to medium

$\begin{array}{rrr}2 & 2 & 17 \\ 6 & 8 & 11 \\ 5 & 13 & 6 \\ 92 & 105 & -86\end{array}$

W49. 24S/13W-33ACD01. Altitude 23 feet. Drilled, 1957. Compiled by Robison (1973).

Sand, fine, with thin bands of clay 35

Sand with shells, fine

20

35

$-12$

Sand, coarse, few thin clay bands near top

15

55

$-32$

Sand with shells, medium to coarse

Sand with shells, coarse

70

25

95

$-72$

Sand with shells, medium to fine

100

$-77$

5

105

$-82$

Sand with shells, medium to fine, with thin clay layers

25

130

$-107$

Sand, coarse, shell and rock fragments

Clay, shale, or siltstone
$6 \quad 136$

$-113$

4 
W47. 24S/13W-33ACC01. Altitude 24 feet. Drilled, 1957. Compiled by Robison (1973).

No sample

Sand, fine, with thin bands of clay

Sand with shells, coarse

Sand, medium to coarse

Sand with shells, medium to coarse

Sand with shells, coarse

Sand with she11s, medium to fine

Sand with shells, medium to fine with thin clay layers
Sand, coarse; shale and rock fragments

Clay, shale, or siltstone

$\begin{array}{rrr}20 & 20 & 4 \\ 35 & 55 & -31 \\ 5 & 60 & -36 \\ 15 & 75 & -51 \\ 10 & 85 & -61 \\ 10 & 95 & -71 \\ 25 & 120 & -96 \\ & & \\ 15 & 135 & -111 \\ 3 & 138 & -114 \\ 7 & 145 & -121\end{array}$

SCP4C. 24S/13W-33DAA04. A1titude 25 feet. Drilled, 1961.

$\begin{array}{rrr}25 & 25 & 0 \\ 1 & 26 & -1 \\ 14 & 40 & -15 \\ 15 & 55 & -30 \\ 2 & 57 & -32 \\ 6 & 63 & -38 \\ 6 & 69 & -44 \\ 5 & 74 & -49 \\ 7 & 81 & -56 \\ 17 & 98 & -73 \\ 7 & 105 & -80 \\ 4 & 109 & -84 \\ 9 & 118 & -93 \\ 6 & 124 & -99 \\ 11 & 135 & -108 \\ 12 & 147 & -122\end{array}$

P45. 24S/13W-32BDC01. Altitude 13 feet. Drilled by Casey Jones Well Drilling, 1968. Compiled by Robison (1973).

Sand, fine

Sand, gray, some rock

Sand, gray

Sand, gray, and shells

Sand, brown, coarse

Sand, some shells

Sand, brown

Sand, brown, and shells

Sand, gray, and shells

Clay, dark-brown

$\begin{array}{rr}37 & -24 \\ 47 & -34 \\ 57 & -44 \\ 72 & -59 \\ 87 & -74 \\ 90 & -77 \\ 97 & -84 \\ 127 & -114 \\ 160 & -147 \\ 170 & -157\end{array}$


SCP6C. 24S/13W-34BCB03. Altitude 25 feet. Drilled, 1961.

$\begin{array}{lrrr}\text { Sand, white } & 30 & 30 & -5 \\ \text { Sand, gray silt } & 6 & 36 & -11 \\ \text { Sand and silt } & 5 & 41 & -16 \\ \text { Sand, clayey } & 3 & 44 & -19 \\ \text { Clay } & 4 & 48 & -23 \\ \text { Sand, clayey } & 13 & 61 & -36 \\ \text { Sand, clayey, some wood fragments } & 3 & 64 & -39 \\ \text { Sand, clayey, shells and wood fragments } & 28 & 92 & -67 \\ \text { Sand, clayey } & 6 & 98 & -73 \\ \text { Sandy clay } & 4 & 102 & -77 \\ \text { Sand, clayey, shell fragments } & 21 & 123 & -98 \\ \text { Sand, clay, rocks } & 3 & 126 & -101 \\ \text { Sandy clay } & 8 & 134 & -109 \\ \text { Sand, rock fragments, she1ls, clay } & 5 & 139 & -114 \\ \text { Claystone } & 12 & 151 & -126\end{array}$

W50. 24S/13W-33ADB01. Altitude 25 feet. Drilled by L. R. Gaudio Drilling Co., 1960. Compiled by Robison (1973).

Sand, medium, with $1 / 2$-in. clay bed at $45 \mathrm{ft}$ and $50 \mathrm{ft}$, shell fragments at $70 \mathrm{ft}$ and $95 \mathrm{ft}$

$\begin{array}{rrrr} & 102 & 102 & -77 \\ & & & \\ & 7 & 109 & -84 \\ \mathrm{ft} & 31 & 140 & -115 \\ & 2 & 142 & -117 \\ & 8 & 150 & -125\end{array}$

Sand, fine, and shel1 fragments, 1-in.

clay layer at $109 \mathrm{ft}$

W44. 24S/13W-32ABD01. Altitude 22 feet. Drilled by Casey Jones We11 Drilling, 1968. Log interpreted by authors from available drill cuttings.

Sand, brown, medium - fine

$50 \quad 50-28$

Sand, brown, some shell fragments, medium-fine

$\begin{array}{rrr}10 & 60 & -38 \\ 130 & 190 & -168 \\ 5 & 195 & -173 \\ 1 & 196 & -174\end{array}$

$\begin{array}{llll}\text { Sand, clayey, gray, large she11 fragments } & 5 & 195 & -173 \\ \text { Claystone } & 1 & 196 & -174\end{array}$

BB2. 24S/13W-33BAA02. Altitude 22 feet. Drilled by U.S. Geological Survey, 1970. Compiled by Robison (1973).

Sand, brown, fine to medium Sand, beige, fine to medium Sand, gray, fine to medium
7

5

113
$1 \frac{7}{12}$

125
15

10

$-103$ 
W51. 24S/13W-28DDD01. Altitude 21 feet. Drilled by L. R. Gaudio Drilling Co., 1960. Compiled by Robison (1973).

Sand, medium, with 1/2-in. clay layer at $40 \mathrm{ft}$, and shell fragments at $45 \mathrm{ft}$

Sand with shells

Sand, medium

Sand with shells

Sand, shells, and clay

Sand, fine, some shells

Sand, medium, some she11s

Sand, fine

Sand, medium, and shells

Sand, medium, clay, she11s, and wood

Rock, soft

$\begin{array}{rrr}55 & 55 & -34 \\ 5 & 60 & -39 \\ 20 & 80 & -59 \\ 7 & 87 & -66 \\ 6 & 93 & -72 \\ 27 & 120 & -99 \\ 10 & 130 & -109 \\ 5 & 135 & -114 \\ 21 & 156 & -135 \\ 8 & 164 & -143 \\ 11 & 175 & -154\end{array}$

SCP11C. 24S/13W-27CCA03. A1titude 25 feet. Drilled, 1961.

Sand, white

Sand, clayey

Sand, clayey, gray

Clay

Sand, clayey

Clay

Sandy clay

Sandy clay with shells

Sand, clayey

Sand with she11 fragments

Sand, she11s, and wood fragments

Sand and shells

Clay

Sandy clay

Clay

Sandy clay with shells

Sand, clay with shells

Clays tone

$\begin{array}{rrr}25 & 25 & 0 \\ 5 & 30 & -5 \\ 12 & 42 & -17 \\ <.5 & 42 & -17 \\ 2 & 44 & -19 \\ 7 & 51 & -26 \\ 5 & 56 & -31 \\ <.5 & 56 & -31 \\ 9 & 65 & -40 \\ 16 & 81 & -56 \\ 7 & 88 & -63 \\ 18 & 106 & -81 \\ 10 & 116 & -91 \\ 5 & 121 & -96 \\ 8 & 133 & -108 \\ 22 & 155 & -130 \\ 1 & 156 & -131 \\ 20 & 176 & -151\end{array}$

W43. 24S/13W-29DDA01. A1titude 20 feet. Drilled by Casey Jones Well Drilling, 1968. Compiled by Robison (1973).

Sand, yellow, fine

Sand, yellow, fine, with vegetation

Sand, yellow, fine

13

$6 \quad 6$

$6 \quad 12$

14

13

Sand, light green, fine, and silt

Sand, dark gray, medium

Sand, dark gray, medium, and shells

10

Sand, dark gray, medium

27

108

135

Sand, dark gray, medium, clay and gravel

42

177

clay, blue, soft, sticky, and shells 
HF2H2 (P44). 24S/13W-32BAA01. Altitude 12 feet. Drilled by Casey Jones We11 Drilling, 1968. Log interpreted by authors from available drill cuttings.

Sand, yellow gray, fine

Sand, yellow gray, fine-medium

Sand, yellow brown, fine

Sand with shells, yellow brown, fine-medium

Sand with shells, yellow brown, fine-medium

Sand, yellow brown, fine-medium

Claystone, gray

$\begin{array}{rrr}30 & 30 & -18 \\ 20 & 50 & -38 \\ 20 & 70 & -58 \\ 10 & 80 & -68 \\ 50 & & \\ 20 & 130 & -118 \\ 9 & 150 & -138 \\ & 159 & -147\end{array}$

W52. 24S/13W-28DDA01. Altitude 22 feet. Drilled by L. R. Gaudio Drilling Co., 1960. Compiled by Robison (1973).

Sand, medium

$\begin{array}{rrr}78 & 78 & -56 \\ 14 & 92 & -70 \\ 6 & 98 & -76\end{array}$

Clay

Sand, fine, some shells, clay and wood at $140 \mathrm{ft}$

$\begin{array}{rll}42 & 140 & -118 \\ 7 & 147 & -125 \\ 40 & 187 & -165 \\ 24 & 211 & -189 \\ 1 & 212 & -190\end{array}$

Sand, medium

Sand, medium shells, and wood

Sand, clay, shells, and wood

Rock, soft
$-70$

$-125$

165

$-190$

P43. 24S/13W-29DBD01. Altitude 17 feet. Drilled by Casey Jones Well Drilling, 1968. Compiled by Robison (1973).

$\begin{array}{lrrr}\text { Sand, fine } & 19 & 19 & -2 \\ \text { Sand, blue } & 3 & 22 & -5 \\ \text { Sand, gray, and shells } & 28 & 50 & -33 \\ \text { Sand, gray } & 10 & 60 & -43 \\ \text { Sand, dark gray, coarse } & 15 & 75 & -58 \\ \text { Sand, gray, coarse, and shells } & 20 & 95 & -78 \\ \text { Sand, gray, gravel and shells } & 10 & 105 & -88 \\ \text { Sand, gray, and silt } & 40 & 145 & -128 \\ \text { Sand, light gray, coarse } & 10 & 155 & -138 \\ \text { Sand, gray, coarse } & 7 & 162 & -145 \\ \text { Sand, gray, very coarse } & 19 & 181 & -164\end{array}$


W53. 24S/13W-27CBB01. Altitude 23 feet. Drilled by Casey Jones We11 Drilling, 1968. Compiled by Robison (1973).

Sand, yellow, fine

Sand, green, fine

Sand, brown, coarse, and silt

Sand, fine, and silt, blue

Sand, coarse, and shells

Shelis and blue sand

Sand, blue, coarse, and shells

Sand, blue, coarse

Sand, blue, coarse, and shells

Sand, coarse, she11s, and pebbles

Clay, dark blue, sand, wood, and bark

Log

Clay, dark blue, sand and soft boulders

Sand, silt, rotten bark, and wood

Clay, blue, soft, sticky

$\begin{array}{rrr}20 & 20 & 3 \\ 19 & 39 & -16 \\ 3 & 42 & -19 \\ 3 & 45 & -22 \\ 5 & 50 & -27 \\ 2 & 52 & -29 \\ 13 & 65 & -42 \\ 10 & 75 & -52 \\ 20 & 95 & -72 \\ 6 & 101 & -78 \\ 3 & 104 & -81 \\ 3 & 107 & -84 \\ 5 & 112 & -89 \\ 8 & 120 & -97 \\ 8 & 128 & -105\end{array}$

W42. 24S/13W-28BCC01. Altitude 22 feet. Drilled by Casey Jones We11 Drilling, 1968. Compiled by Robison (1973).

Sand, brown, wood

Sand, blue, fine

Sand, brownish-gray, medium

Sand, coarse, wood and shells

Sand, dark bluish-gray, wood and peat

Sand, dark bluish-gray

Sandstone, gray, hard

$\begin{array}{rrr}26 & 26 & -4 \\ 44 & 70 & -48 \\ 22 & 92 & -70 \\ 25 & 117 & -95 \\ 2 & 119 & -97 \\ 15 & 134 & -112 \\ 6 & 140 & -118\end{array}$

W54. 24S/13W-27BCC01. Altitude 23 feet. Drilled by Casey Jones We11 Drilling, 1968. Log interpreted by authors from available drill cuttings.

Sand, yellow-brown, fine-medium $40 \quad 40$

Sand with shells, yellow-gray, medium - fine

$\begin{array}{lll}15 & 55 & -32\end{array}$

Sand with shells, yellow-gray, fine-medium

35

Sand with shells, yellow-gray, fine-medium

Clay, silty, gray 
P42. 24S/13W-29ABD01. Altitude 18 feet. Drilled by Casey Jones Well Drilling, 1968. Compiled by Robison (1973).

Sand, fine

Sand, blue

Sand, gray

Sand, dark gray, coarse

Sand, dark gray, shells

Sand, dark gray, coarse

Sand, black, coarse, and shells

Sand, dark gray, shale and sandstone

Shale, gray, sand and clay

Sand, blue, very coarse

Shale and clay

$\begin{array}{rrr}15 & 15 & 3 \\ 20 & 35 & -17 \\ 8 & 43 & -25 \\ 7 & 50 & -32 \\ 28 & 78 & -60 \\ 12 & 90 & -72 \\ 8 & 98 & -80 \\ 4 & 102 & -84 \\ 24 & 126 & -108 \\ 1 & 127 & -109 \\ 17 & 144 & -126\end{array}$

P55. 24S/13W-27BAB01. Altitude 24 feet. Drilled by Casey Jones Well Drilling, 1968. Compiled by Robison (1973).

Sand, yellow, fine

Sand, yellow and gray

Sand, brown

Sand, clay, and silt, blue

Clay, brown, and vegetation

Sand, blue, coarse

Sand, gray, coarse, shells

Sand, gray, very coarse, shells

Clay and shale

$\begin{array}{rrr}14 & 14 & 10 \\ 7 & 21 & 3 \\ 10 & 31 & -7 \\ 14 & 45 & -21 \\ 3 & 48 & -24 \\ 23 & 71 & -47 \\ 13 & 84 & -60 \\ 23 & 107 & -83 \\ 15 & 122 & -98\end{array}$

W55. 24S/13W-27BBC01. Altitude 24 feet. Drilled by Casey Jones Well Drilling, 1968. Log interpreted by authors from available drill cuttings.

Sand, light-colored

Sand, yellow-gray

Sand, yellow-gray, wood fragments

20

35

Sand, yellow-gray

Sand with shells, gray

Sand with shells, gray

Sand with large shell fragments, gray

Claystone

$\begin{array}{rrr}35 & 55 & -31 \\ 5 & 60 & -36 \\ 15 & 75 & -51 \\ 5 & 80 & -56 \\ 10 & 90 & -66 \\ 15 & 105 & -81 \\ 2 & 107 & -83\end{array}$


P54. 24S/13W-27BDB01. Altitude 18 feet. Drilled by Casey Jones Well

Drilling, 1968. Log interpreted by authors from available drill cuttings.

Sand, yellow-gray

Sand with silt and clay, yellow-gray

Sand with silt and clay, yellow-gray

Sand, gray

Sand with she11s

Silt and clay with shells

Silt and clay with shells

Sand with shells, gray

Sand with shells, gray

Silt and clay (claystone) with shells

$\begin{array}{rrr}10 & 10 & 8 \\ 10 & 20 & -2 \\ 40 & 60 & -42 \\ 10 & 70 & -52 \\ 10 & 80 & -62 \\ 7 & 87 & -69 \\ 3 & 90 & -72 \\ 1 & 91 & -73 \\ 29 & 120 & -102 \\ 10 & 130 & -112\end{array}$

SP1. 24S/13W-28AAA01. Altitude 18 feet. Drilled by U.S. Geological Survey, 1970. Compiled by Robison (1973).

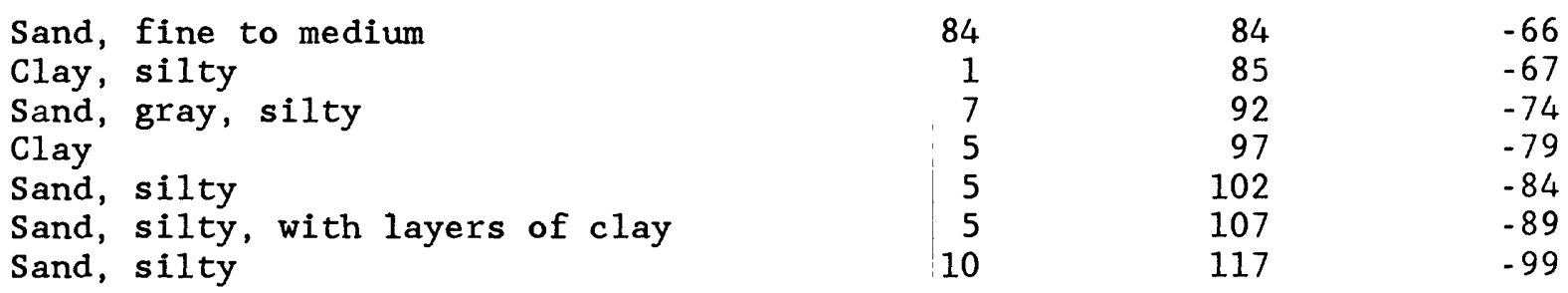

W41. 24S/13W-21CDC01. Altitude 21 feet. Drilled by Casey Jones Well

Drilling, 1968. Compiled by Robison (1973).

Sand, blue

Sand, gray

Sand with she11s, gray

Sand, very dark gray

Sand, gray, coarse

Sand, light gray

Sand, gray

Sand, dark gray

Sand, dark gray, shells and wood

Sandstone, gray

Shale, brown, hard

Shale, dark brown, hard

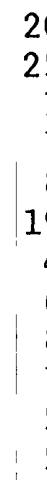

$\begin{array}{rr}20 & 1 \\ 45 & -24 \\ 46 & -25 \\ 53 & -32 \\ 61 & -40 \\ 80 & -59 \\ 84 & -63 \\ 90 & -69 \\ 98 & -77 \\ 105 & -84 \\ 110 & -89 \\ 115 & -94\end{array}$

P56. 24S/13W-22CDC01. Altitude 20 feet. Drilled by Casey Jones Well

Drilling, 1968. Compiled by Robison (1973).

Sand, brown

Mud, black

Sand, blue, with silt

Sand, blue, fine

Sand, blue, coarse, few shells

Shale

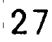

2

13

56

10

17
27

29

42

98

108

125
8

52

$-62$

72

73

$-112$ . 
W56. 24S/13W-22CCD01. Altitude 26 feet. Drilled by Casey Jones We11 Drilling, 1968. Compiled by Robison (1973).

Sand, fine

Sand, light blue, with thin layer of vegetation

Sand, light blue

Sand, blue

Sand, gray

Sand, gray, coarse, and shells

Sand, gray, and shells

Shells, clay, and mud

Clay
20

2

24

14

20

15

9

1

11
20

22

46

60

80

95

104

105

116
6

4

$-20$

$-34$

$-54$

$-69$

$-78$

$-79$

$-90$

P41. 24S/13W-20DCB01. Altitude 18 feet. Drilled by Casey Jones Well Drilling, 1968. Compiled by Robison (1973).

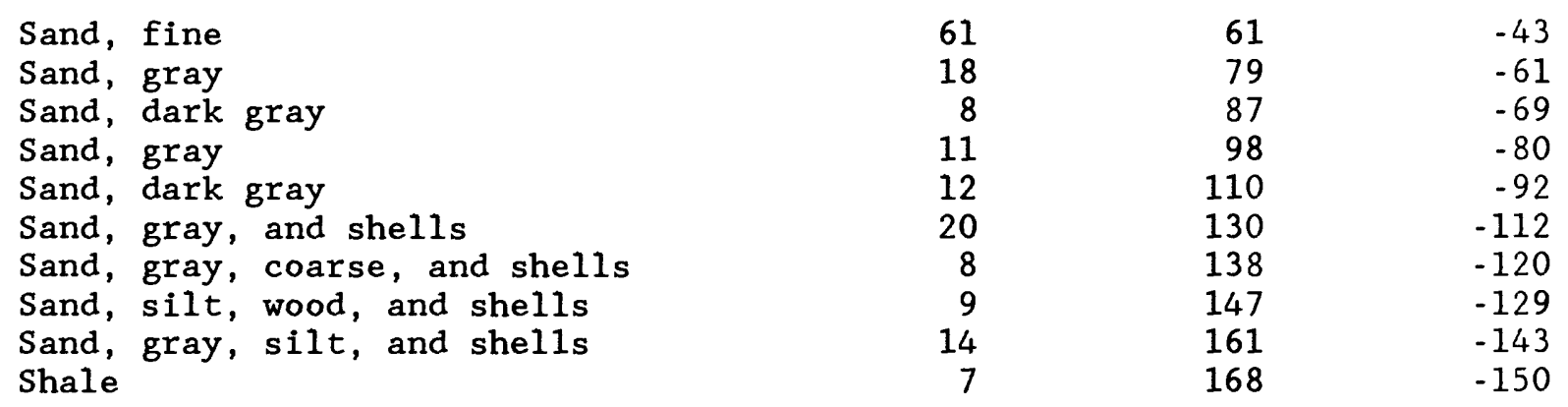

W57. 24S/13W-22CBD01. Altitude 23 feet. Drilled by Casey Jones We11 Drilling, 1968. Compiled by Robison (1973) and $\log$ interpretation modified by authors based on available drill cuttings.

Sand, brown and yellow, fine

Peat

Sand, brown and blue

Sand, blue, medium to fine

Sand, blue, fine, and clay

Sand, blue, coarse

Sand, blue, coarse, with shells

Sand, blue, medium, shells

Sand, blue, with wood and shells

Sand, blue, coarse, shells

Clays tone

$\begin{array}{rll}29 & 29 & -6 \\ 0.5 & 29.5 & -6.5 \\ 3.5 & 33 & -10 \\ 17 & 50 & -27 \\ 1 & 51 & -28 \\ 14 & 65 & -42 \\ 3 & 68 & -45 \\ 32 & 100 & -77 \\ 2 & 102 & -79 \\ 7 & 109 & -86 \\ 10 & 119 & -96\end{array}$


P58. 24S/13W-22CAA01. A1titude 20 feet. Drilled by Casey Jones We11

Drilling, 1968. Compiled by Robison (1973) and log interpretation modified by authors based on available drill cuttings.

\section{Sand}

Vegetation

Sand, dark brown

Sand, light blue

Sand and clay

Sand and silt, dark gray

Sand, black and white

Sand, black, with some white

Sand, gray, coarse, shells

Sand, gray, very coarse, with shells

Sand and she11s

Sand, gray, coarse, shells

Humus and fine gray sand with shells

Sand, gray, and shells

Clay and shale

$\begin{array}{rrr}21 & 21 & -1 \\ 1 & 22 & -2 \\ 1 & 23 & -3 \\ 7 & 30 & -10 \\ 5 & 35 & -15 \\ 8 & 43 & -23 \\ 17 & 60 & -40 \\ 5 & 65 & -45 \\ 25 & 90 & -70 \\ 10 & 100 & -80 \\ 10 & 110 & -90 \\ 14 & 124 & -104 \\ 4 & 128 & -108 \\ 12 & 140 & -120 \\ 6 & 146 & -126\end{array}$

W58. 24S/13W-22BDC01. Altitude 24 feet. Drilled by Casey Jones Well Drilling, 1968. Compiled by Robison (1973).

Sand, brown, fine 19

Sand, brown, fine, and vegetation : 6

19

Sand, brown, fine 10

Sand, blue, coarse, with a little silt 15

Sand, blue, medium 11

Sand, gray

Shells and coarse sand

11
9

Sand, gray, coarse, shells, trace of silt 14

Sand, coarse, small amount of gravel

Sand with small shells

Sand with wood and shells, gray

Sand with many she1ls, light gray

Sand, gray, coarse, and some shells

Sand, light blue, and shells

Sand, coarse, and clam shells with wood

Claystone

$\begin{array}{rrr}9 & 19 & 5 \\ 6 & 25 & -1 \\ 0 & 35 & -11 \\ 5 & 50 & -26 \\ 1 & 61 & -37 \\ 9 & 70 & -46 \\ 1 & 71 & -47 \\ 4 & 85 & -61 \\ 4 & 89 & -65 \\ 5 & 94 & -70 \\ 2 & 96 & -72 \\ 4 & 100 & -76 \\ 0 & 110 & -86 \\ 5 & 115 & -91 \\ 2 & 117 & -93 \\ 8 & 125 & -101\end{array}$

W59. 24S/13W-22BAD01. Altitude 24 feet. Drilled by Corva11is Drilling Co., 1979.

Sand, brown

Sand, light blue

Sand with clay, light blue

Sand, blue, coarse

Sand, pebbles, shells

Sand, blue, coarse shell fragments

Clay, blue, sandy

$\begin{array}{rrr}32 & 32 & -8 \\ 24 & 56 & -32 \\ 8 & 64 & -40 \\ 23 & 87 & -63 \\ 8 & 95 & -71 \\ 35 & 130 & -106 \\ 1 & 131 & -106\end{array}$


W60. 24S/13W-15CDD01. Altitude 64 feet. Drilled by Corvallis Drilling Co., 1980 .

Sand, light brown

Sand, brown

Sand, brown, wood fragments

Sand, gray, wood fragments

Sand, gray

Clay, sandy, blue-gray

Sand, gray

Sand with clay, gray

Sand, gray, medium

Sand, gray, coarse

Clay, gray

$\begin{array}{rrr}20 & 20 & 44 \\ 32 & 52 & 8 \\ 6 & 58 & 6 \\ 9 & 67 & -3 \\ 16 & 83 & -19 \\ 17 & 100 & -36 \\ 8 & 108 & -44 \\ 1 & 109 & -45 \\ 28 & 137 & -73 \\ 16 & 153 & -89 \\ 1 & 154 & -90\end{array}$

Radar Cluster G9. 24S/13W-15ACD01. Altitude 23 feet. Drilled for Pacific Power and Light Co., 1957. Compiled by Robison (1973).

Soil and sand

Sand, gray

Sand, brown and gray; hard silt streak at 22 feet

Sand, blue-gray; hard streaks at 62 , 68 , and 75 feet

Clay, sandy

Clay, dark, shalelike partings

$\begin{array}{rrr}2 & 2 & 21 \\ 18 & 20 & 3\end{array}$

$\begin{array}{lll}10 & 30 & -7\end{array}$

$48 \quad 78-55$

$5 \quad 83 \quad-60$

Hauser No. 1. 24S/13W-10DDD01. Altitude 35 feet. Drilled for Pacific Power and Light Co., 1957.

Sand, light gray to tan, fine to medium; some iron staining

Sand, dark blue-gray, carbonaceous

Clay, black, with lignite

Clay and red-brown micaceous sandstone with chlorite and limonite

Shale, gray-black

$\begin{array}{rrr}65 & 65 & -30 \\ 13 & 78 & -43 \\ 3 & 81 & -46 \\ & & \\ 3 & 84 & -49 \\ 4 & 88 & -53\end{array}$

SN6. 24S/13W-16CCC04. Altitude 15 feet. Drilled by U.S. Geological Survey, 1987.

Sand, reddish-brown

Sand, gray

Sand, gray

Sand, reddish-brown and gray mixed

Sand, gray

Sand, gray, shell fragments

$\begin{array}{rrr}3 & 3 & 12 \\ 3 & 6 & 9 \\ 79 & 85 & -70 \\ 5 & 90 & -75 \\ 5 & 95 & -80 \\ 0.5 & 95.5 & -80.5\end{array}$


BL6. 24S/13W-09DBC03. Altitude 15 feet. Drilled by U.S. Geological Survey, 1987.

Sand, light brown

Sand, gray

Sand, gray, some shells

Clayey sand, claystone

$\begin{array}{rrr}18 & 18 & -3 \\ 77 & 95 & -80 \\ 30 & 125 & -110 \\ 1 & 126 & -111\end{array}$

200C. 24S/13W-10CAB03. Altitude 35 feet. Drilled for Pacific Power and Light Co., 1957. Compiled by Robison (1973).

Sand, consolidated and slightly con49 49 $-14$ solidated

Sand, consolidated and slightly consolidated; thin clay lenses to $1 / 2$-in. thick

Sand

Sand with clay fragments to $1 / 2-$ in. diameter

Sand and dark gray-green clay

Sand with clay fragments to $3 / 4-i n$. diameter

Sand with many clay fragments to $1 / 2-$ in diameter

Sand with few small clay fragments

Sand

Sand with trace of mica; few fossils

Sand

Sand; trace of clay and claystone fragments

Sand with mudstone fragments

Sand with pebbles of sandstone, siltstone, and chert

Clay and mudstone, dark brown

Claystone, dark gray, fine

4

2

3

2

3

3

6

4

14

3

9

1

14

19
53

57

59

62

64

\section{7}

70

76

80

94

97

106

107

121

140
$-18$

$-22$

$-24$

$-29$

$-32$

$-35$

$-41$

$-45$

$-59$

$-62$

$-71$

$-72$

$-86$

$-105$

201. 24S/13W-09CAB01. Altitude 10 feet. Drilled for Pacific Power and Light Co., 1957. Compiled by Robison (1973).

Sand, unconsolidated

Sand, unconsolidated and semiconsolidated

Sand with trace of clay

Sand

Sand with shell fragments

Sand with claystone fragments

Sand

Sand with few tiny, rounded shale fragments

Sand with traces of mica and shells

Siltstone and mudstone, consolidated

40
30
10
3
14
13
16
22

40

30

5

10

3

2

14

13

16

22

$\begin{array}{rr}40 & -30 \\ 70 & -60 \\ 75 & -65 \\ 85 & -75 \\ 88 & -78 \\ 90 & -80 \\ 104 & -94 \\ 117 & -107 \\ 133 & -123 \\ 155 & -145\end{array}$


SL5. 23S/13W-33DDD01. A1titude 15 feet. Drilled by U.S. Geological Survey, 1987.

Sand, reddish-brown

$\begin{array}{rrr}2 & 2 & 13 \\ 73 & 75 & -60 \\ 47 & 122 & -107 \\ 1 & 123 & -108\end{array}$

Sand, gray

Sand, gray, she11s

Sandy clay, wood fragments

123

$-108$

203. 23S/13W-34CBB01. Altitude 11 feet. Drilled for Pacific Power and Light Co., 1957. Compiled by Robison (1973).

Sand, unconsolidated

Sand, gray, unconsolidated

Sand with few claystone fragments

Sand

Sand with shells and some claystone fragments

Sand with shells and some mica

Claystone, hard, and some interbedded siltstone

$\begin{array}{rrr}40 & 40 & -29 \\ 50 & 90 & -79 \\ 5 & 95 & -84 \\ 5 & 100 & -89 \\ 5 & 105 & -94 \\ 13 & 118 & -107 \\ 9 & 127 & -116\end{array}$

SL7. 23S/13W-34DBA04. Altitude 40 feet. Drilled by U.S. Geological Survey, 1987 .

Sand, brown

Sand, gray-brown

Sand, gray

Sand, trace of shells

Sand, gray

Claystone
28

2

40

0.5

24.5

0.5
28

30

70

70.5

95

95.5
12

10

$-30$

$-30.5$

$-55$

$-55.5$

S1H4. 23S/13W-27DDD04. Altitude 41 feet. Drilled by U.S. Geological Survey, 1986.

Sand, light gray, fine-medium

Sand, gray

Clays tone

$\begin{array}{rrr}10 & 10 & 31 \\ 82 & 92 & -51 \\ 1 & 93 & -52\end{array}$

S2H5. 23S/13W-27DAC05. Altitude 29 feet. Drilled by U.S. Geological Survey, 1987.

Sand, 1ight gray

Sand, light gray, roots

Sand, brown

Sand, gray

Sand, dark gray, fine

Clay, dark gray, some organic material

$\begin{array}{rrr}17 & 17 & 12 \\ 1 & 18 & 11 \\ 12 & 30 & -1 \\ 62 & 92 & -63 \\ 22 & 114 & -85 \\ 0.5 & 114.5 & -85.5\end{array}$


S4H5. 23S/13W-22DCD05. Altitude 16 feet. Drilled by U.S. Geological Survey, 1987.

Sand, brown

Sand, gray

Sand, gray-brown, some she11s

Sand, gray

Clay and sand, dark gray

10

22

18

68

6

$\begin{array}{rr}10 & 6 \\ 32 & -16 \\ 50 & -34 \\ 118 & -102 \\ 124 & -108\end{array}$

